\title{
Cassane Diterpenoids from the Pericarps of Caesalpinia
}

\section{bonduc}

Panpan Zhang, ${ }^{\dagger, \xi}$ Chunping Tang, ${ }^{\dagger, \star}$ Sheng Yao, ${ }^{\dagger, \ddagger}$ Changqiang Ke, ${ }^{\dagger, \ddagger}$ Ge Lin $, \stackrel{ }{\ddagger}, \S$

Hui-Ming Hua, ${ }^{*, \xi}$ and Yang Ye ${ }^{*, \dagger, \ddagger \perp}$

${ }^{\dagger}$ State Key Laboratory of Drug Research, and Natural Products Chemistry Department, Shanghai Institute of Materia Medica, Chinese Academy of Sciences, 555

Zu-Chong-Zhi Road, Zhangjiang Hi-Tech Park, Shanghai 201203, People's Republic of China

${ }^{\xi}$ Key Laboratory of Structure-Based Drug Design and Discovery, Ministry of

Education, Shenyang Pharmaceutical University, Shenyang 110016, Liaoning,

People's Republic of China

$\$$ Joint Research Laboratory for Promoting Globalization of Traditional Chinese

Medicines between Shanghai Institute of Materia Medica, Chinese Academy of

Sciences and The Chinese University of Hong Kong

${ }^{\S}$ School of Biomedical Sciences, Faculty of Medicine, The Chinese University of Hong

Kong, Hong Kong SAR

${ }^{\perp}$ School of Life Science and Technology, ShanghaiTech University, Shanghai, 201203, People's Republic of China 


\section{List of Content}

S1. The ${ }^{1} \mathrm{H}$ NMR (400 MHz, $\mathrm{CDCl}_{3}$ ) Spectrum of compound 1

S2. The ${ }^{13} \mathrm{C}$ NMR (400 MHz, $\mathrm{CDCl}_{3}$ ) Spectrum of compound $\mathbf{1}$

S3. The ${ }^{1} \mathrm{H}-{ }^{13} \mathrm{C}$ HMQC (400 MHz, $\mathrm{CDCl}_{3}$ ) Spectrum of compound 1

S4. The ${ }^{1} \mathrm{H}-{ }^{13} \mathrm{C} \mathrm{HMBC}\left(400 \mathrm{MHz}, \mathrm{CDCl}_{3}\right.$ ) Spectrum of compound $\mathbf{1}$

S5. The ${ }^{1} \mathrm{H}-{ }^{1} \mathrm{H}$ ROESY (400 MHz, $\mathrm{CDCl}_{3}$ ) Spectrum of compound 1

S6. The HR-ESI-MS spectrum of compound 1

S7. The IR Spectrum of compound 1

S8. The ${ }^{1} \mathrm{H}$ NMR (400 MHz, $\mathrm{CDCl}_{3}$ ) Spectrum of compound 2

S9. The ${ }^{13} \mathrm{C}$ NMR (100 MHz, $\mathrm{CDCl}_{3}$ ) Spectrum of compound 2

S10. The ${ }^{1} \mathrm{H}-{ }^{13} \mathrm{C}$ HMQC (400 MHz, $\mathrm{CDCl}_{3}$ ) Spectrum of compound 2

S11. The ${ }^{1} \mathrm{H}-{ }^{13} \mathrm{C}$ HMBC (400 MHz, $\mathrm{CDCl}_{3}$ ) Spectrum of compound 2

S12. The ${ }^{1} \mathrm{H}-{ }^{1} \mathrm{H}$ ROESY (400 MHz, $\mathrm{CDCl}_{3}$ ) Spectrum of compound 2

S13. The HR-ESI-MS spectrum of compound 2

S14. The IR Spectrum of compound 2

S15. The ${ }^{1} \mathrm{H}$ NMR (400 MHz, $\mathrm{CDCl}_{3}$ ) Spectrum of compound 3

S16. The ${ }^{13} \mathrm{C}$ NMR (100 MHz, $\mathrm{CDCl}_{3}$ ) Spectrum of compound $\mathbf{3}$

S17. The ${ }^{1} \mathrm{H}-{ }^{13} \mathrm{C}$ HMQC (400 MHz, $\mathrm{CDCl}_{3}$ ) Spectrum of compound 3

S18. The ${ }^{1} \mathrm{H}-{ }^{13} \mathrm{C}$ HMBC (400 MHz, $\mathrm{CDCl}_{3}$ ) Spectrum of compound 3

S19. The ${ }^{1} \mathrm{H}-{ }^{1} \mathrm{H}$ ROESY (400 MHz, $\mathrm{CDCl}_{3}$ ) Spectrum of compound 3

S20. The HR-ESI-MS spectrum of compound $\mathbf{3}$

S21. The IR Spectrum of compound 3

$\mathrm{S} 22$. The ${ }^{1} \mathrm{H}$ NMR (400 MHz, $\mathrm{CDCl}_{3}$ ) Spectrum of compound 4

S23. The ${ }^{13} \mathrm{C}$ NMR (100 MHz, $\mathrm{CDCl}_{3}$ ) Spectrum of compound 4

S24. The ${ }^{1} \mathrm{H}-{ }^{13} \mathrm{C}$ HMQC (400 MHz, $\mathrm{CDCl}_{3}$ ) Spectrum of compound 4

S25. The ${ }^{1} \mathrm{H}-{ }^{13} \mathrm{C}$ HMBC (400 MHz, $\mathrm{CDCl}_{3}$ ) Spectrum of compound 4

S26. The ${ }^{1} \mathrm{H}-{ }^{1} \mathrm{H}$ ROESY (400 MHz, $\mathrm{CDCl}_{3}$ ) Spectrum of compound 4

S27. The HR-ESI-MS spectrum of compound 4

S28. The IR Spectrum of compound 4

S29. The ${ }^{1} \mathrm{H}$ NMR (400 MHz, $\mathrm{CDCl}_{3}$ ) Spectrum of compound 5 
S30. The ${ }^{13} \mathrm{C}$ NMR (100 MHz, $\mathrm{CDCl}_{3}$ ) Spectrum of compound 5

S31. The ${ }^{1} \mathrm{H}-{ }^{13} \mathrm{C}$ HMQC ( $400 \mathrm{MHz}, \mathrm{CDCl}_{3}$ ) Spectrum of compound 5

S32. The ${ }^{1} \mathrm{H}-{ }^{13} \mathrm{C}$ HMBC (400 MHz, $\mathrm{CDCl}_{3}$ ) Spectrum of compound 5

S33. The ${ }^{1} \mathrm{H}-{ }^{1} \mathrm{H}$ ROESY $\left(400 \mathrm{MHz}, \mathrm{CDCl}_{3}\right)$ Spectrum of compound 5

S34. The HR-EI-MS spectrum of compound 5

S35. The IR Spectrum of compound 5

S36. The ${ }^{1} \mathrm{H}$ NMR (400 MHz, $\mathrm{CDCl}_{3}$ ) Spectrum of compound 6

S37. The ${ }^{13} \mathrm{C}$ NMR (100 MHz, $\mathrm{CDCl}_{3}$ ) Spectrum of compound 6

S38. The ${ }^{1} \mathrm{H}-{ }^{13} \mathrm{C}$ HMQC ( $400 \mathrm{MHz}, \mathrm{CDCl}_{3}$ ) Spectrum of compound 6

S39. The ${ }^{1} \mathrm{H}-{ }^{13} \mathrm{C} \mathrm{HMBC}\left(400 \mathrm{MHz}, \mathrm{CDCl}_{3}\right.$ ) Spectrum of compound 6

S40. The ${ }^{1} \mathrm{H}-{ }^{1} \mathrm{H}$ ROESY ( $400 \mathrm{MHz}, \mathrm{CDCl}_{3}$ ) Spectrum of compound 6

S41. The HR-EI-MS spectrum of compound 6

S42. The IR Spectrum of compound 6

S43. The ${ }^{1} \mathrm{H}$ NMR (400 MHz, $\mathrm{CDCl}_{3}$ ) Spectrum of compound 7

S44. The ${ }^{13} \mathrm{C}$ NMR (100 MHz, $\left.\mathrm{CDCl}_{3}\right)$ Spectrum of compound 7

S45. The ${ }^{1} \mathrm{H}-{ }^{13} \mathrm{C}$ HMQC ( $400 \mathrm{MHz}, \mathrm{CDCl}_{3}$ ) Spectrum of compound 7

S46. The ${ }^{1} \mathrm{H}-{ }^{13} \mathrm{C}$ HMBC ( $400 \mathrm{MHz}, \mathrm{CDCl}_{3}$ ) Spectrum of compound 7

S47. The ${ }^{1} \mathrm{H}-{ }^{1} \mathrm{H}$ ROESY ( $400 \mathrm{MHz}, \mathrm{CDCl}_{3}$ ) Spectrum of compound 7

S48. The HR-ESI-MS spectrum of compound 7

S49. The IR Spectrum of compound 7

S50. The ${ }^{1} \mathrm{H}$ NMR (400 MHz, $\mathrm{CDCl}_{3}$ ) Spectrum of compound 8

S51. The ${ }^{13} \mathrm{C}$ NMR $\left(100 \mathrm{MHz}, \mathrm{CDCl}_{3}\right)$ Spectrum of compound 8

S52. The ${ }^{1} \mathrm{H}-{ }^{13} \mathrm{C}$ HMQC ( $400 \mathrm{MHz}, \mathrm{CDCl}_{3}$ ) Spectrum of compound 8

S53. The ${ }^{1} \mathrm{H}-{ }^{13} \mathrm{C}$ HMBC (400 MHz, $\mathrm{CDCl}_{3}$ ) Spectrum of compound 8

S54. The ${ }^{1} \mathrm{H}-{ }^{1} \mathrm{H}$ ROESY (400 MHz, $\mathrm{CDCl}_{3}$ ) Spectrum of compound 8

S55. The HR-ESI-MS spectrum of compound $\mathbf{8}$

S56. The IR Spectrum of compound 8

S57. The ${ }^{1} \mathrm{H}$ NMR (400 MHz, $\mathrm{CDCl}_{3}$ ) Spectrum of compound 9

S58. The ${ }^{13} \mathrm{C}$ NMR $\left(100 \mathrm{MHz}, \mathrm{CDCl}_{3}\right)$ Spectrum of compound 9

S59. The ${ }^{1} \mathrm{H}-{ }^{13} \mathrm{C}$ HMQC (400 MHz, $\mathrm{CDCl}_{3}$ ) Spectrum of compound 9 
S60. The ${ }^{1} \mathrm{H}-{ }^{13} \mathrm{C}$ HMBC (400 MHz, $\mathrm{CDCl}_{3}$ ) Spectrum of compound 9

S61. The ${ }^{1} \mathrm{H}-{ }^{1} \mathrm{H}$ ROESY (400 MHz, $\mathrm{CDCl}_{3}$ ) Spectrum of compound 9

S62. The HR-EI-MS spectrum of compound 9

S63. The IR Spectrum of compound 9

S64. The ${ }^{1} \mathrm{H}$ NMR (400 MHz, $\mathrm{CDCl}_{3}$ ) Spectrum of compound 10

S65. The ${ }^{13} \mathrm{C}$ NMR (100 MHz, $\mathrm{CDCl}_{3}$ ) Spectrum of compound $\mathbf{1 0}$

S66. The ${ }^{1} \mathrm{H}-{ }^{13} \mathrm{C}$ HMQC (400 MHz, $\mathrm{CDCl}_{3}$ ) Spectrum of compound 10

S67. The ${ }^{1} \mathrm{H}-{ }^{13} \mathrm{C} \mathrm{HMBC}\left(400 \mathrm{MHz}, \mathrm{CDCl}_{3}\right.$ ) Spectrum of compound 10

S68. The ${ }^{1} \mathrm{H}-{ }^{1} \mathrm{H}$ ROESY (400 MHz, $\mathrm{CDCl}_{3}$ ) Spectrum of compound 10

S69. The HR-EI-MS spectrum of compound $\mathbf{1 0}$

S70. The IR Spectrum of compound $\mathbf{1 0}$

Table S1. Neuroprotective Effects of Selected Compounds isolated from C. bonduc against $\mathrm{H}_{2} \mathrm{O}_{2}$ Induced Neurotoxicity in SH-SY5Y Cells

Table S2. Neuroprotective Effects of Selected Compounds isolated from C. bonduc against $\mathrm{A} \beta_{25-35}$ Induced Neurotoxicity in SH-SY5Y Cells

Table S3. Neuroprotective Effects of Selected Compounds isolated from C. bonduc against OGD-Induced Neurotoxicity in SH-SY5Y Cells 


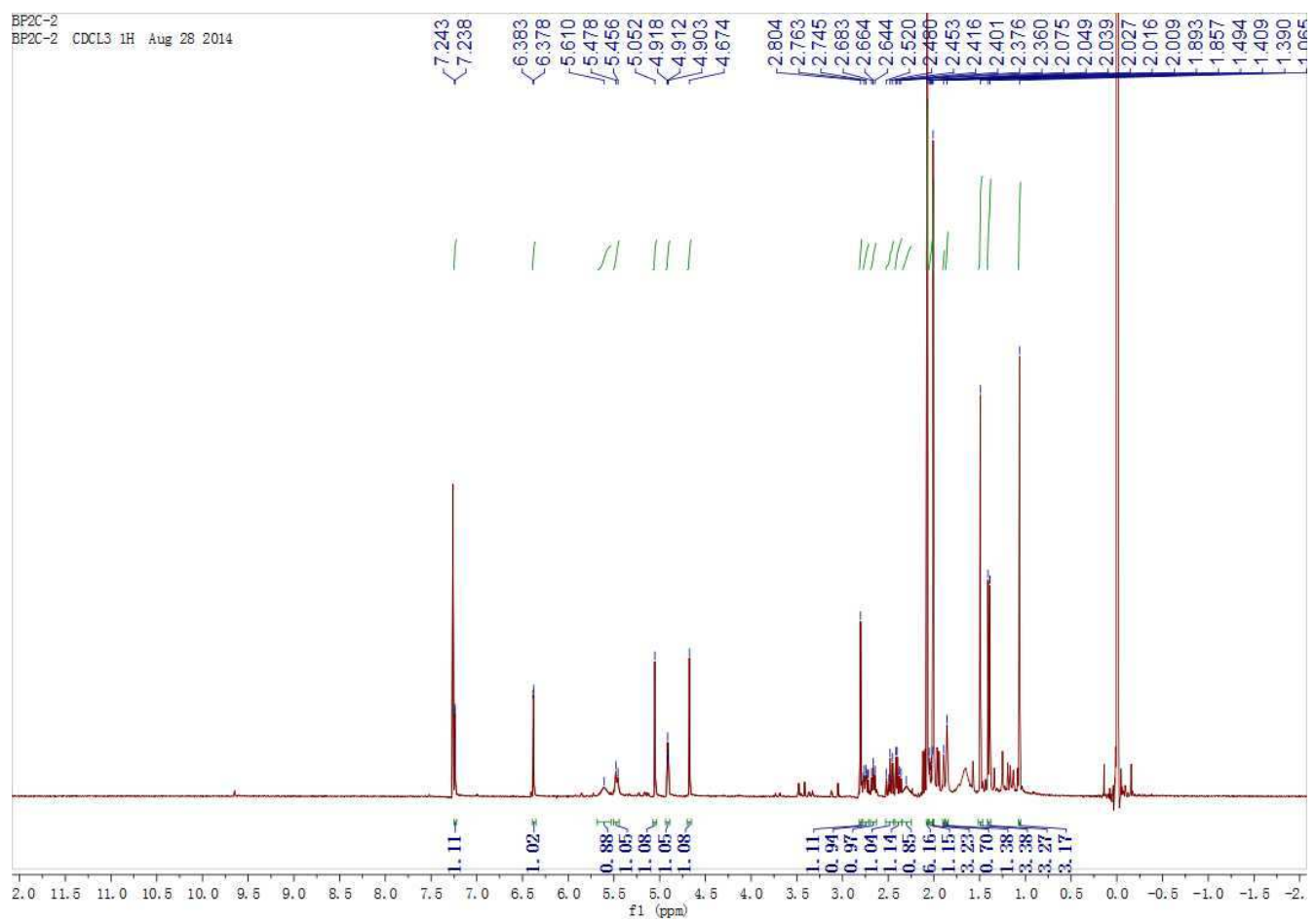

S1. The ${ }^{1} \mathrm{H}$ NMR (400 MHz, $\mathrm{CDCl}_{3}$ ) Spectrum of compound 1

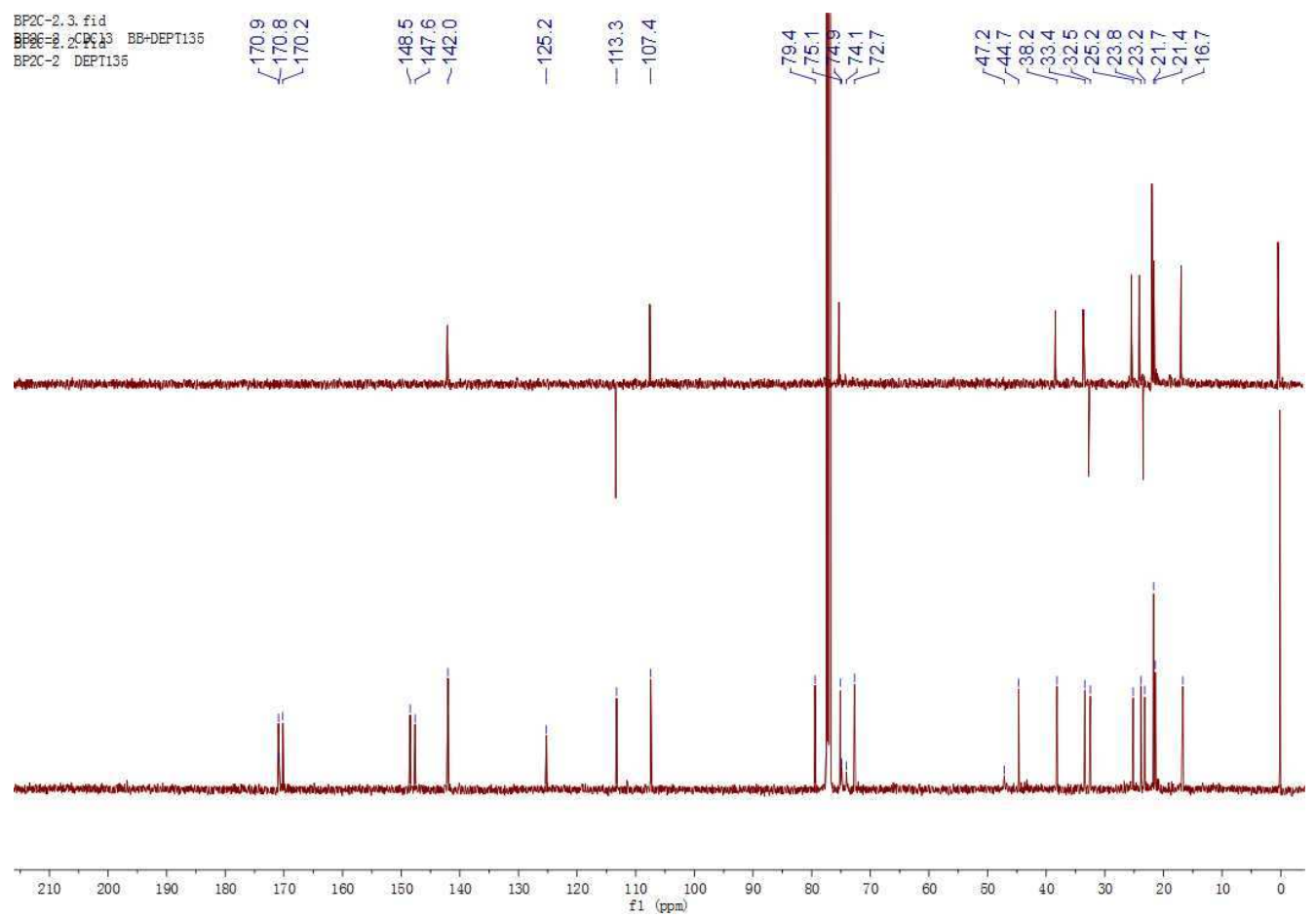

S2. The ${ }^{13} \mathrm{C}$ NMR $\left(100 \mathrm{MHz}, \mathrm{CDCl}_{3}\right)$ Spectrum of compound $\mathbf{1}$ 


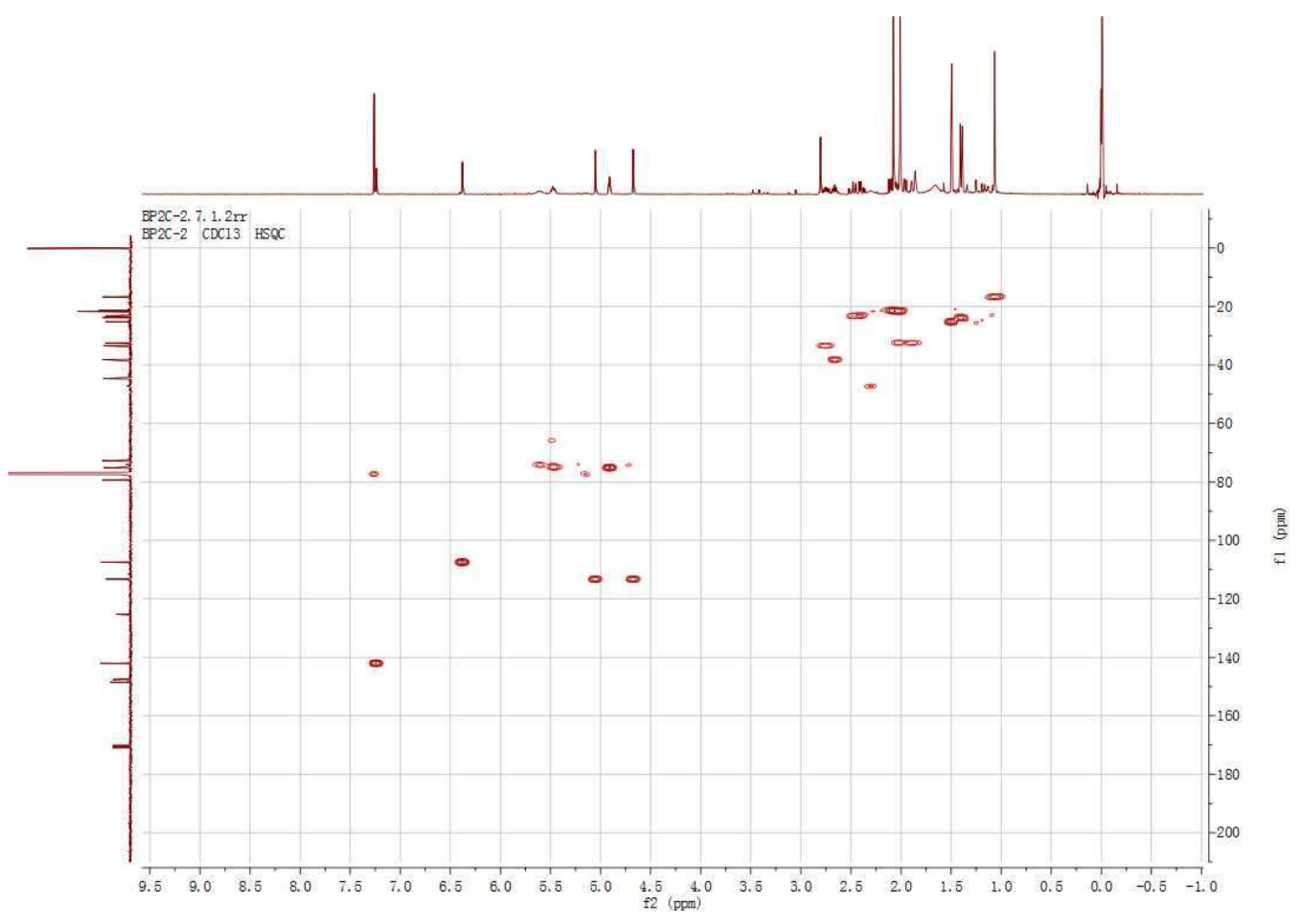

S3. The ${ }^{1} \mathrm{H}-{ }^{13} \mathrm{C}$ HMQC (400 MHz, $\mathrm{CDCl}_{3}$ ) Spectrum of compound 1

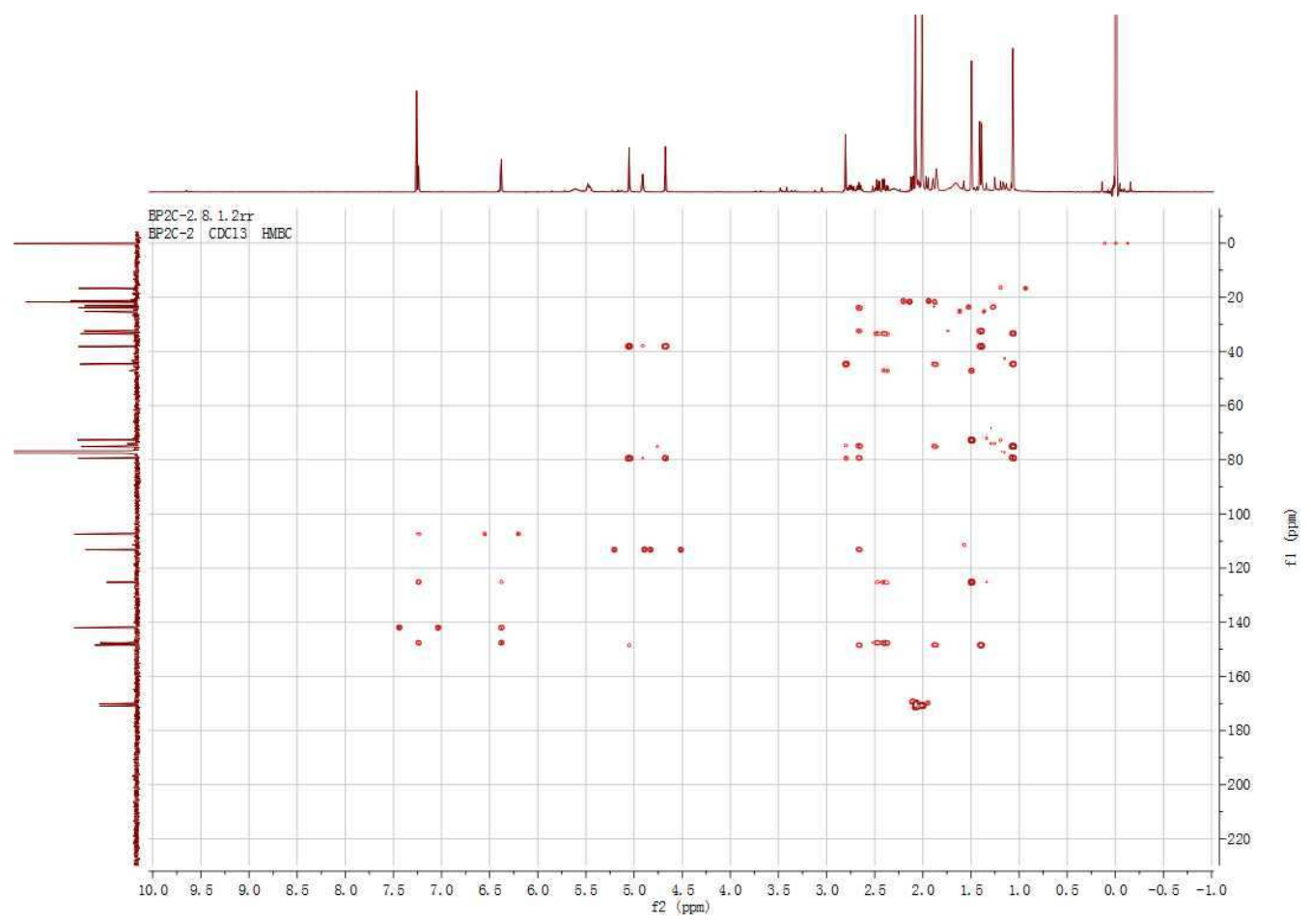

S4. The ${ }^{1} \mathrm{H}-{ }^{13} \mathrm{C} \mathrm{HMBC}\left(400 \mathrm{MHz}, \mathrm{CDCl}_{3}\right.$ ) Spectrum of compound 1 


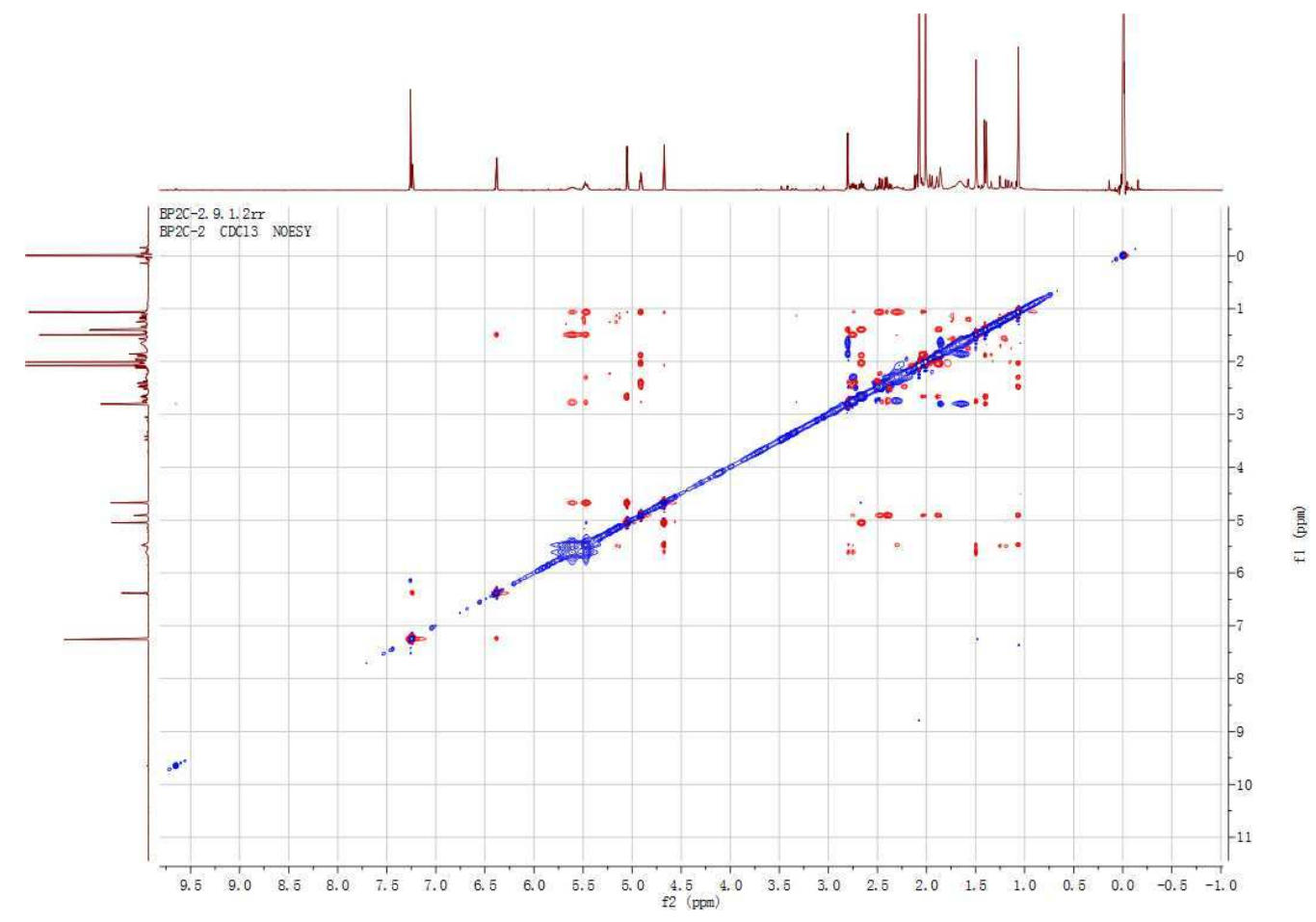

S5. The ${ }^{1} \mathrm{H}-{ }^{1} \mathrm{H}$ ROESY (400 MHz, $\mathrm{CDCl}_{3}$ ) Spectrum of compound $\mathbf{1}$

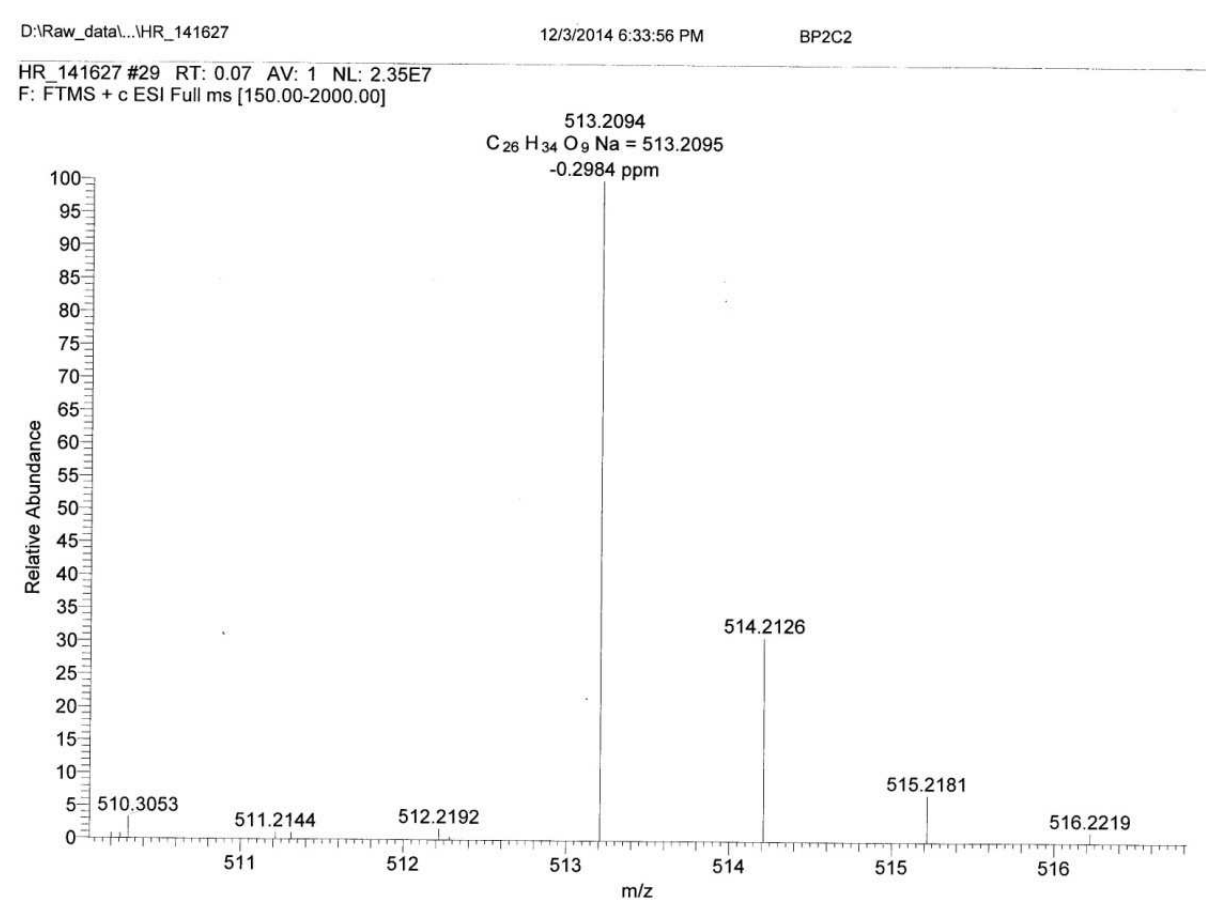

S6. The HR-ESI-MS spectrum of compound 1 


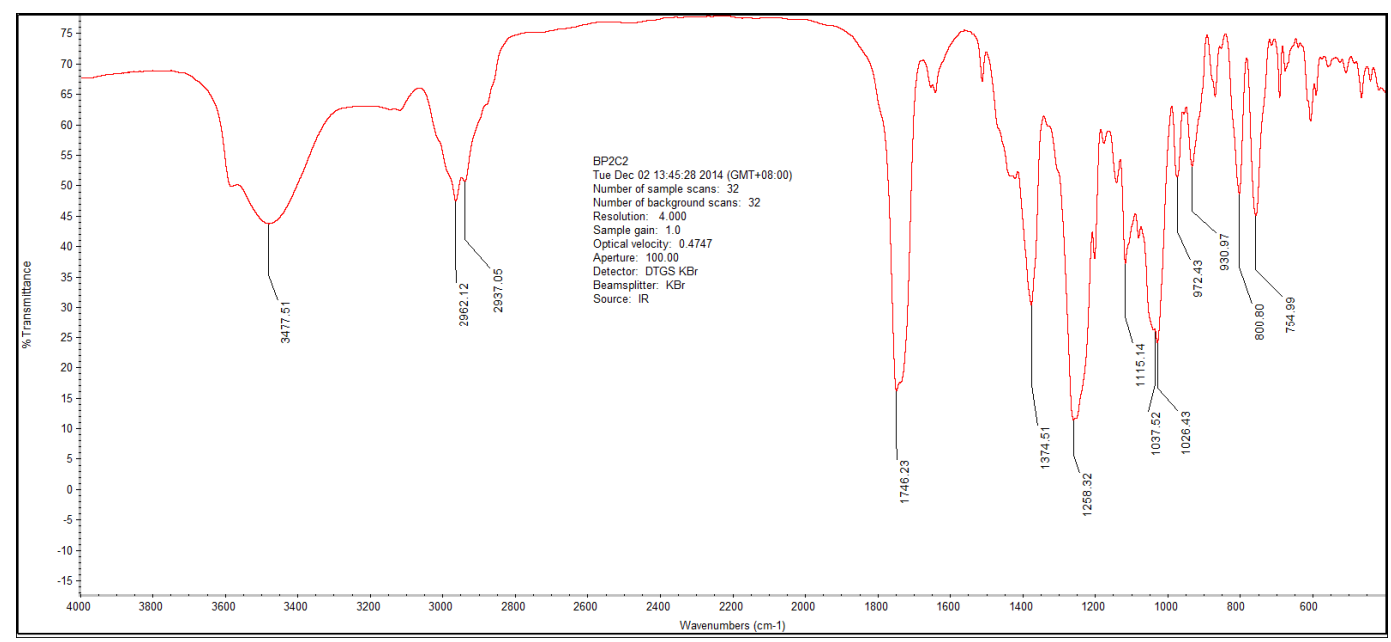

S7. The IR Spectrum of compound $\mathbf{1}$

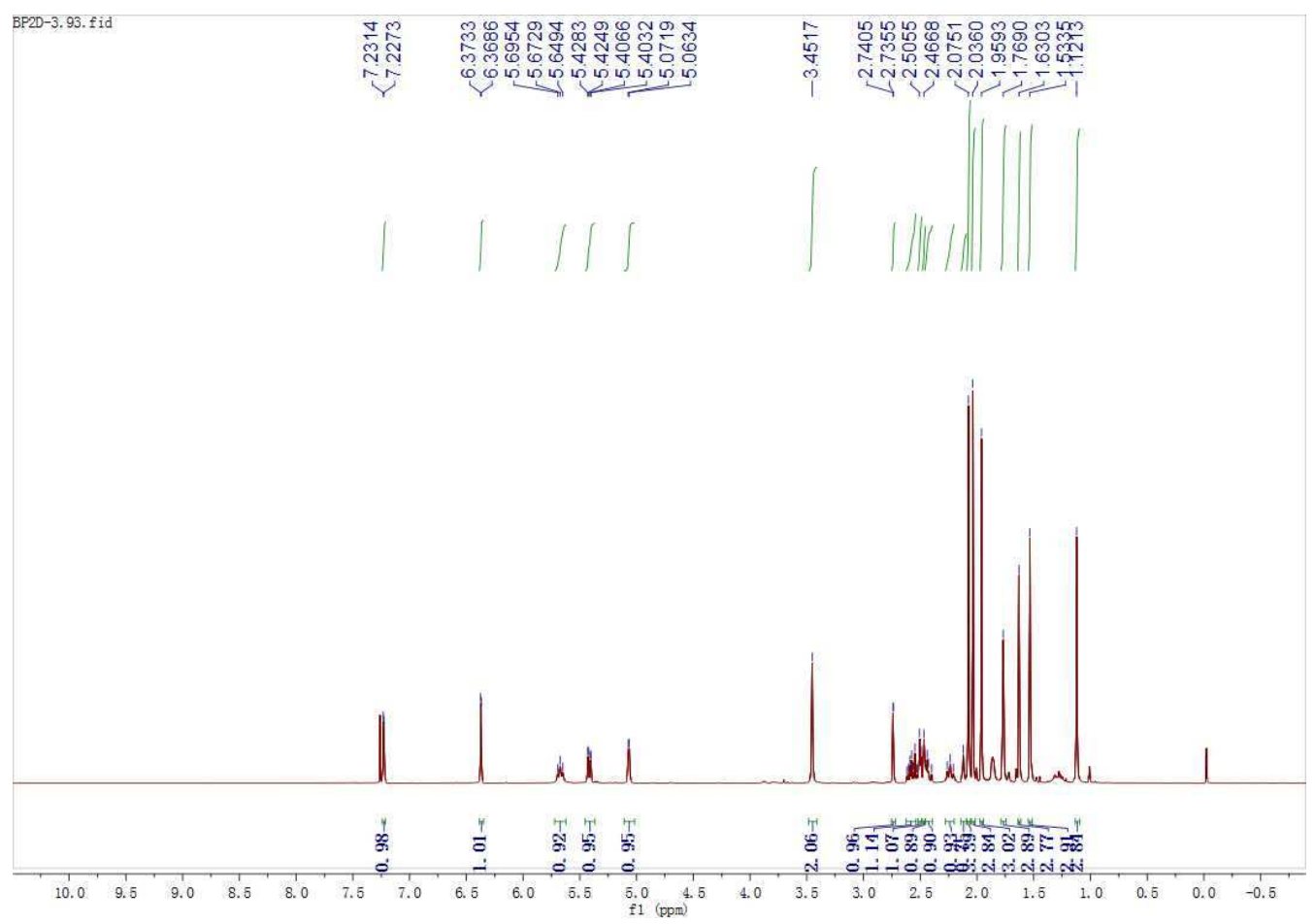

S8. The ${ }^{1} \mathrm{H}$ NMR (400 MHz, $\mathrm{CDCl}_{3}$ ) Spectrum of compound 2 

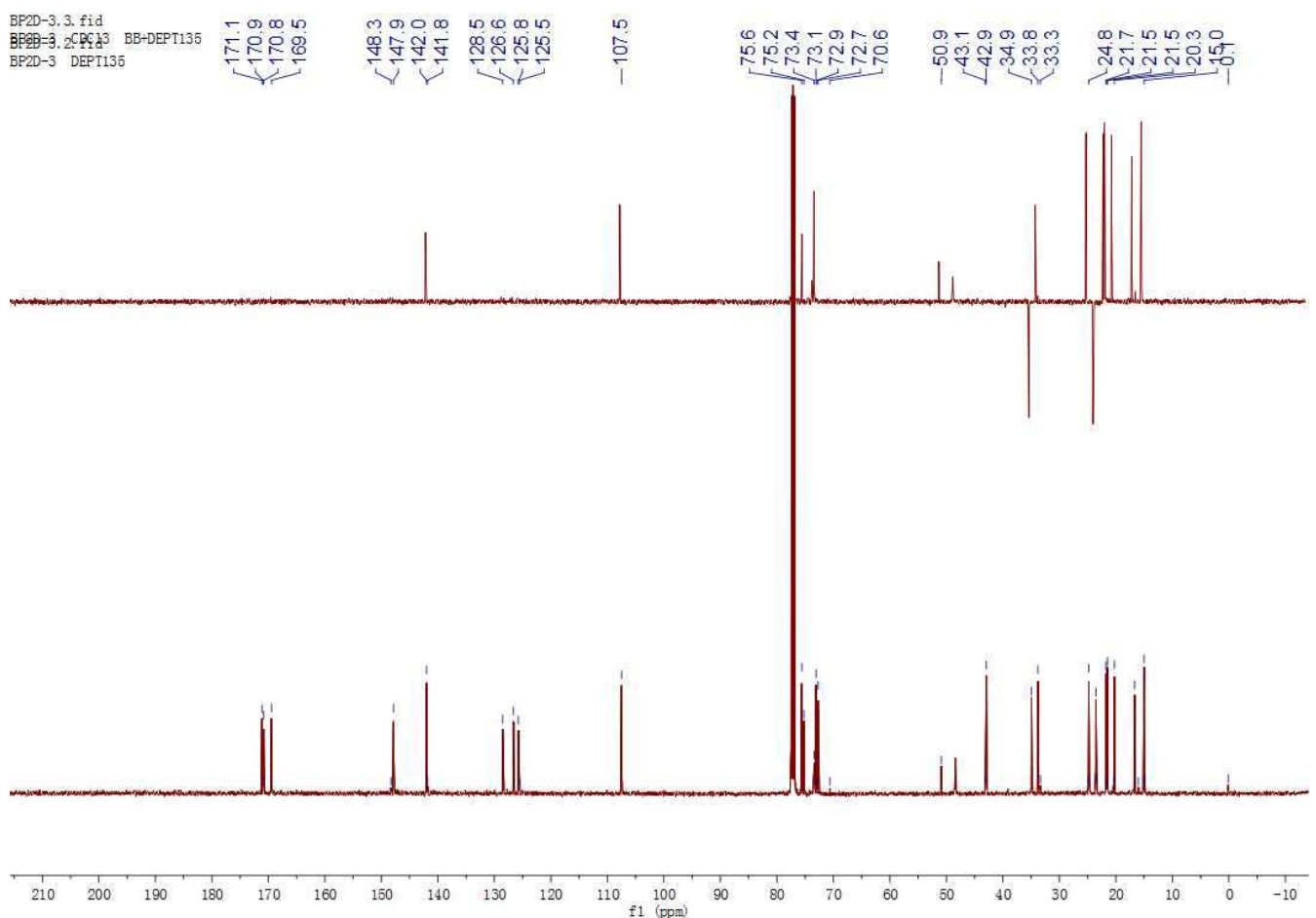

S9. The ${ }^{13} \mathrm{C}$ NMR (100 MHz, $\mathrm{CDCl}_{3}$ ) Spectrum of compound 2

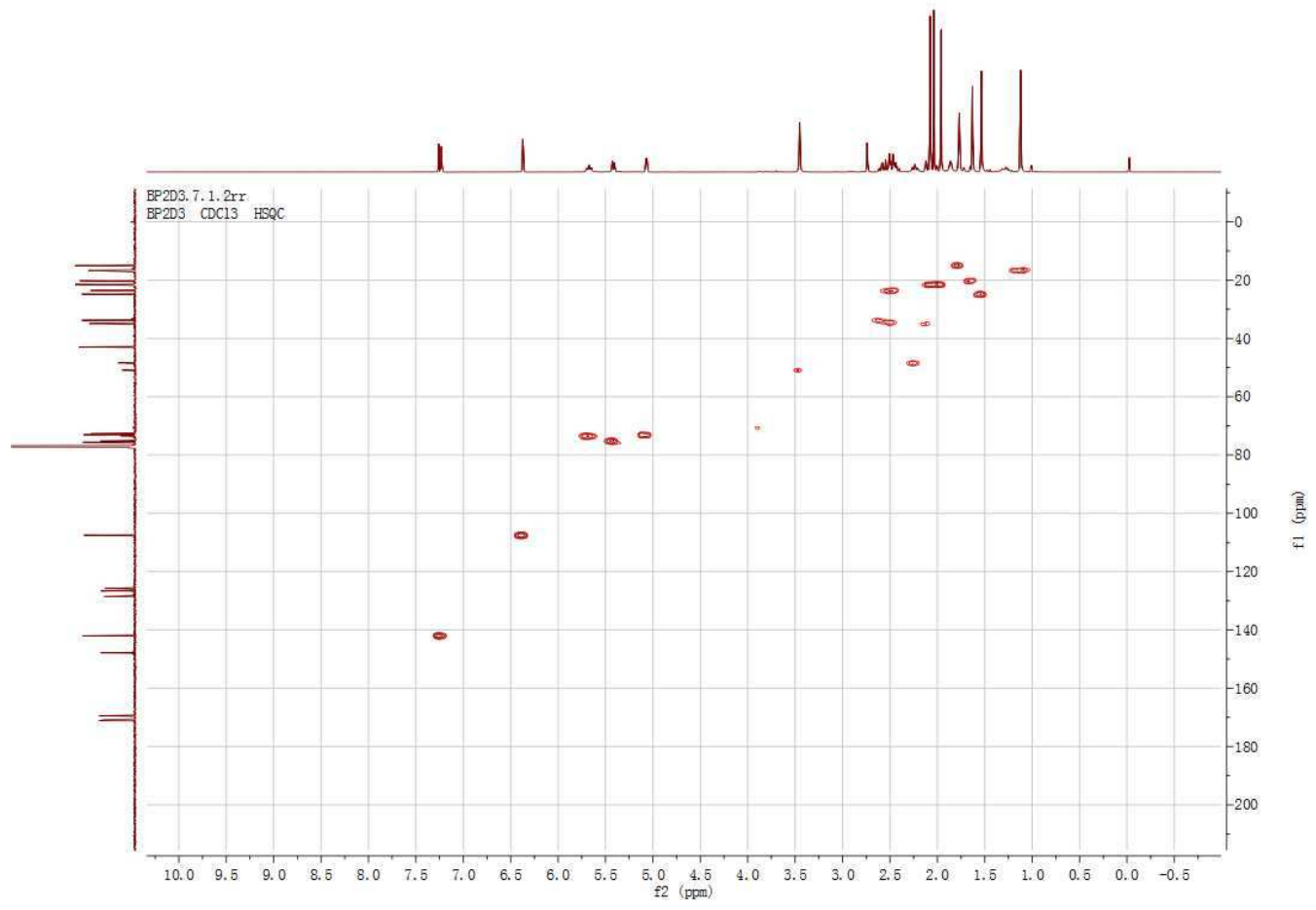

S10. The ${ }^{1} \mathrm{H}-{ }^{13} \mathrm{C}$ HMQC (400 MHz, $\mathrm{CDCl}_{3}$ ) Spectrum of compound 2 


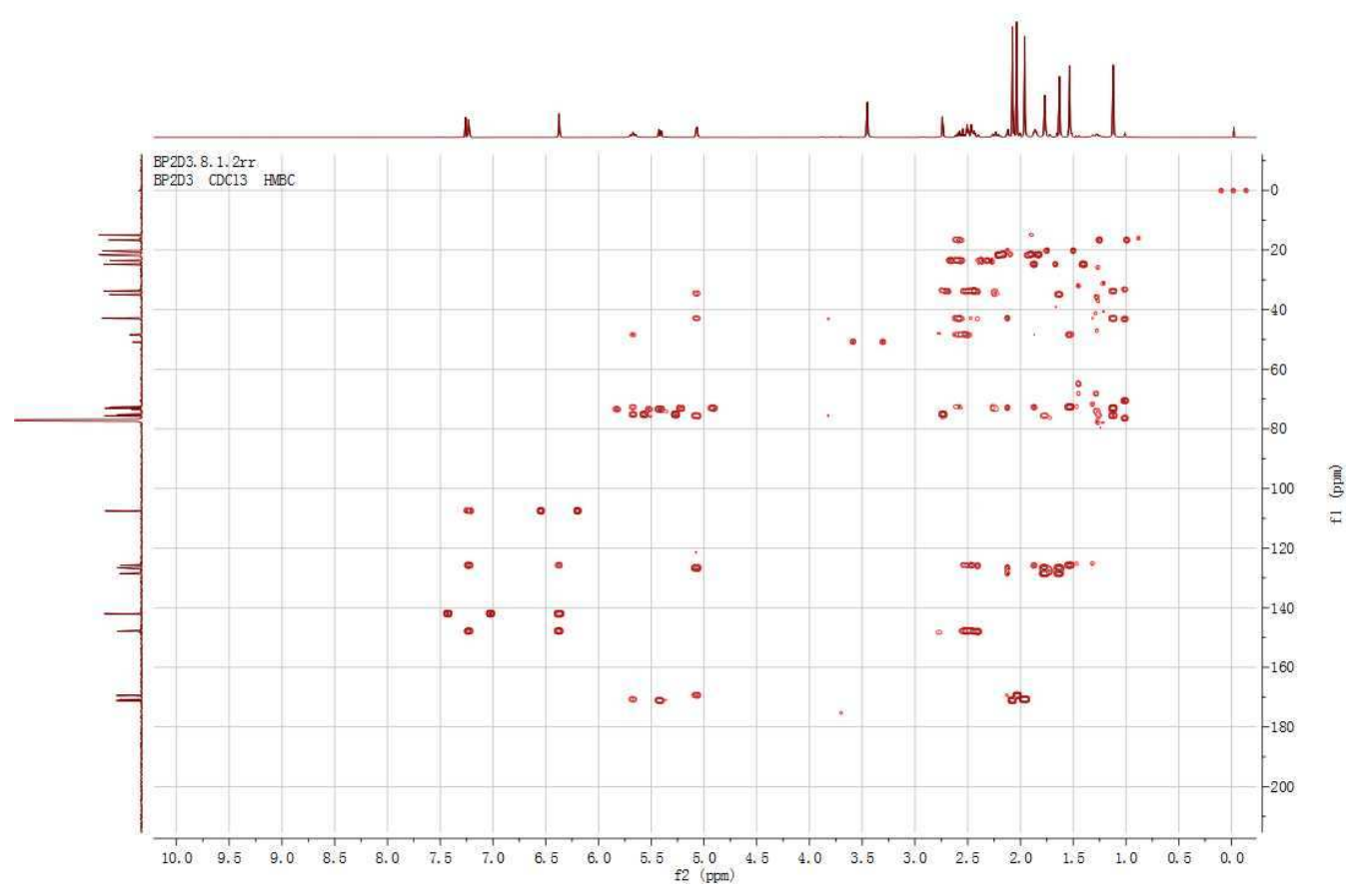

S11. The ${ }^{1} \mathrm{H}-{ }^{13} \mathrm{C}$ HMBC (400 MHz, $\mathrm{CDCl}_{3}$ ) Spectrum of compound 2

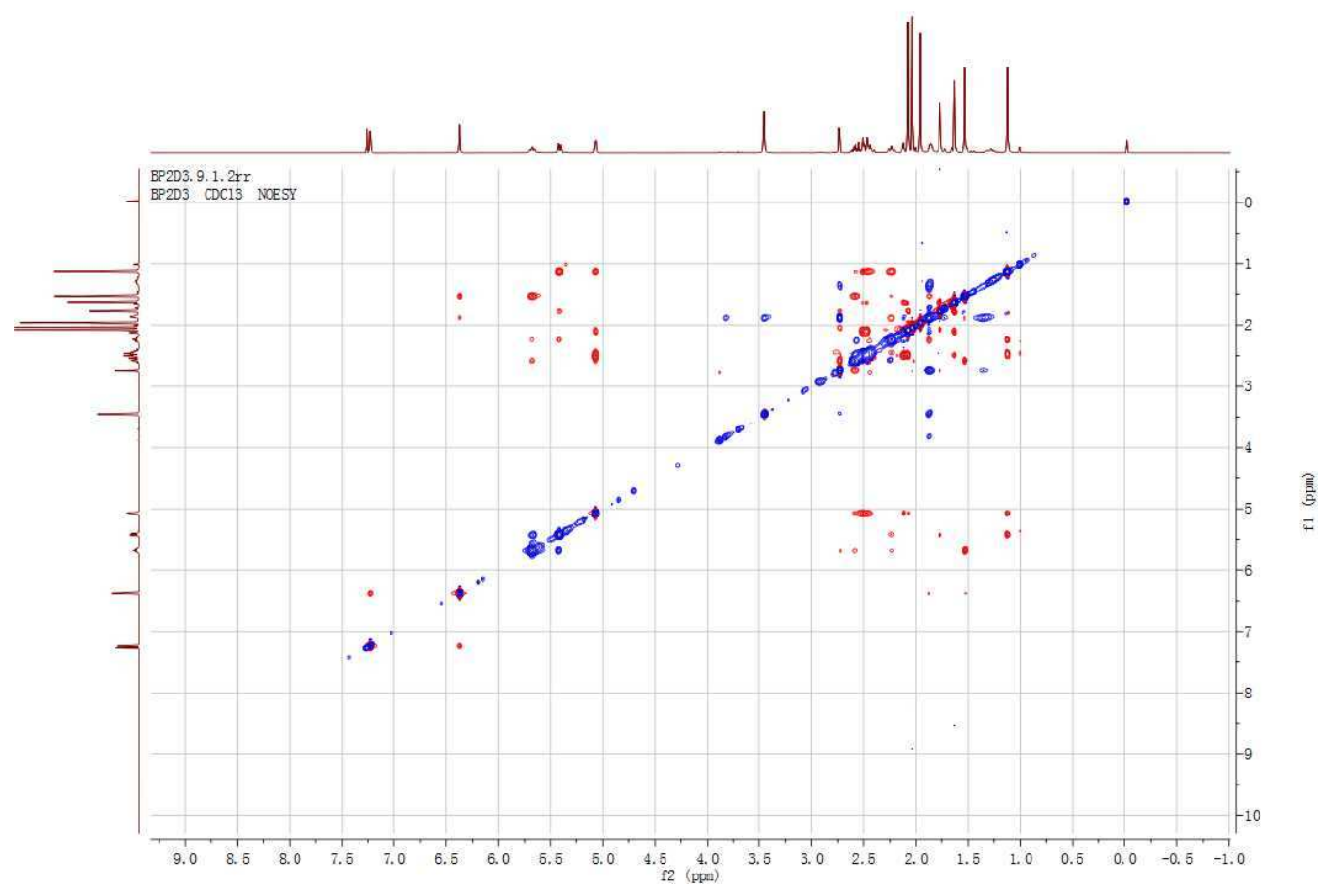

S12. The ${ }^{1} \mathrm{H}-{ }^{1} \mathrm{H}$ ROESY (400 MHz, $\mathrm{CDCl}_{3}$ ) Spectrum of compound 2 


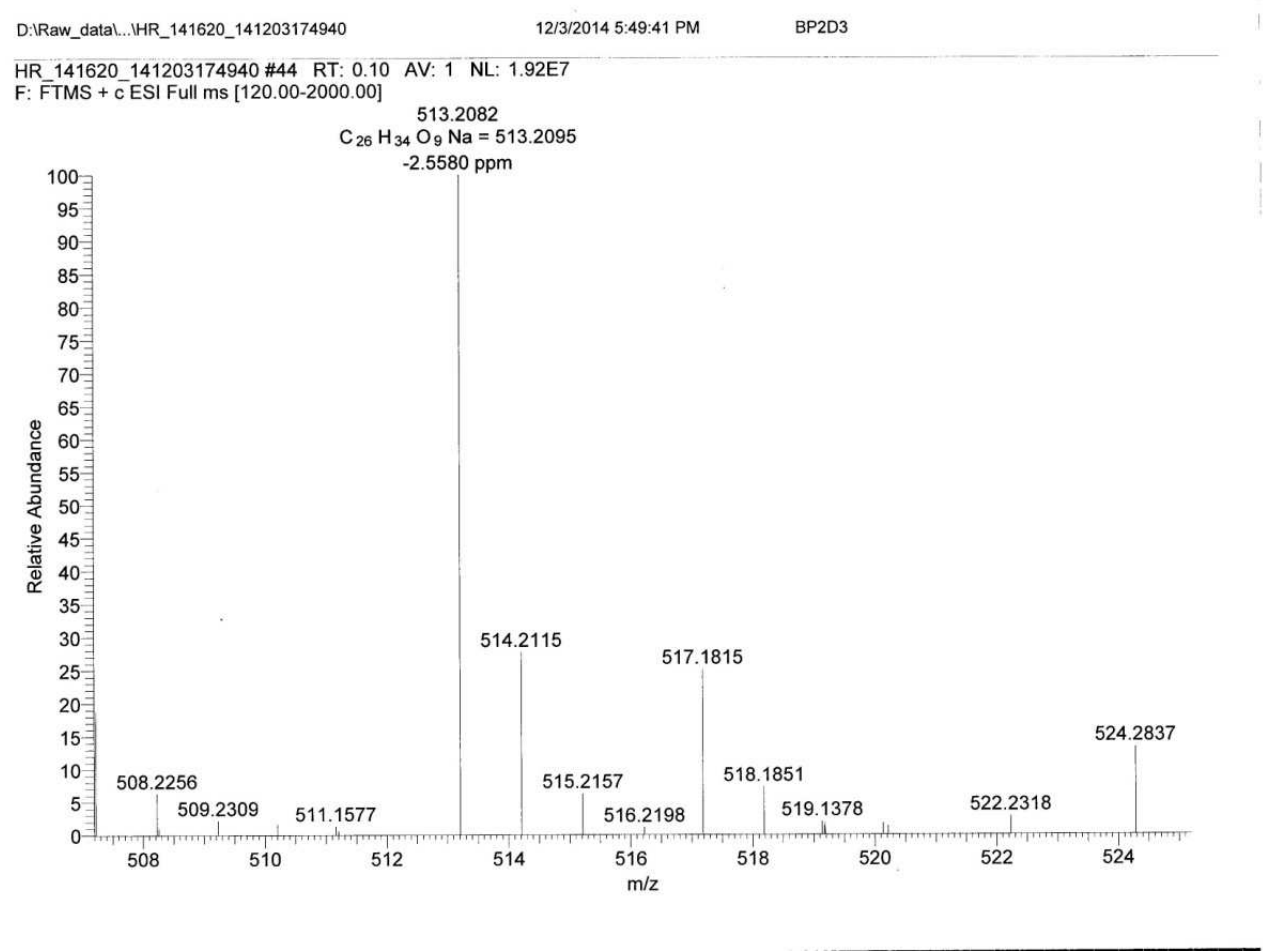

S13. The HR-ESI-MS spectrum of compound 2

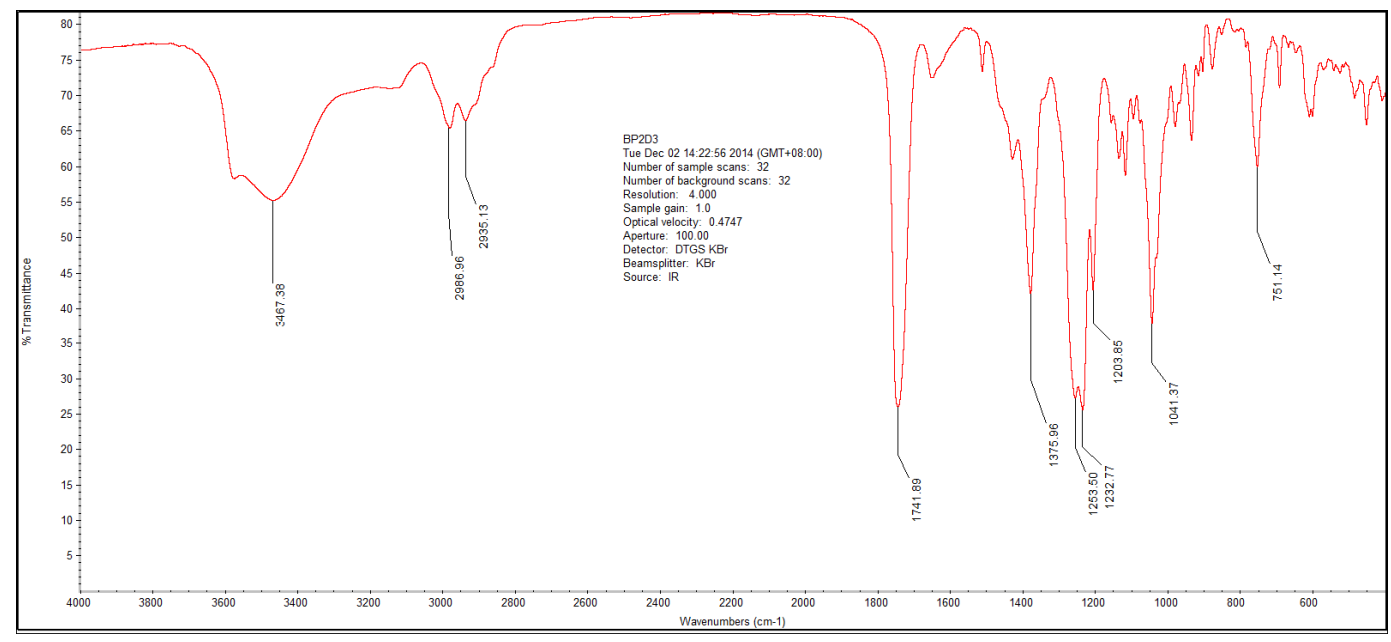

S14. The IR Spectrum of compound 2 


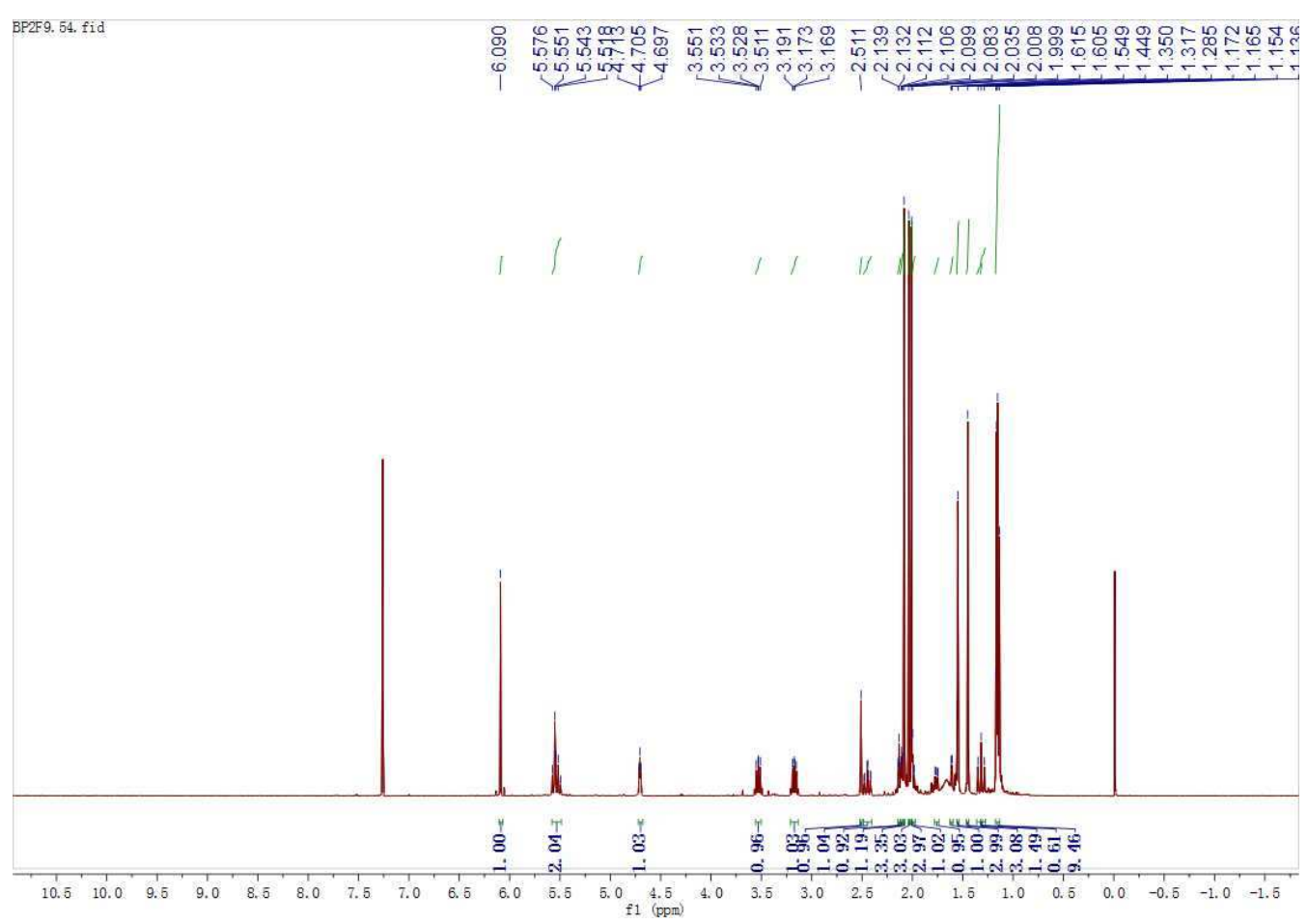

S15. The ${ }^{1} \mathrm{H}$ NMR (400 MHz, $\mathrm{CDCl}_{3}$ ) Spectrum of compound 3

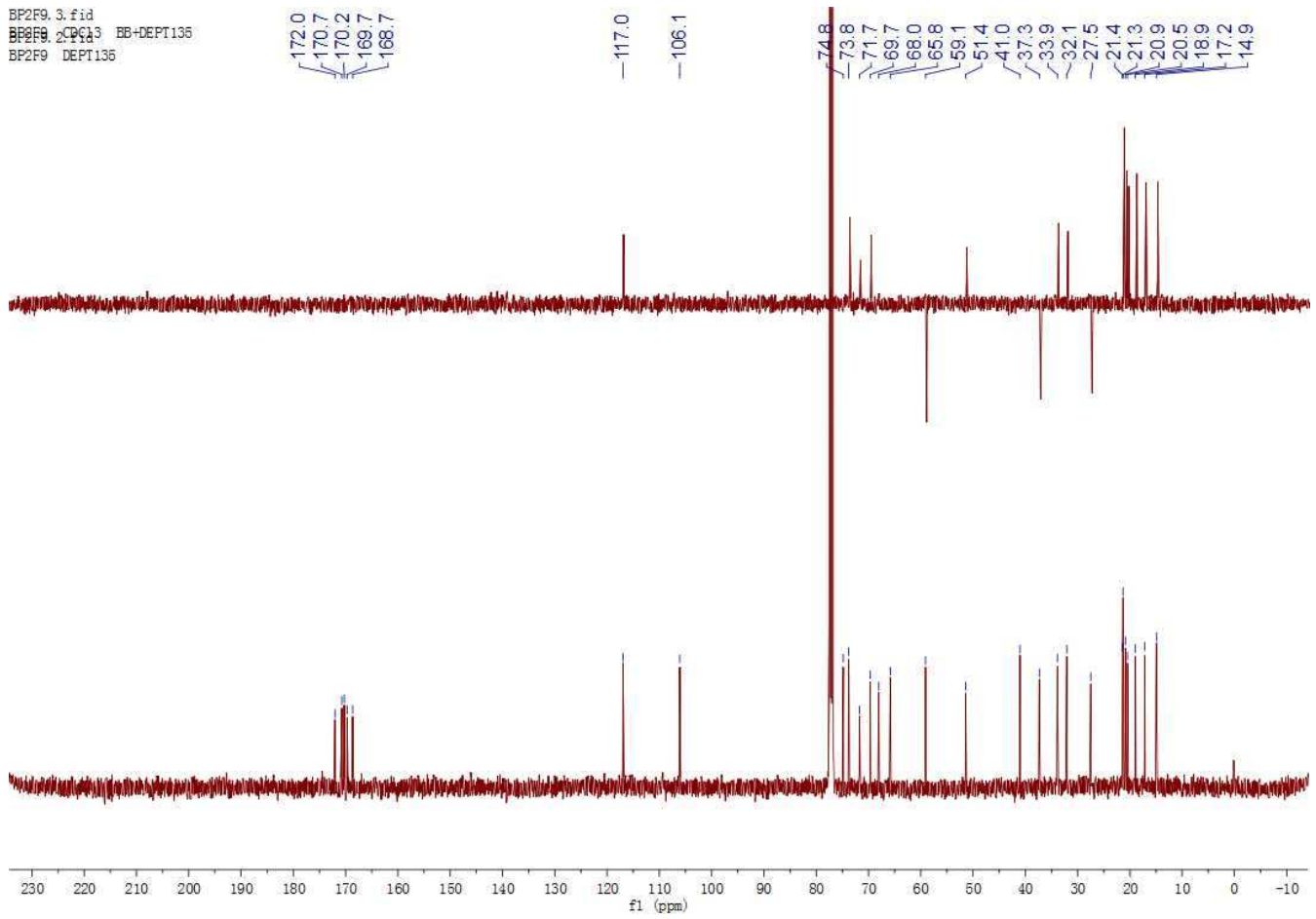

S16. The ${ }^{13} \mathrm{C}$ NMR (100 MHz, $\mathrm{CDCl}_{3}$ ) Spectrum of compound 3 


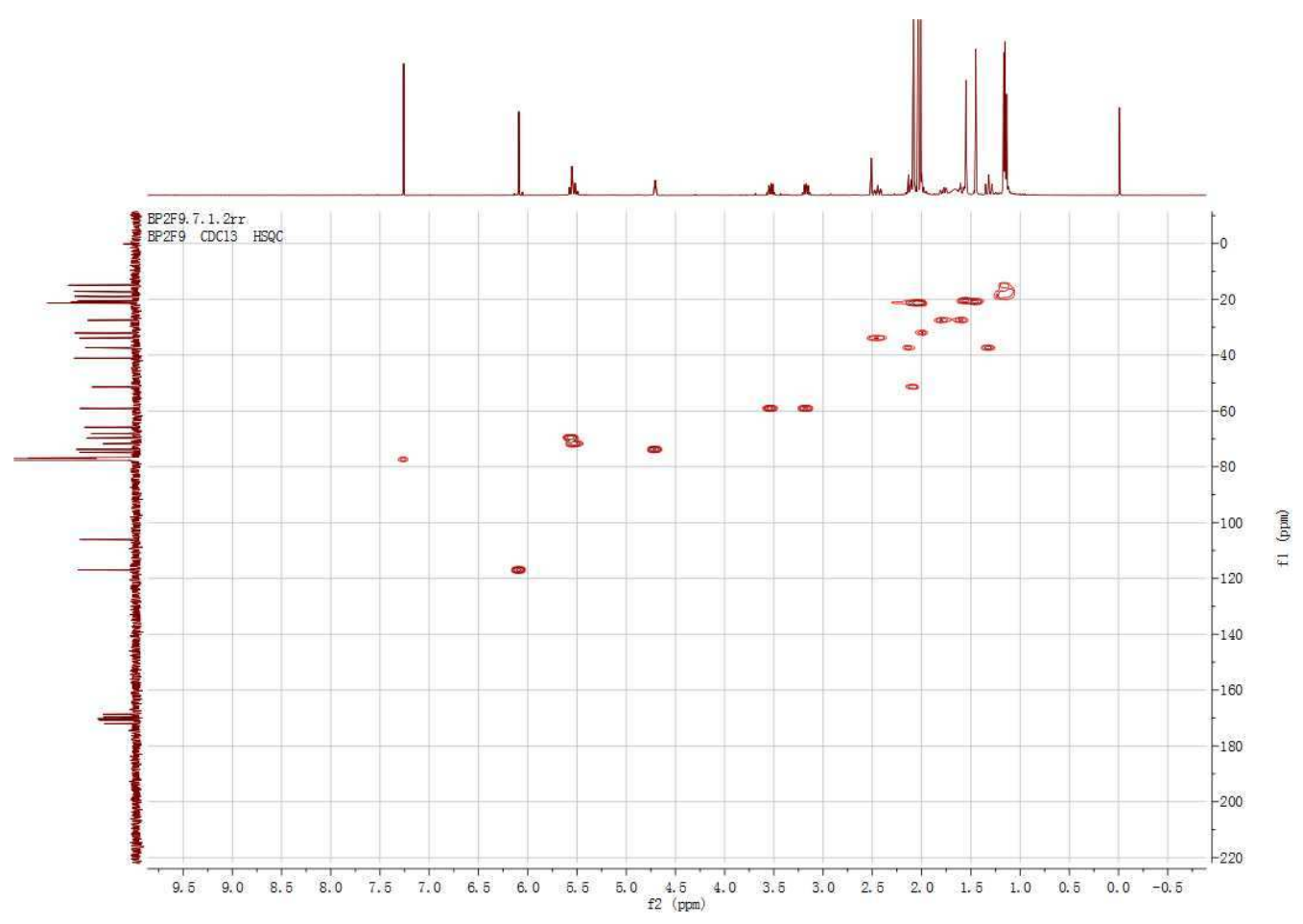

S17. The ${ }^{1} \mathrm{H}-{ }^{13} \mathrm{C}$ HMQC (400 MHz, $\mathrm{CDCl}_{3}$ ) Spectrum of compound 3

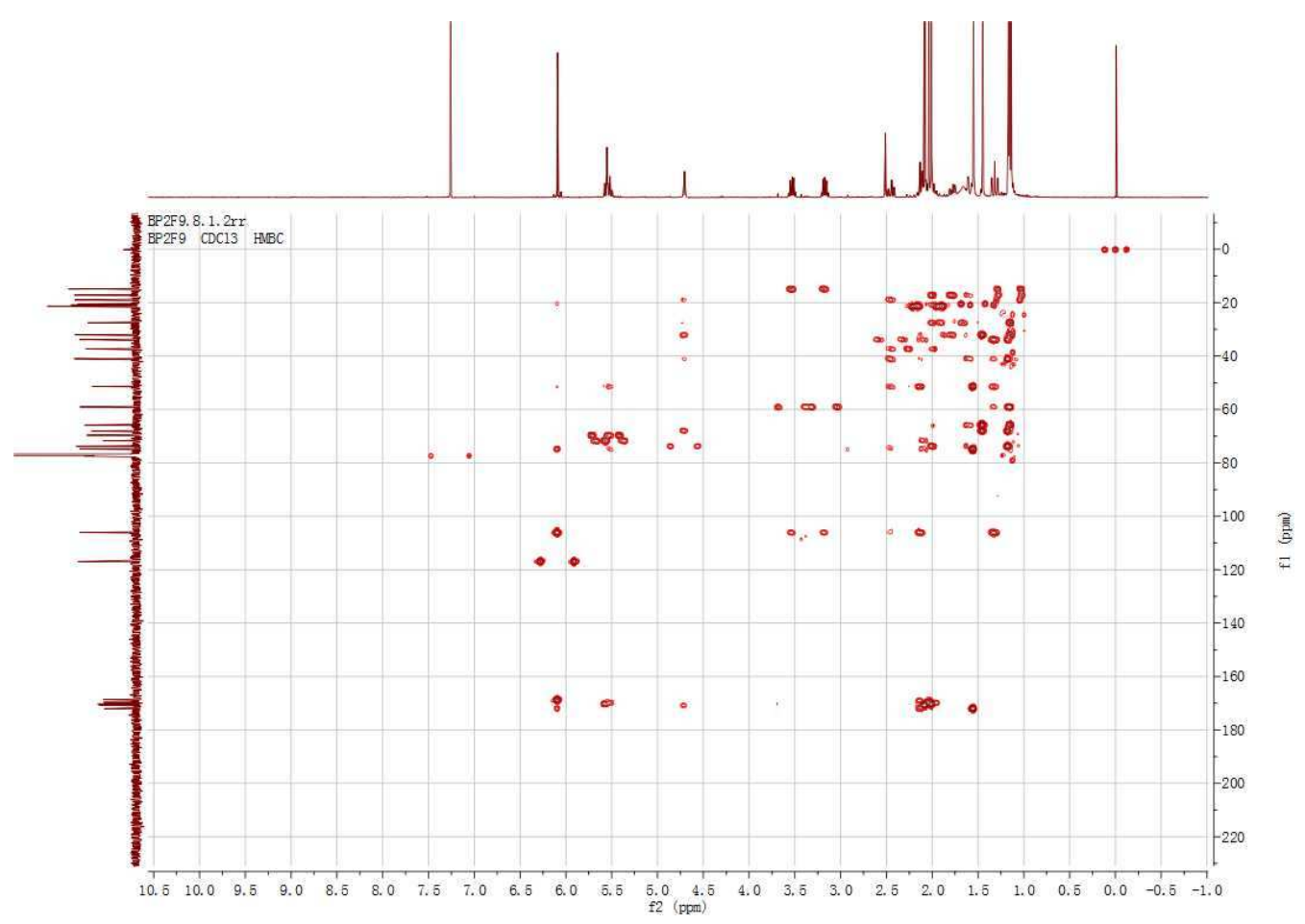

S18. The ${ }^{1} \mathrm{H}-{ }^{13} \mathrm{C}$ HMBC (400 MHz, $\mathrm{CDCl}_{3}$ ) Spectrum of compound 3 


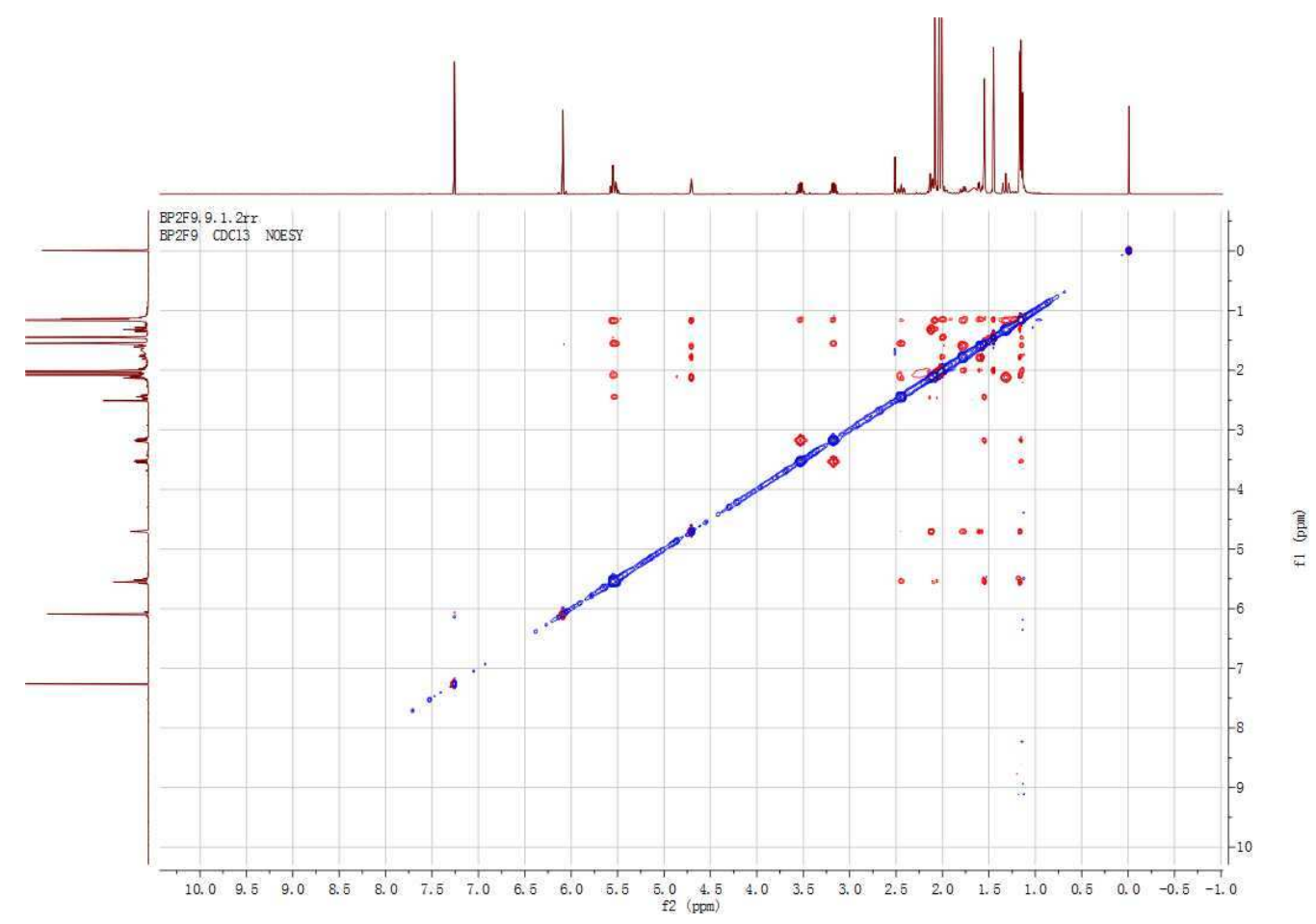

S19. The ${ }^{1} \mathrm{H}-{ }^{1} \mathrm{H}$ ROESY (400 MHz, $\mathrm{CDCl}_{3}$ ) Spectrum of compound 3

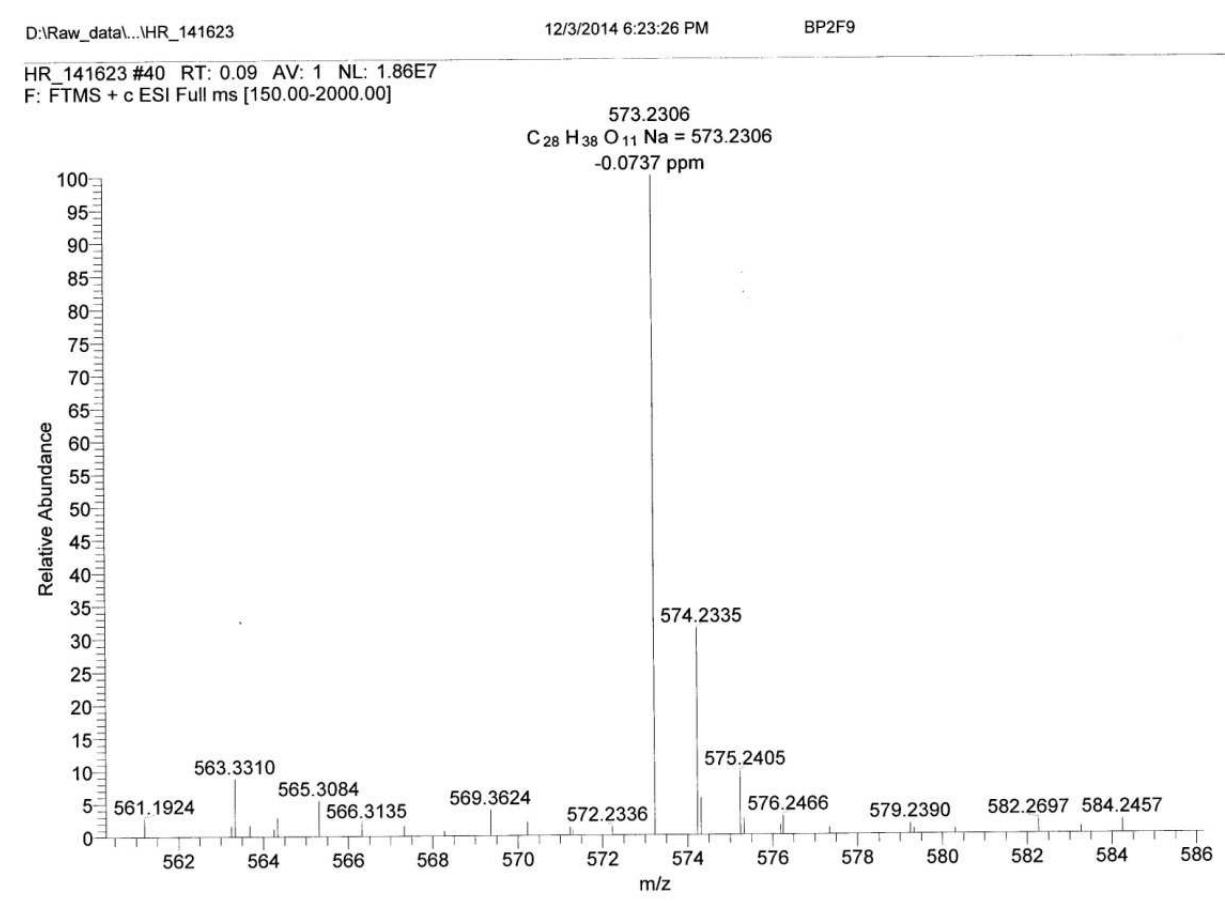

S20. The HR-ESI-MS spectrum of compound $\mathbf{3}$ 


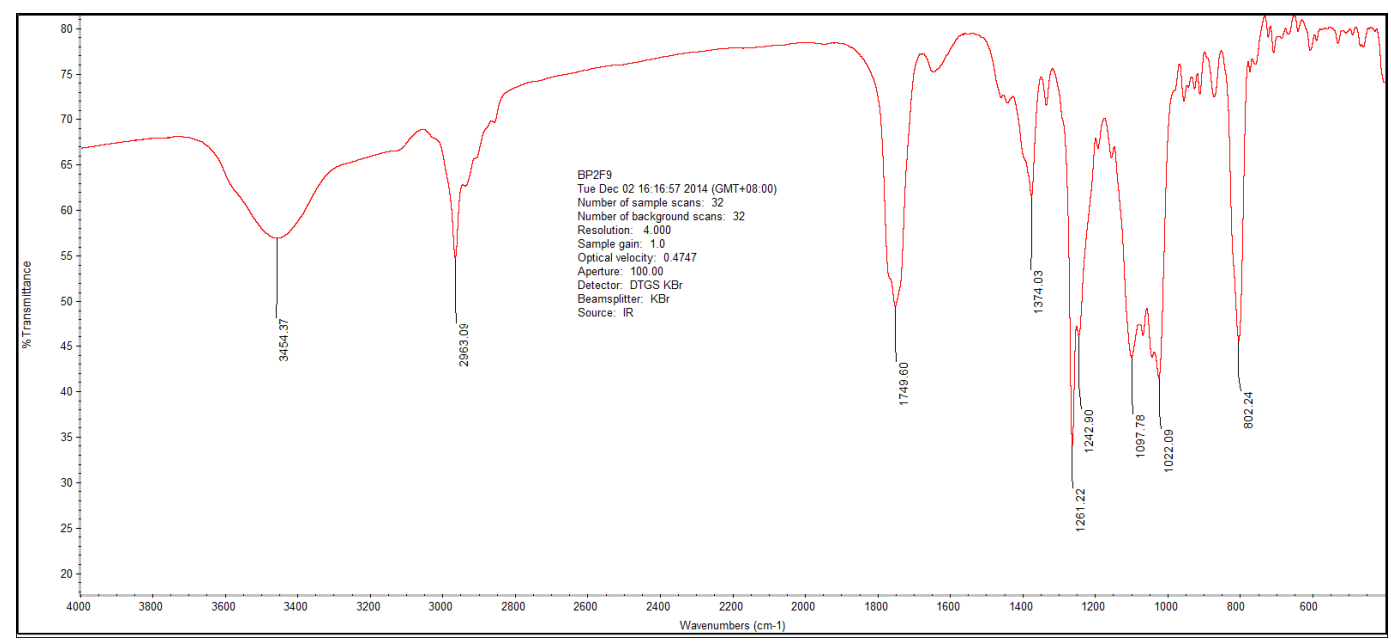

S21. The IR Spectrum of compound 3

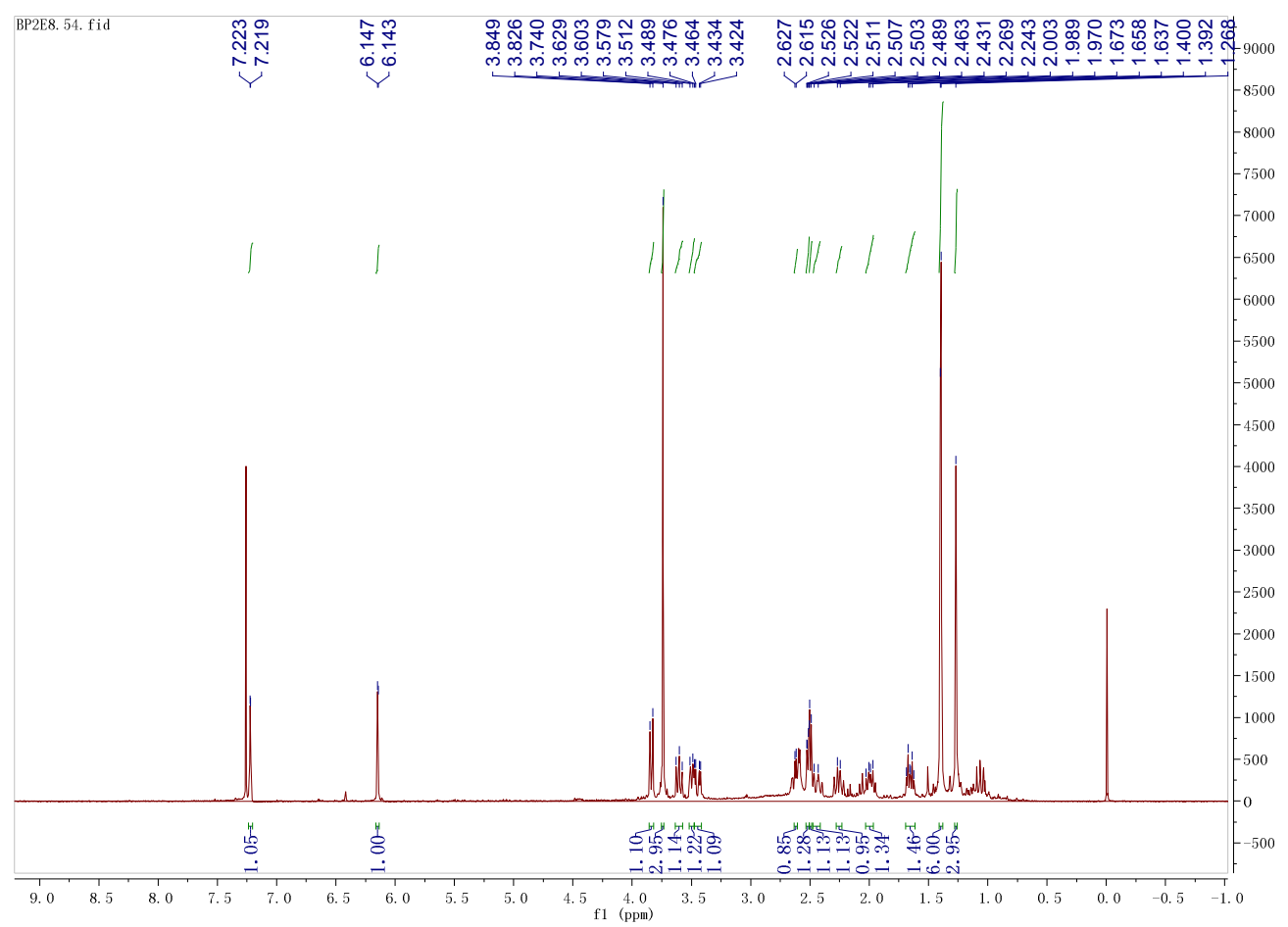

S22. The ${ }^{1} \mathrm{H}$ NMR (400 MHz, $\mathrm{CDCl}_{3}$ ) Spectrum of compound 4 


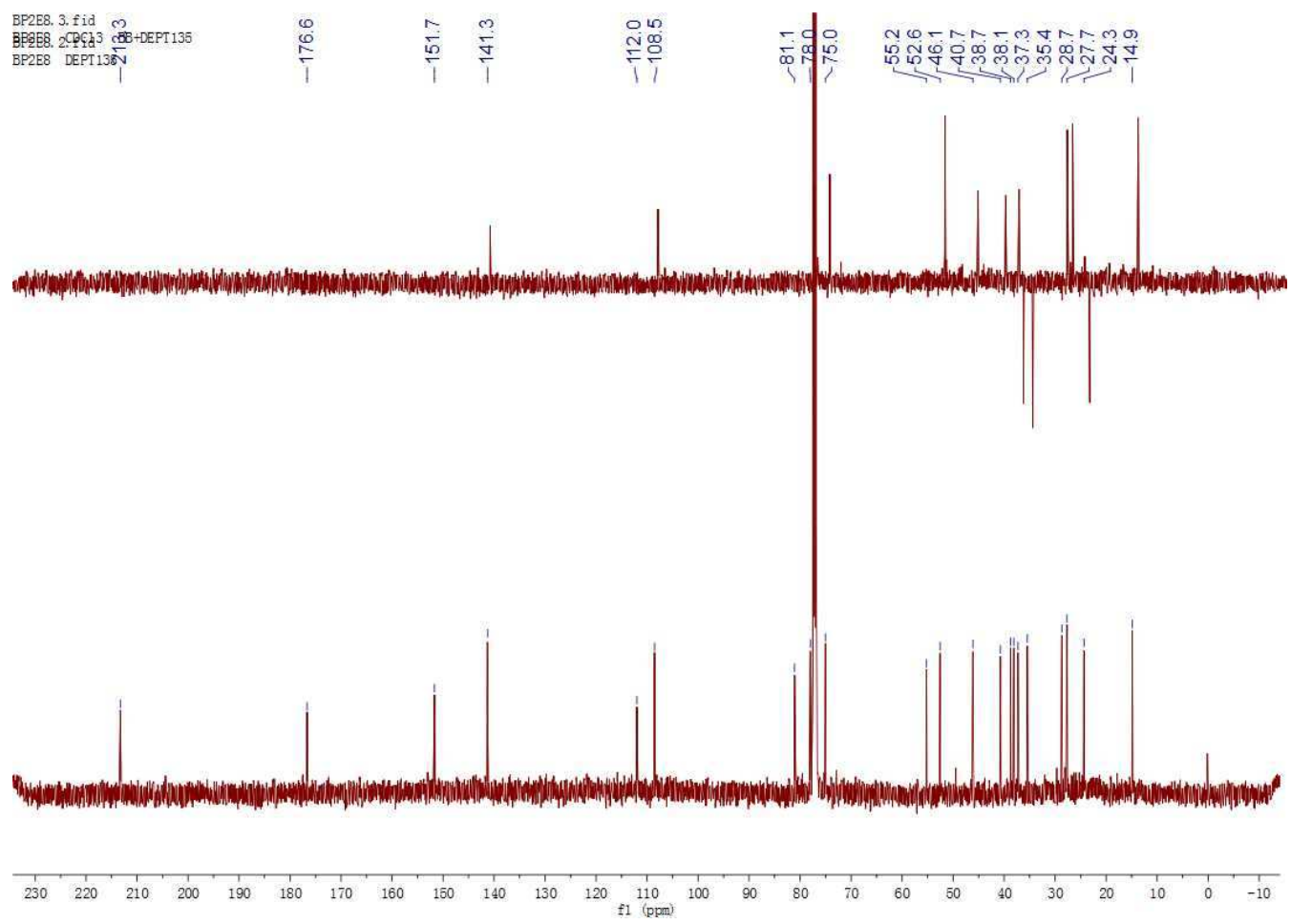

S23. The ${ }^{13} \mathrm{C}$ NMR (100 MHz, $\mathrm{CDCl}_{3}$ ) Spectrum of compound 4

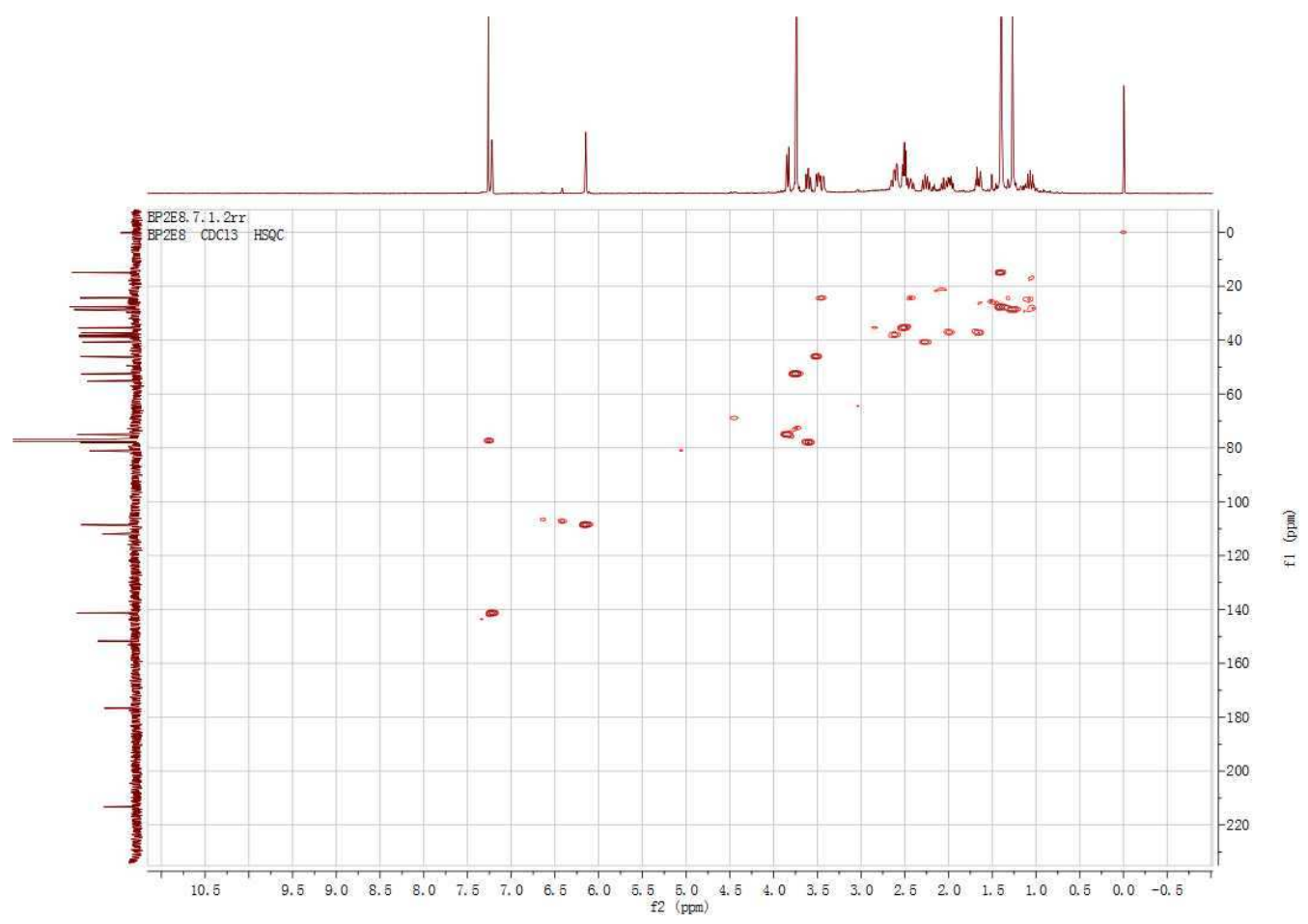

S24. The ${ }^{1} \mathrm{H}-{ }^{13} \mathrm{C}$ HMQC (400 MHz, $\mathrm{CDCl}_{3}$ ) Spectrum of compound 4 


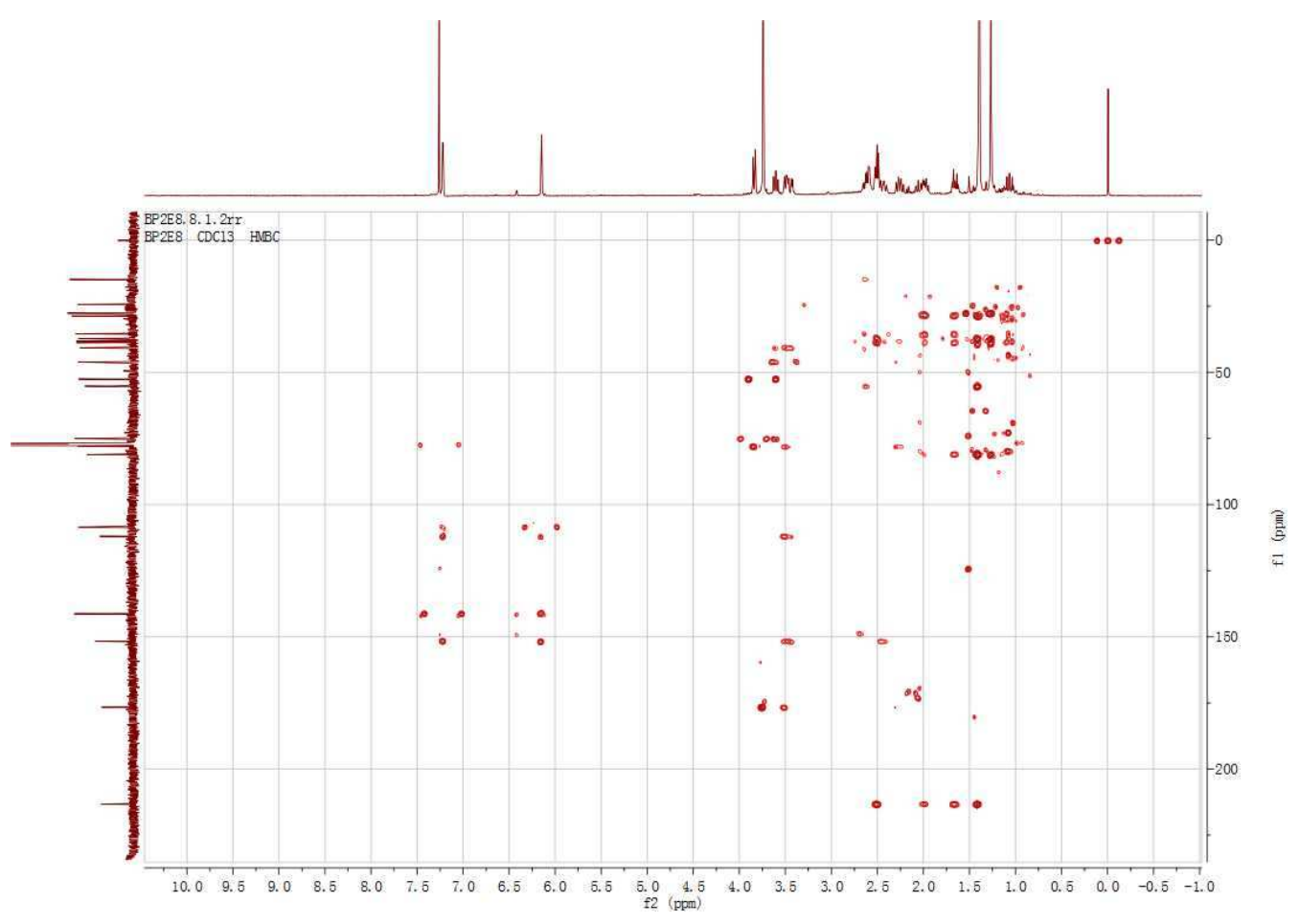

S25. The ${ }^{1} \mathrm{H}-{ }^{13} \mathrm{C}$ HMBC (400 MHz, $\mathrm{CDCl}_{3}$ ) Spectrum of compound 4

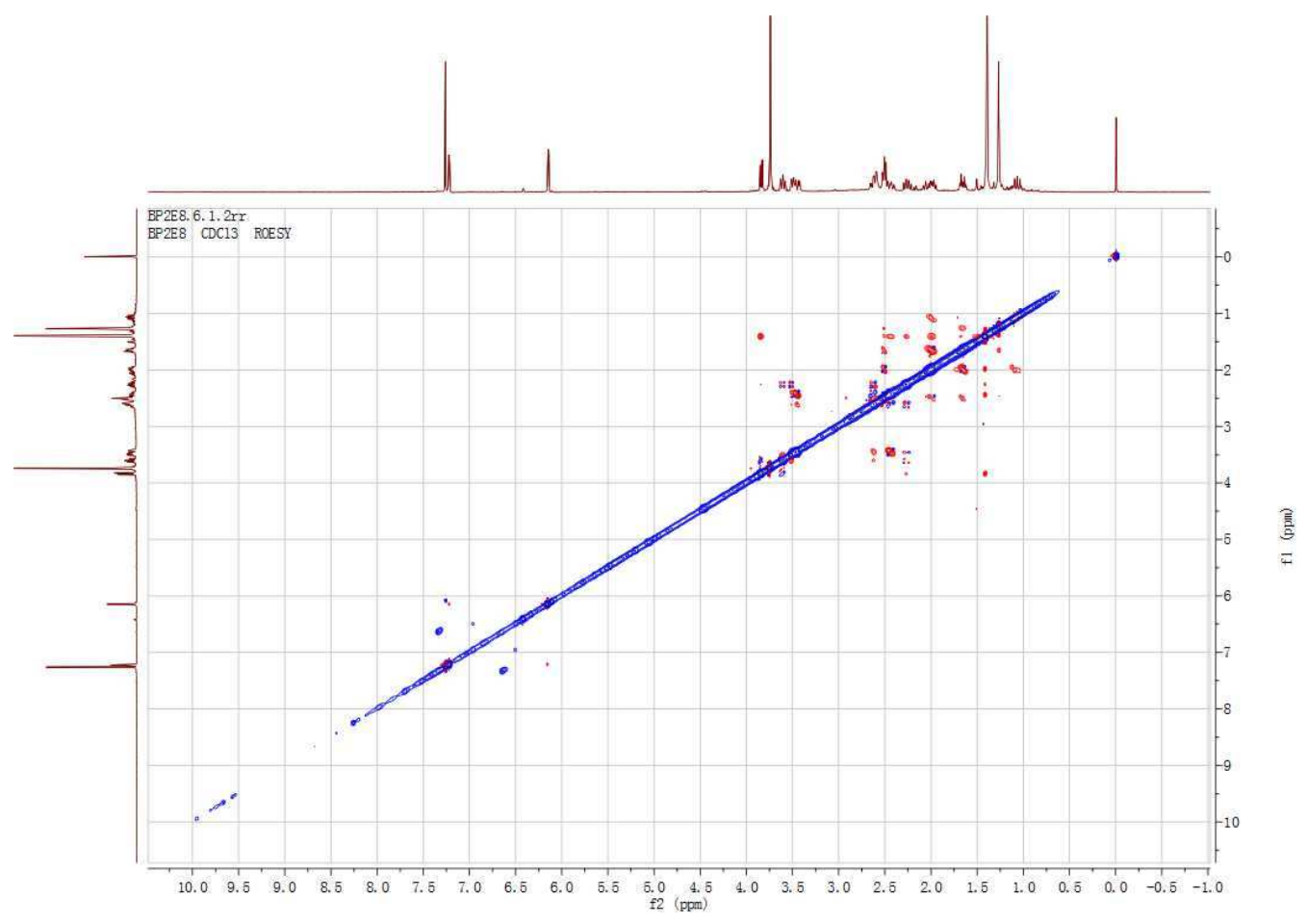

S26. The ${ }^{1} \mathrm{H}-{ }^{1} \mathrm{H}$ ROESY (400 MHz, $\mathrm{CDCl}_{3}$ ) Spectrum of compound 4 


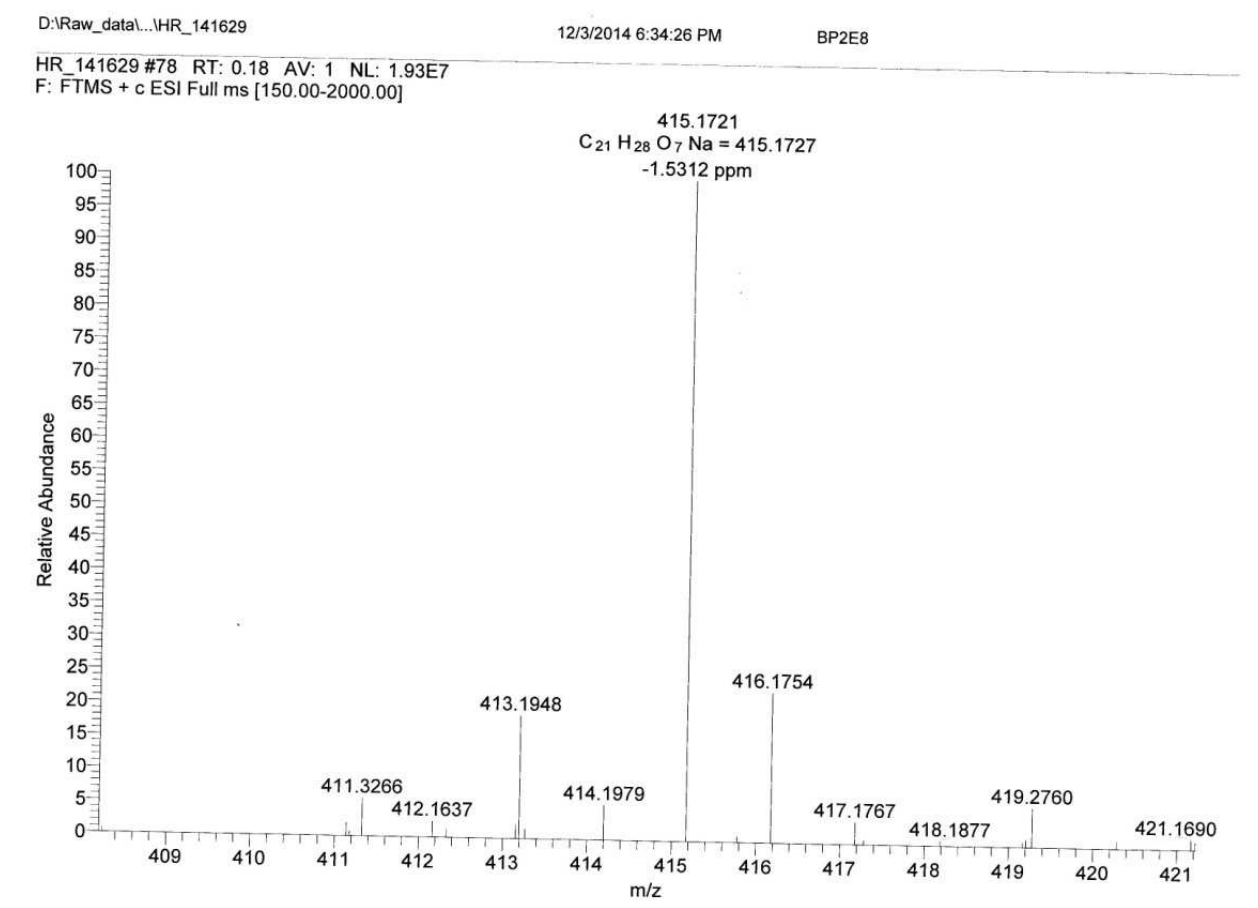

S27. The HR-ESI-MS spectrum of compound 4

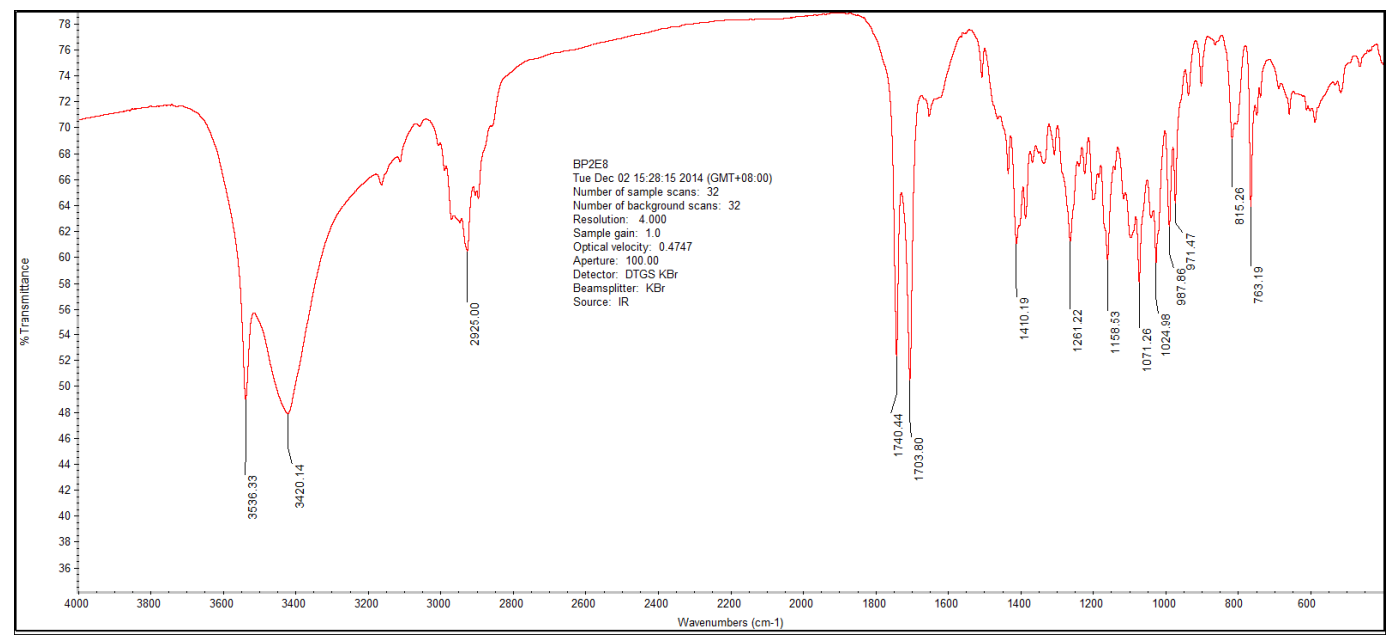

S28. The IR Spectrum of compound 4 


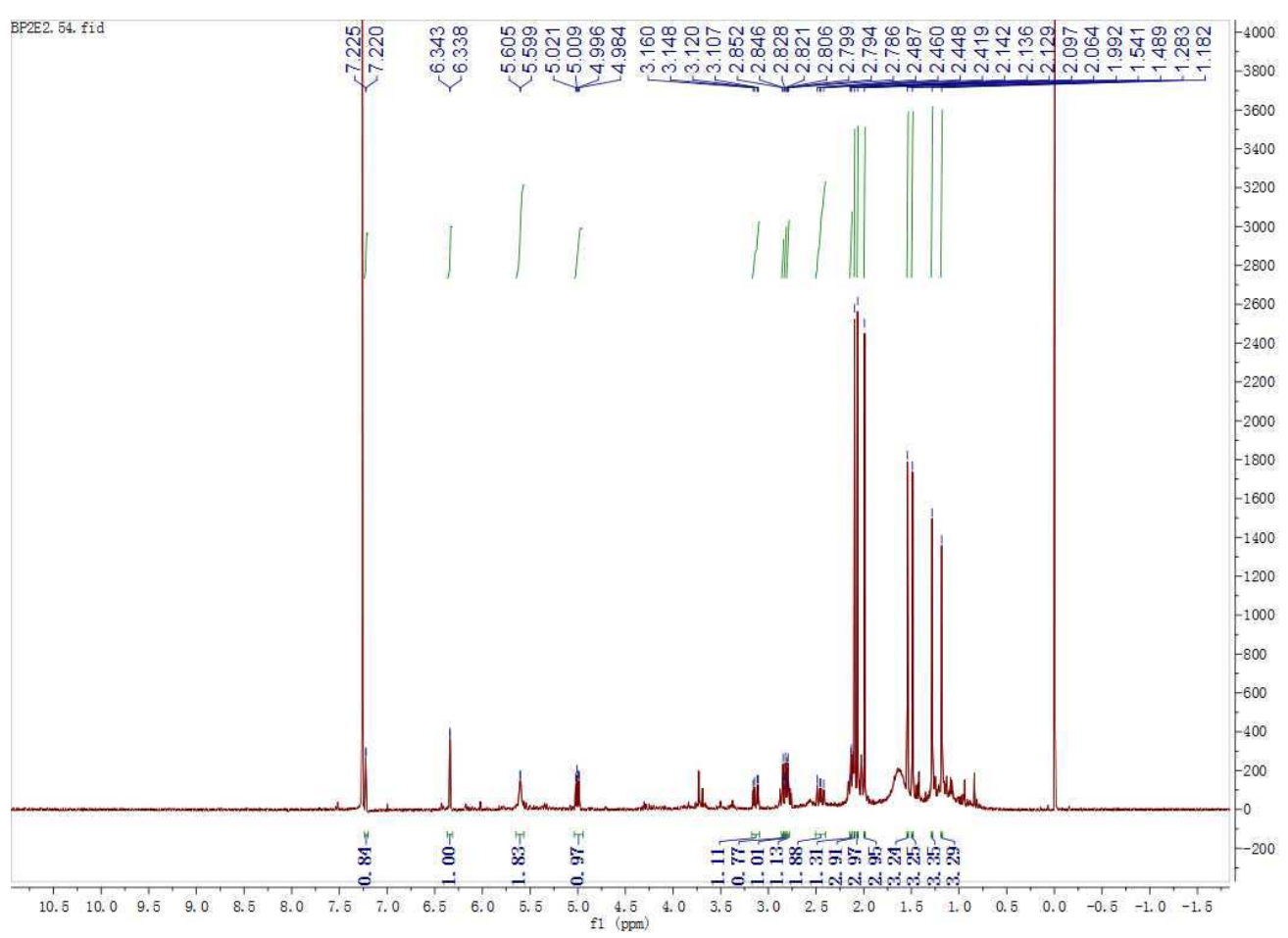

S29. The ${ }^{1} \mathrm{H}$ NMR (400 MHz, $\mathrm{CDCl}_{3}$ ) Spectrum of compound 5

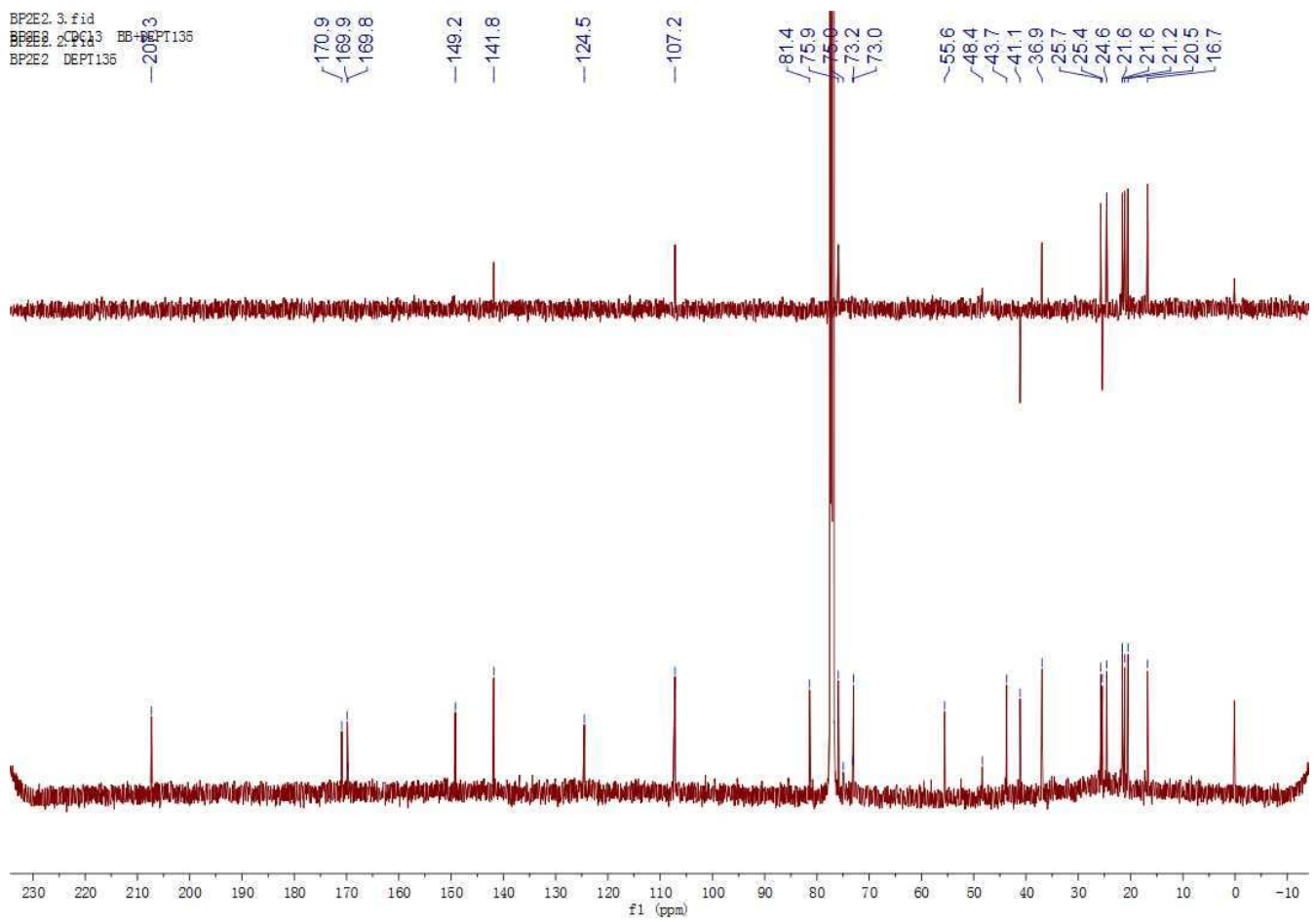

S30. The ${ }^{13} \mathrm{C}$ NMR (100 MHz, $\mathrm{CDCl}_{3}$ ) Spectrum of compound 5 


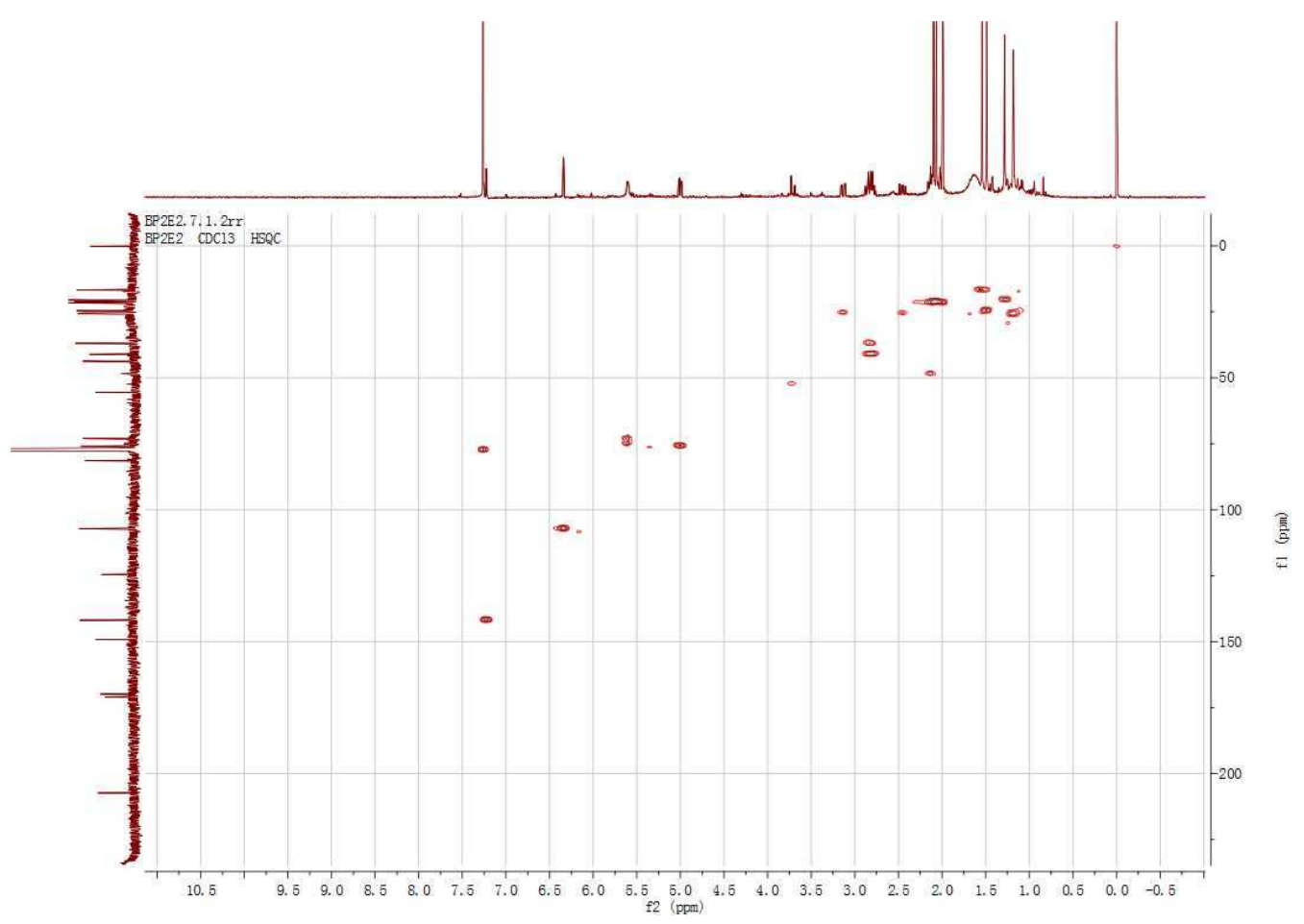

S31. The ${ }^{1} \mathrm{H}-{ }^{13} \mathrm{C}$ HMQC (400 MHz, $\mathrm{CDCl}_{3}$ ) Spectrum of compound 5

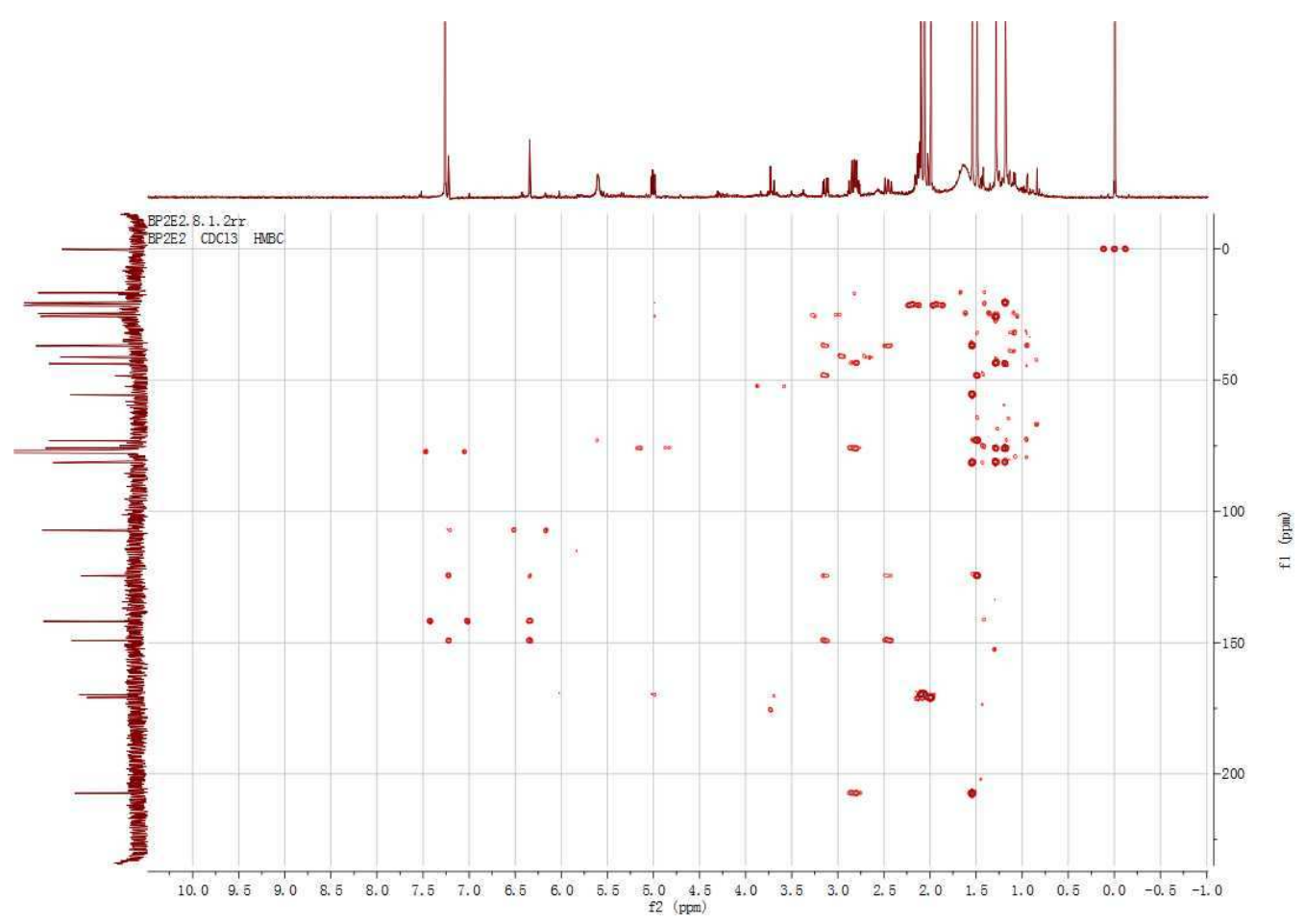

S32. The ${ }^{1} \mathrm{H}-{ }^{13} \mathrm{C}$ HMBC (400 MHz, $\mathrm{CDCl}_{3}$ ) Spectrum of compound 5 


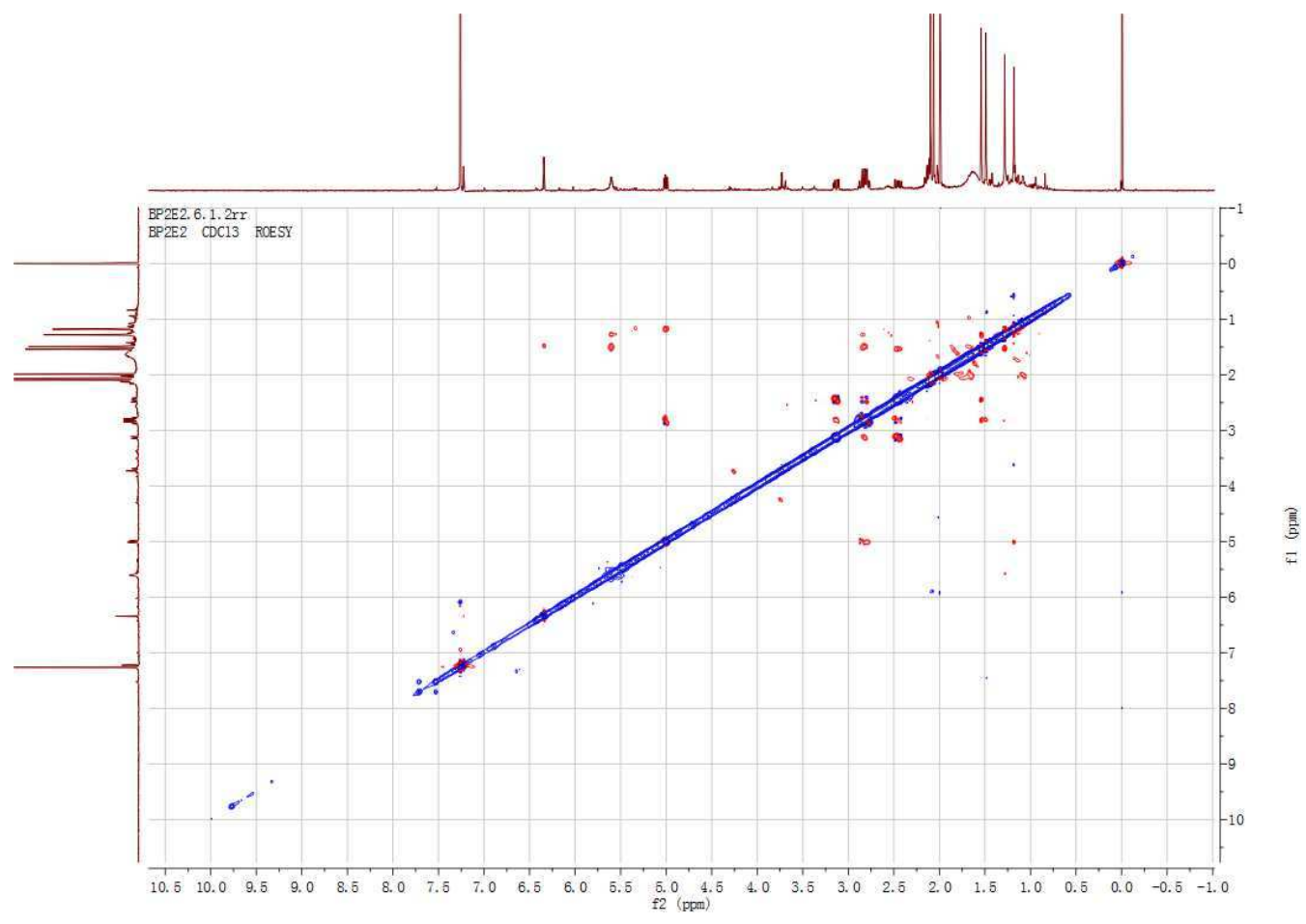

S33. The ${ }^{1} \mathrm{H}-{ }^{1} \mathrm{H}$ ROESY (400 MHz, $\mathrm{CDCl}_{3}$ ) Spectrum of compound 5

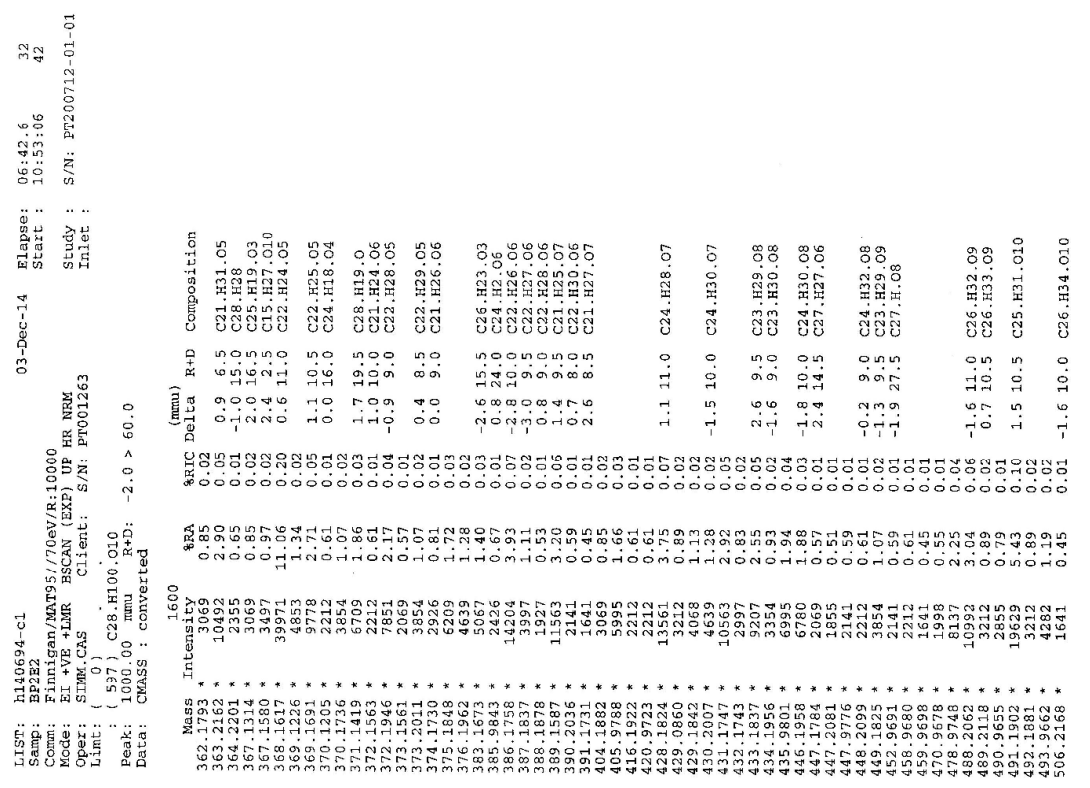

S34. The HR-EI-MS spectrum of compound 5 


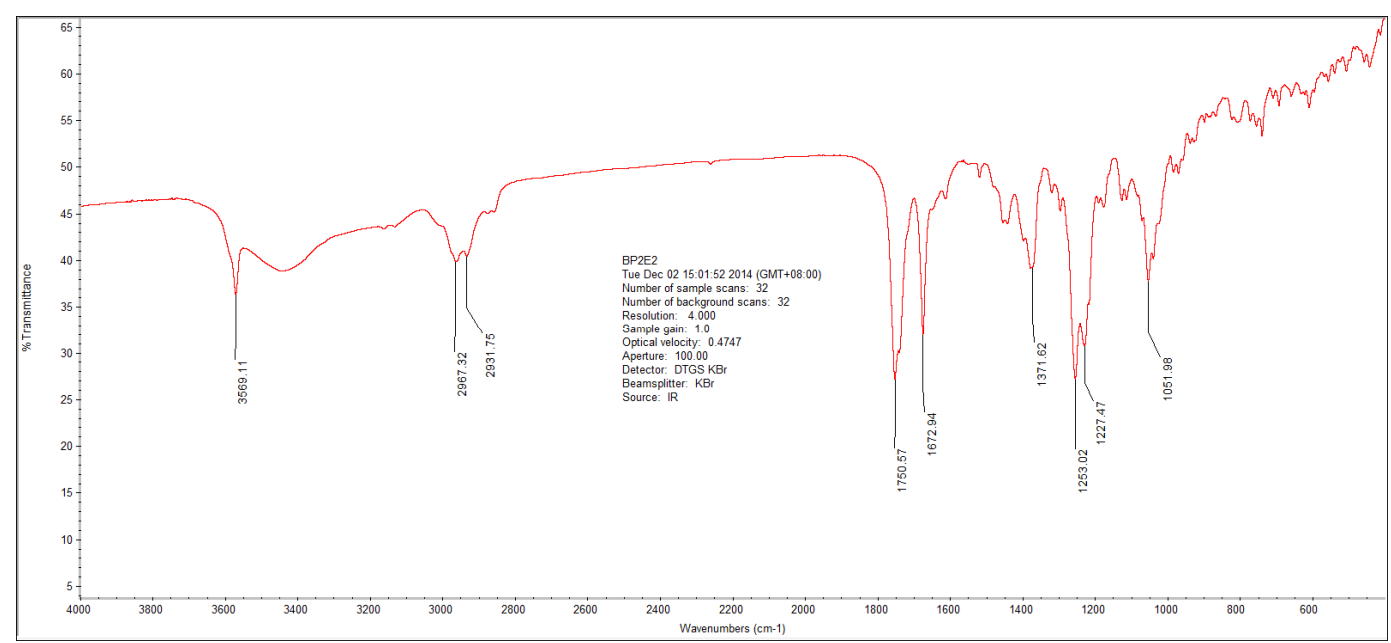

S35. The IR Spectrum of compound 5

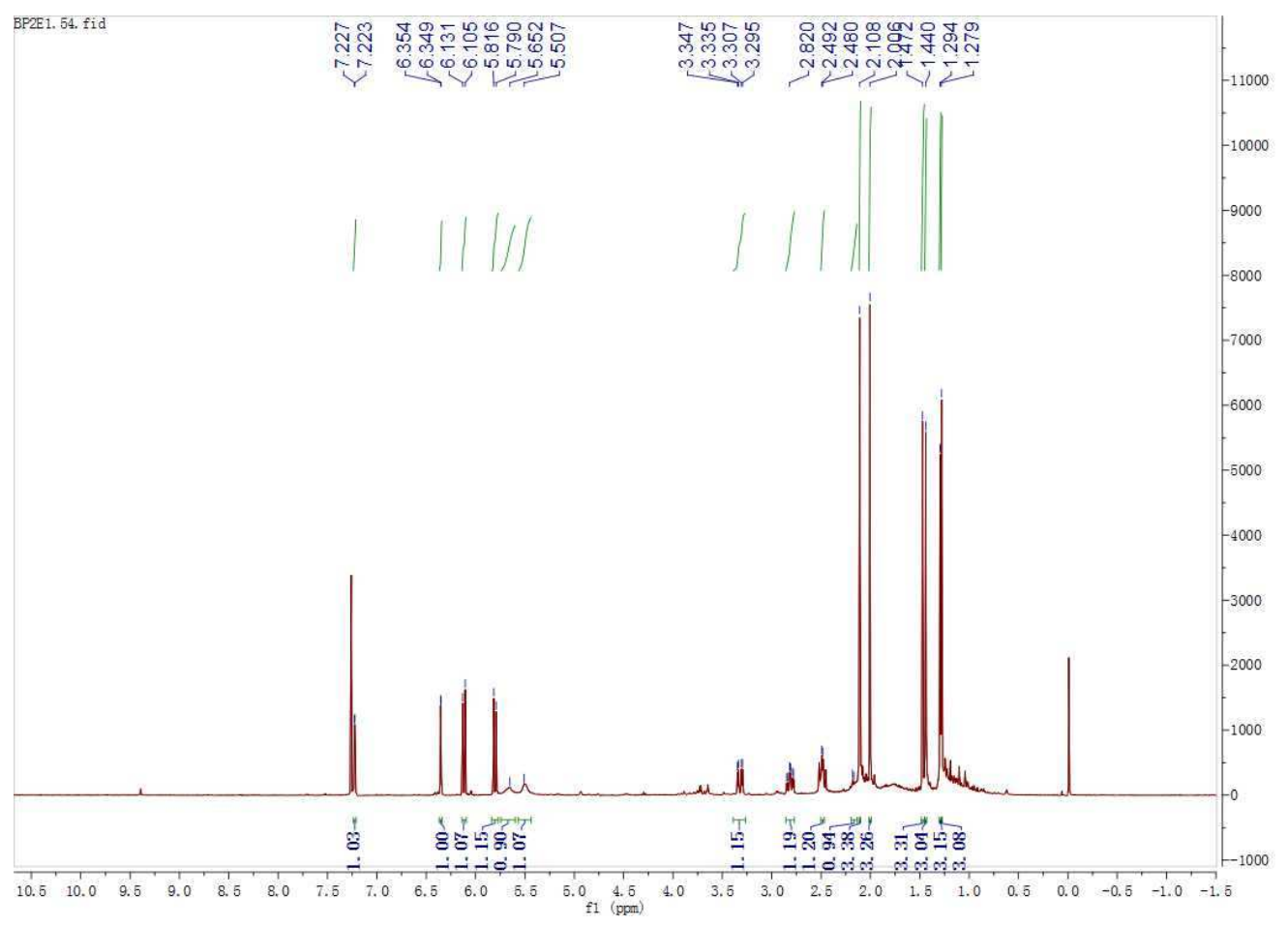

S36. The ${ }^{1} \mathrm{H}$ NMR (400 MHz, $\mathrm{CDCl}_{3}$ ) Spectrum of compound 6 


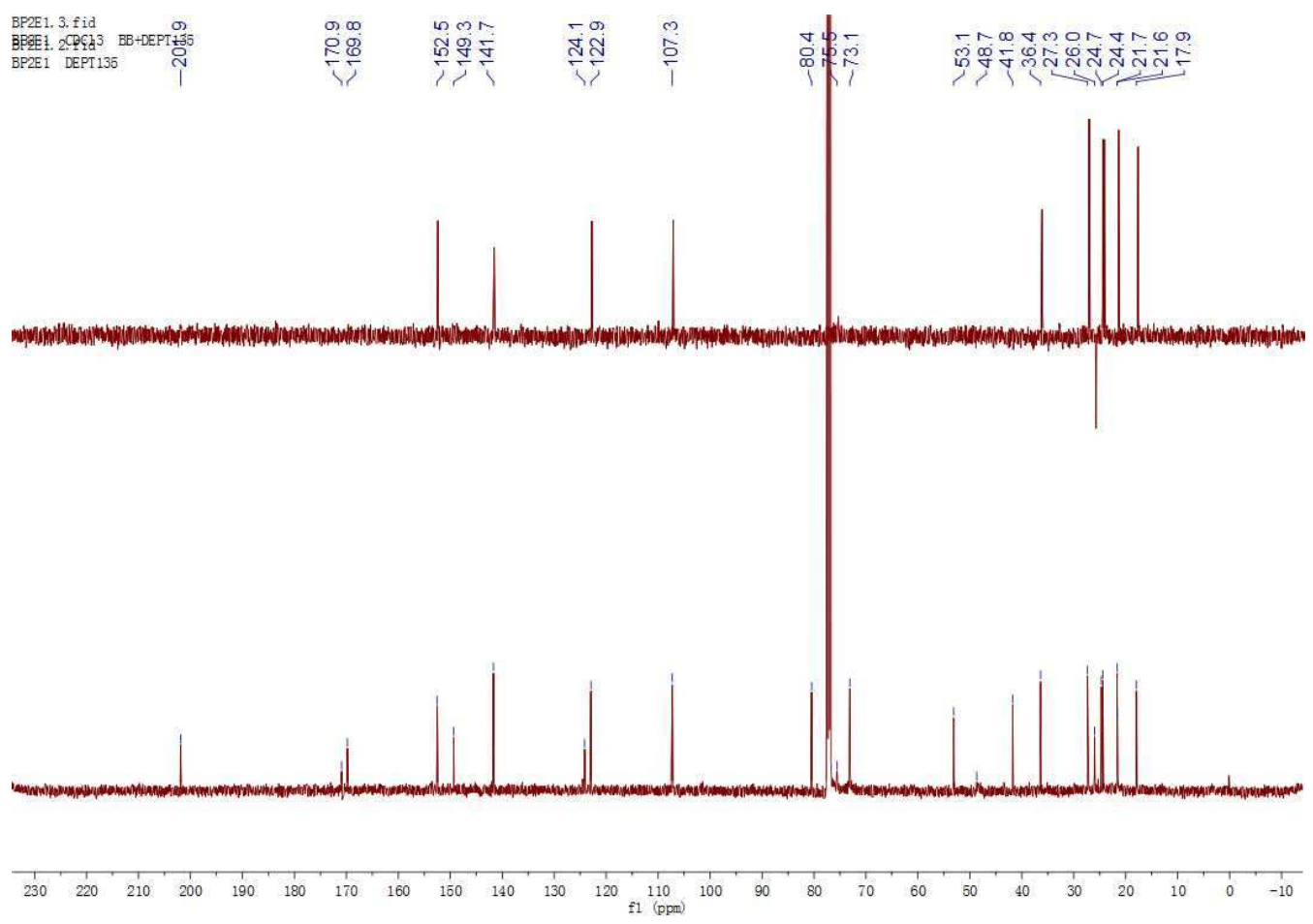

S37. The ${ }^{13} \mathrm{C}$ NMR (100 MHz, $\mathrm{CDCl}_{3}$ ) Spectrum of compound 6

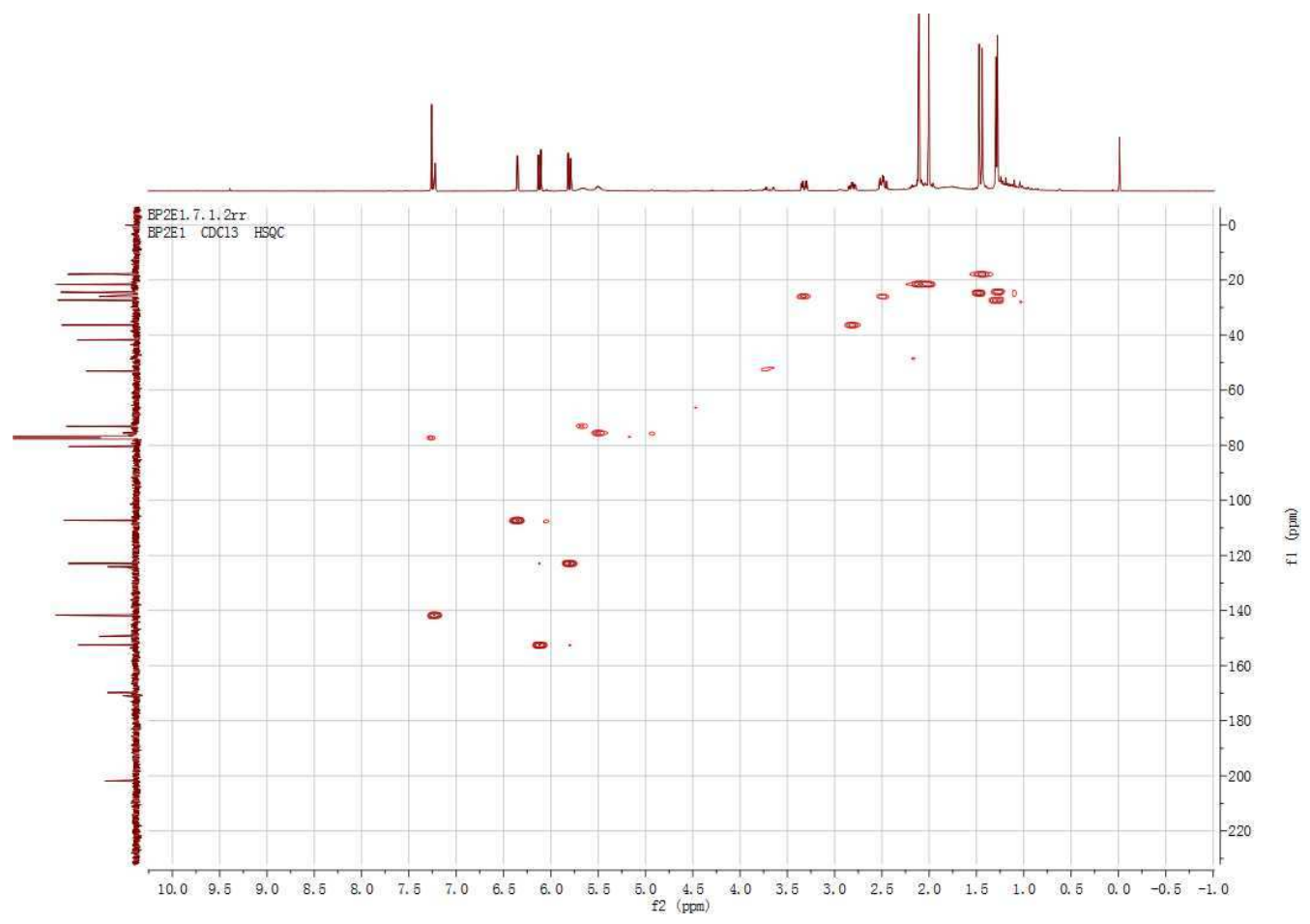

S38. The ${ }^{1} \mathrm{H}-{ }^{13} \mathrm{C}$ HMQC (400 MHz, $\mathrm{CDCl}_{3}$ ) Spectrum of compound 6 


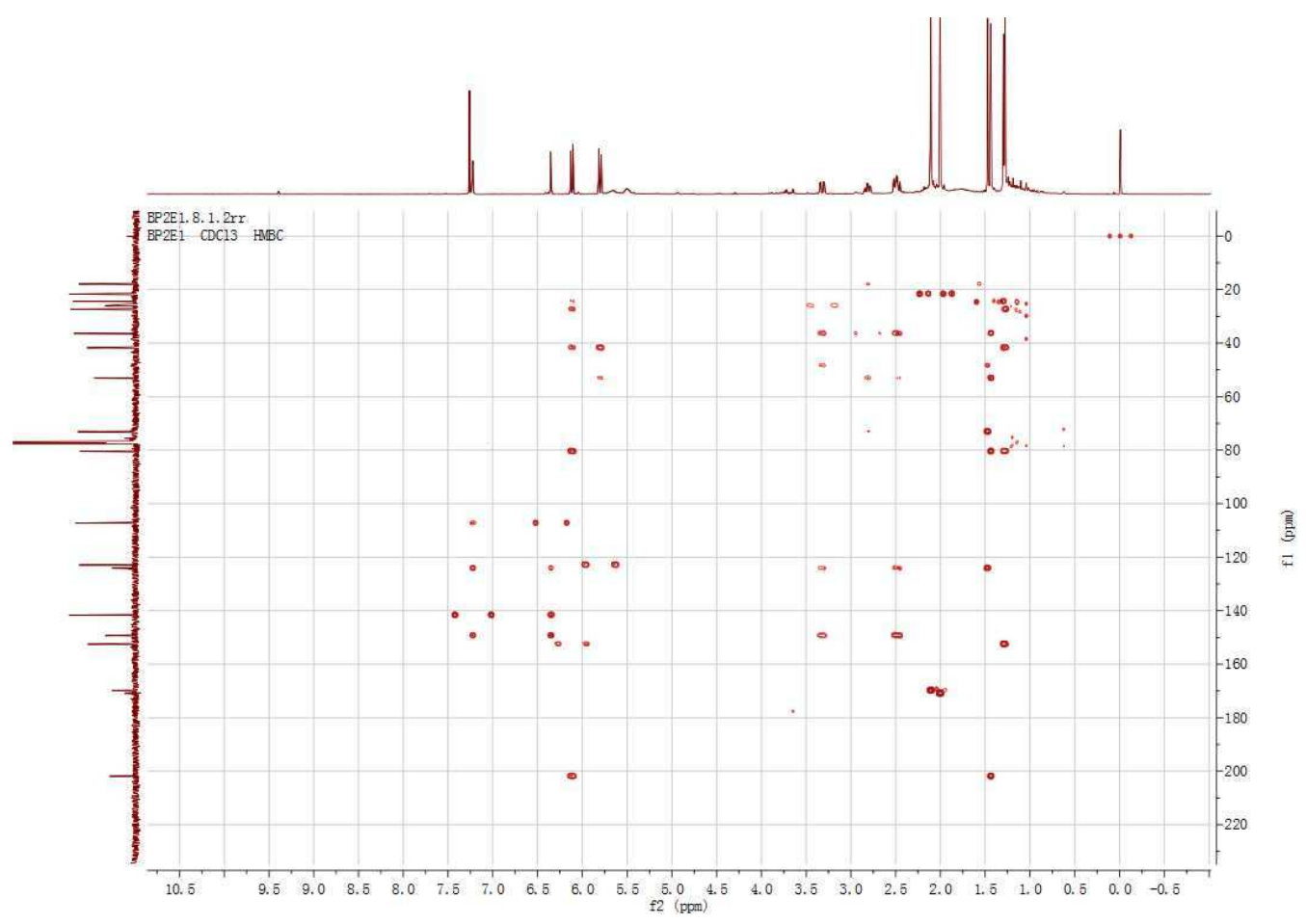

S39. The ${ }^{1} \mathrm{H}-{ }^{13} \mathrm{C} \mathrm{HMBC}\left(400 \mathrm{MHz}, \mathrm{CDCl}_{3}\right.$ ) Spectrum of compound 6

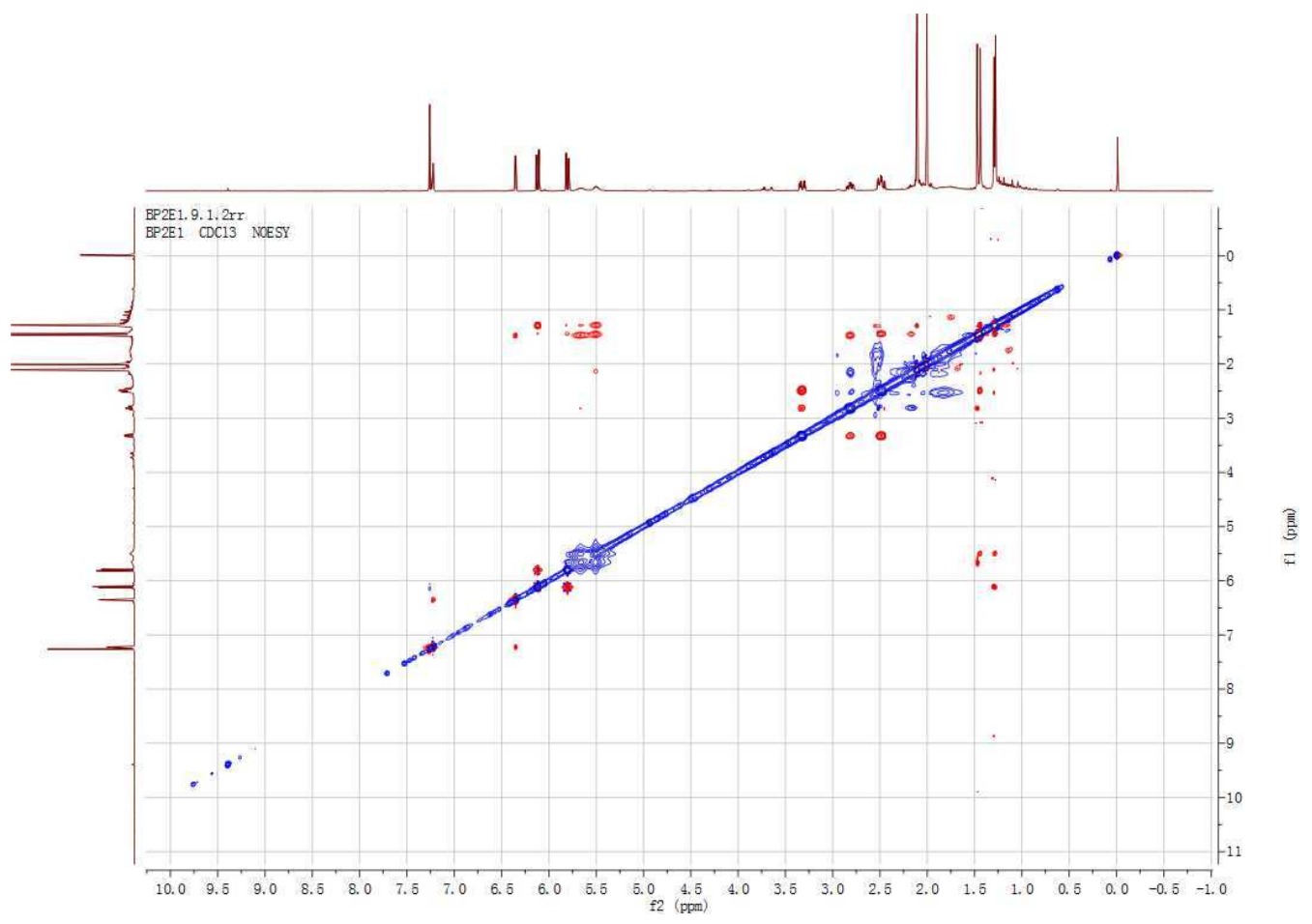

S40. The ${ }^{1} \mathrm{H}-{ }^{1} \mathrm{H}$ ROESY (400 MHz, $\mathrm{CDCl}_{3}$ ) Spectrum of compound 6 


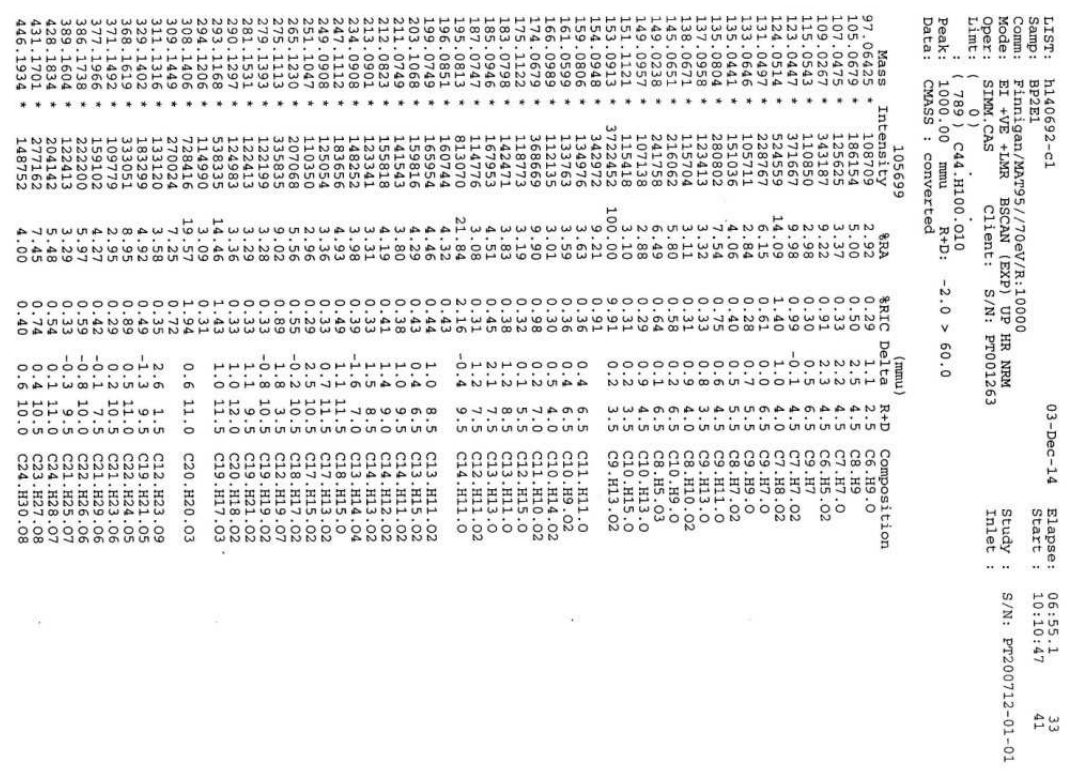

\section{S41. The HR-EI-MS spectrum of compound $\mathbf{6}$}

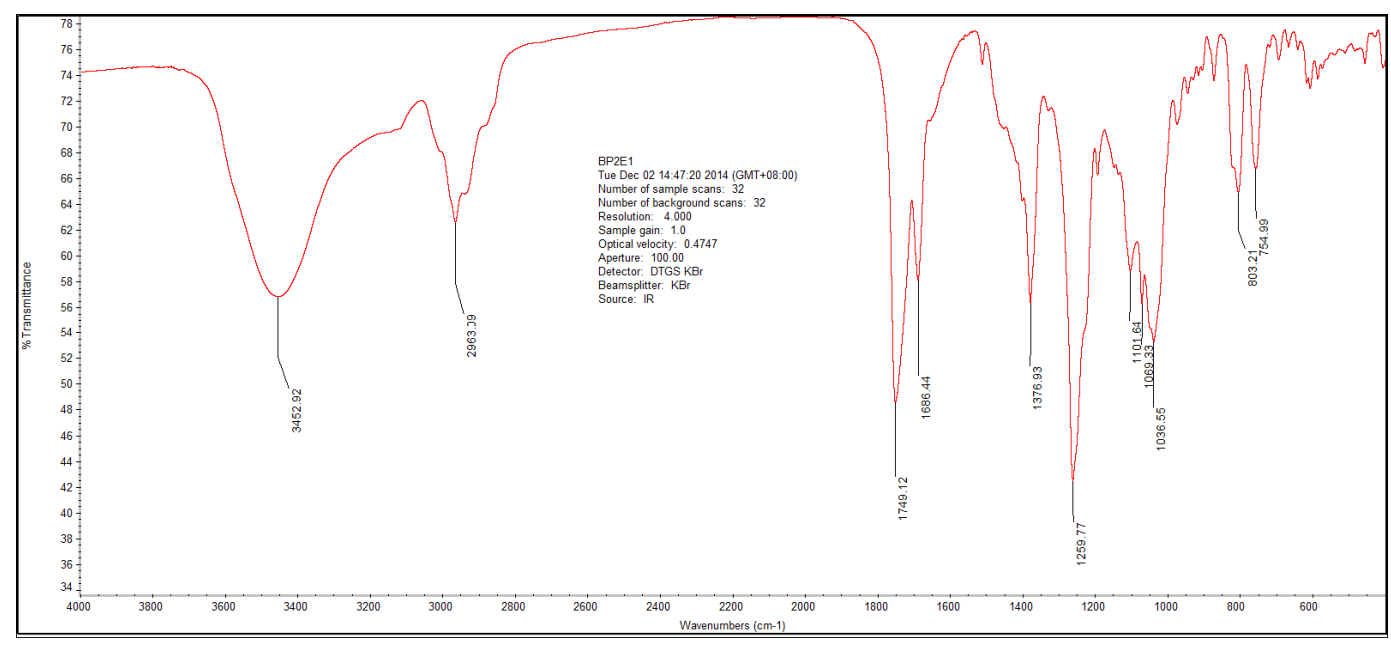

S42. The IR Spectrum of compound 6 


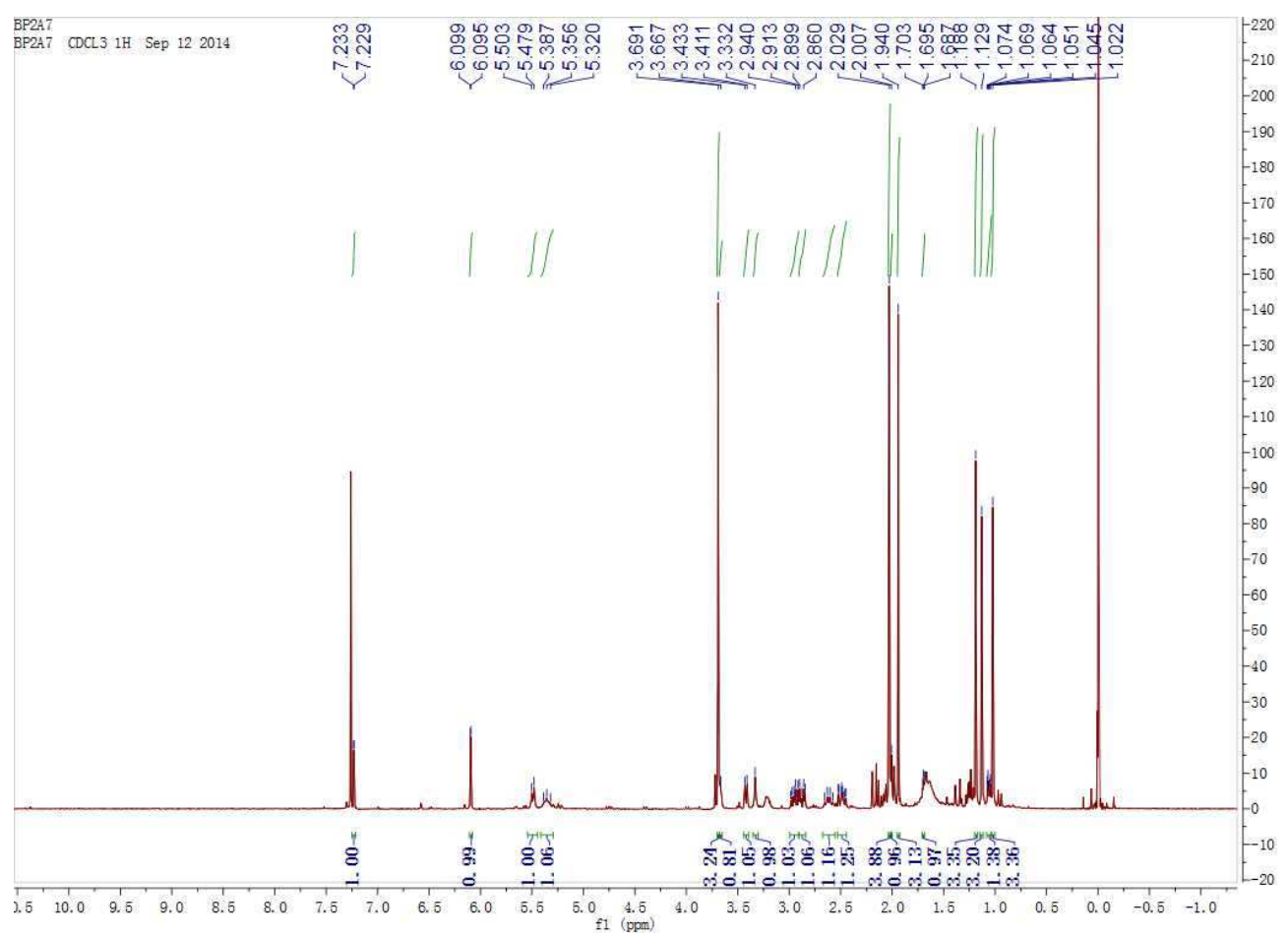

S43. The ${ }^{1} \mathrm{H}$ NMR (400 MHz, $\mathrm{CDCl}_{3}$ ) Spectrum of compound 7

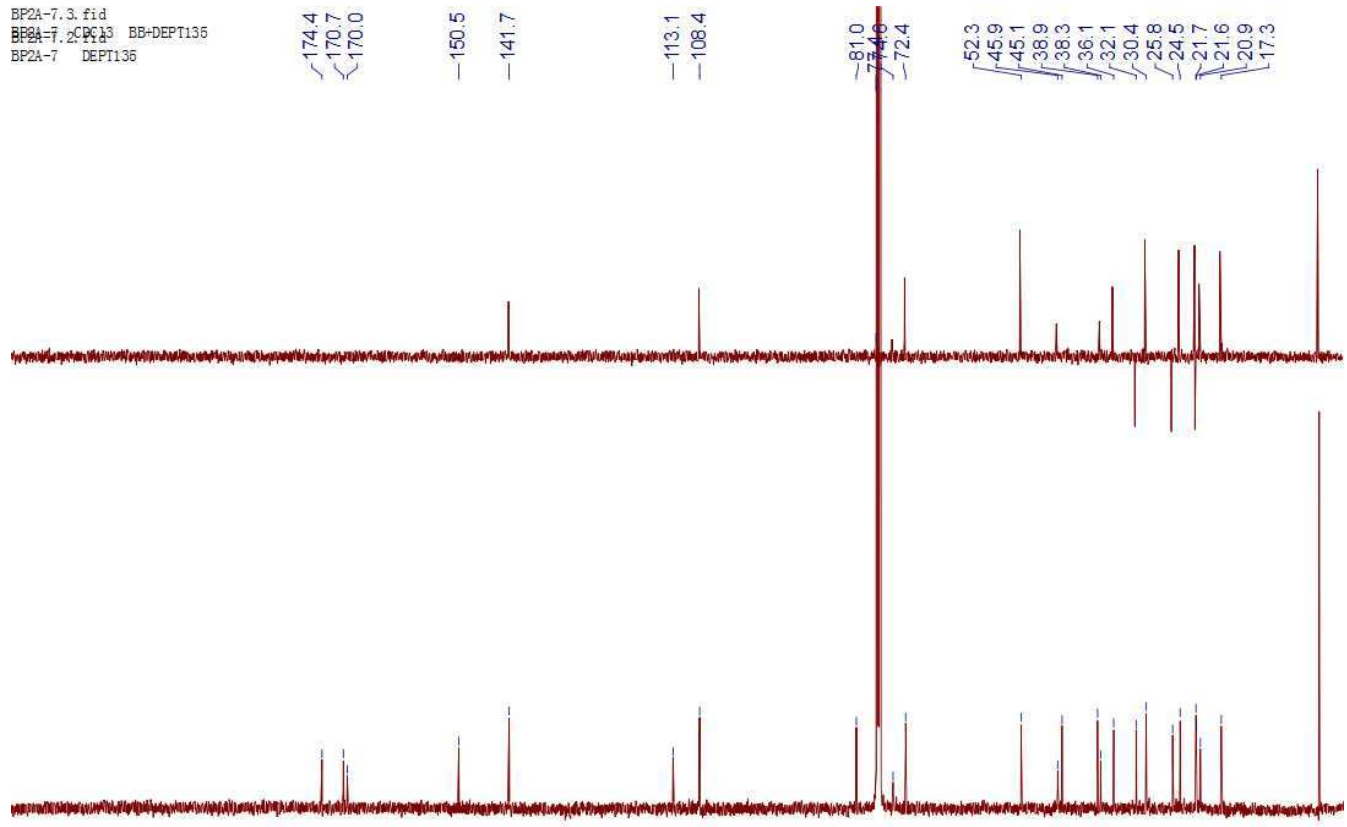

$\begin{array}{llllllllllll}220 & 210 & 200 & 190 & 180 & 170 & 160 & 150 & 140 & 130 & 120 & 110 \\ \mathrm{f} 1 & (\mathrm{ppm})\end{array}$

S44. The ${ }^{13} \mathrm{C}$ NMR (100 MHz, $\mathrm{CDCl}_{3}$ ) Spectrum of compound 7 


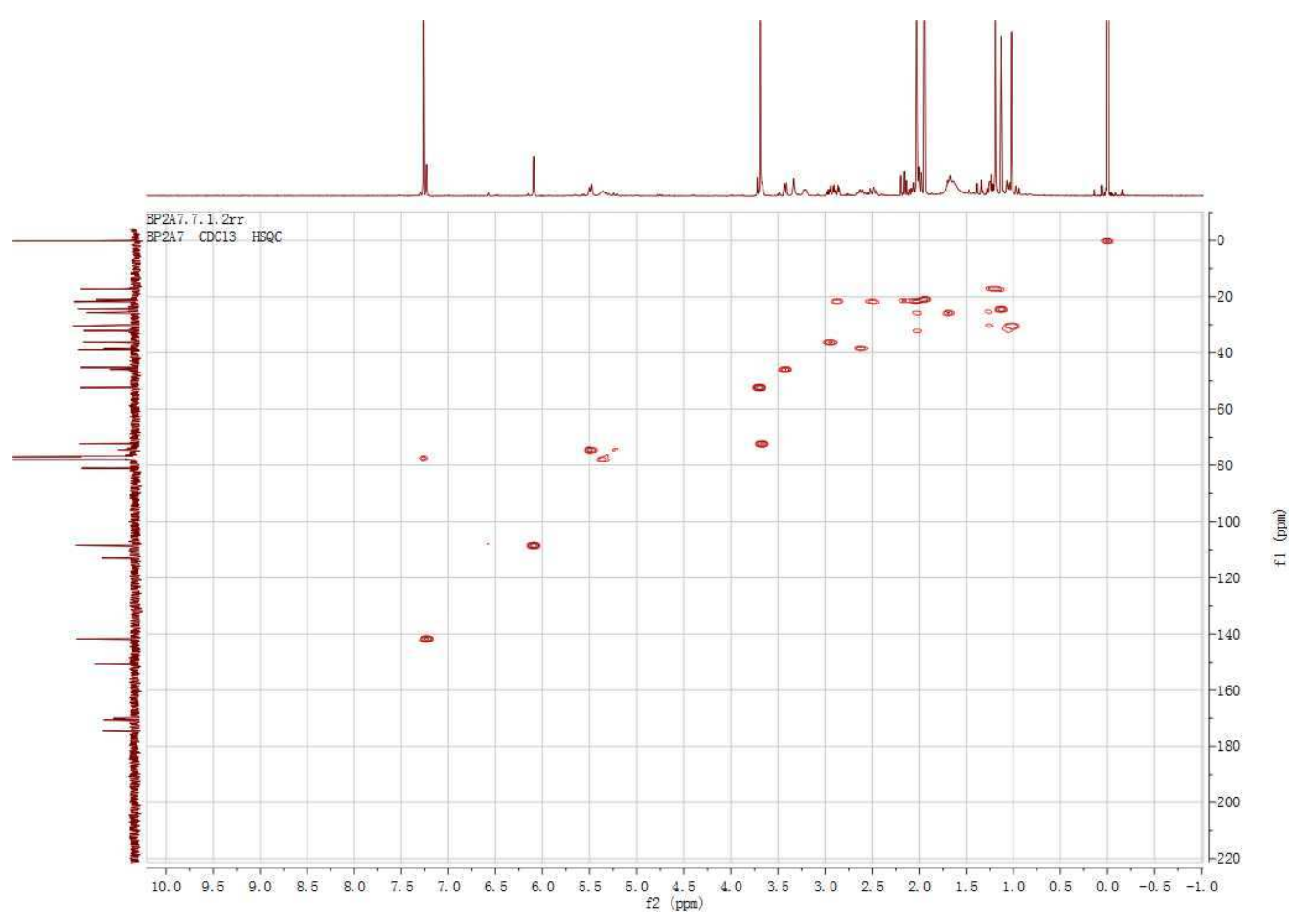

S45. The ${ }^{1} \mathrm{H}-{ }^{13} \mathrm{C}$ HMQC (400 MHz, $\mathrm{CDCl}_{3}$ ) Spectrum of compound 7

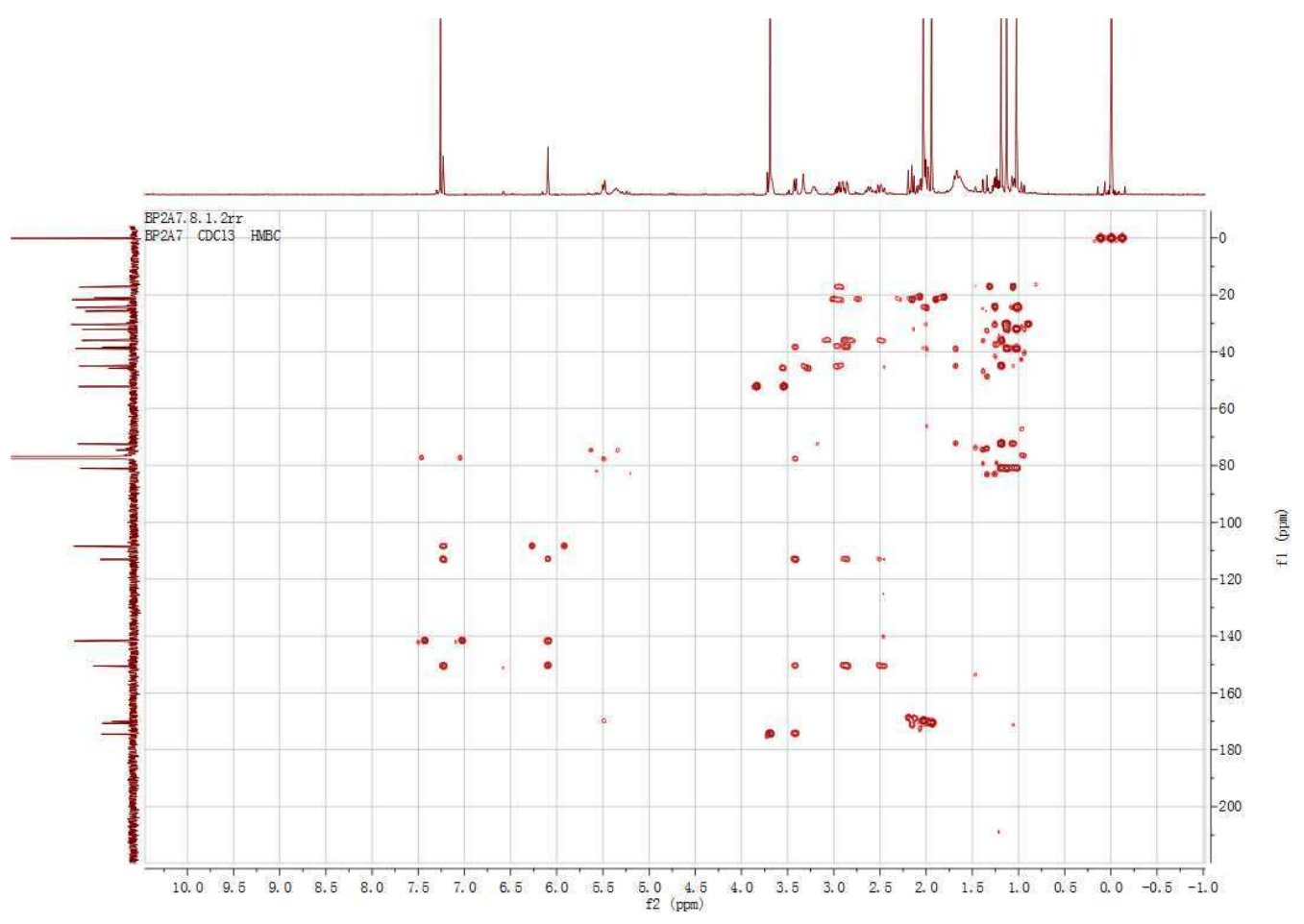

S46. The ${ }^{1} \mathrm{H}-{ }^{13} \mathrm{C}$ HMBC (400 MHz, $\mathrm{CDCl}_{3}$ ) Spectrum of compound 7 


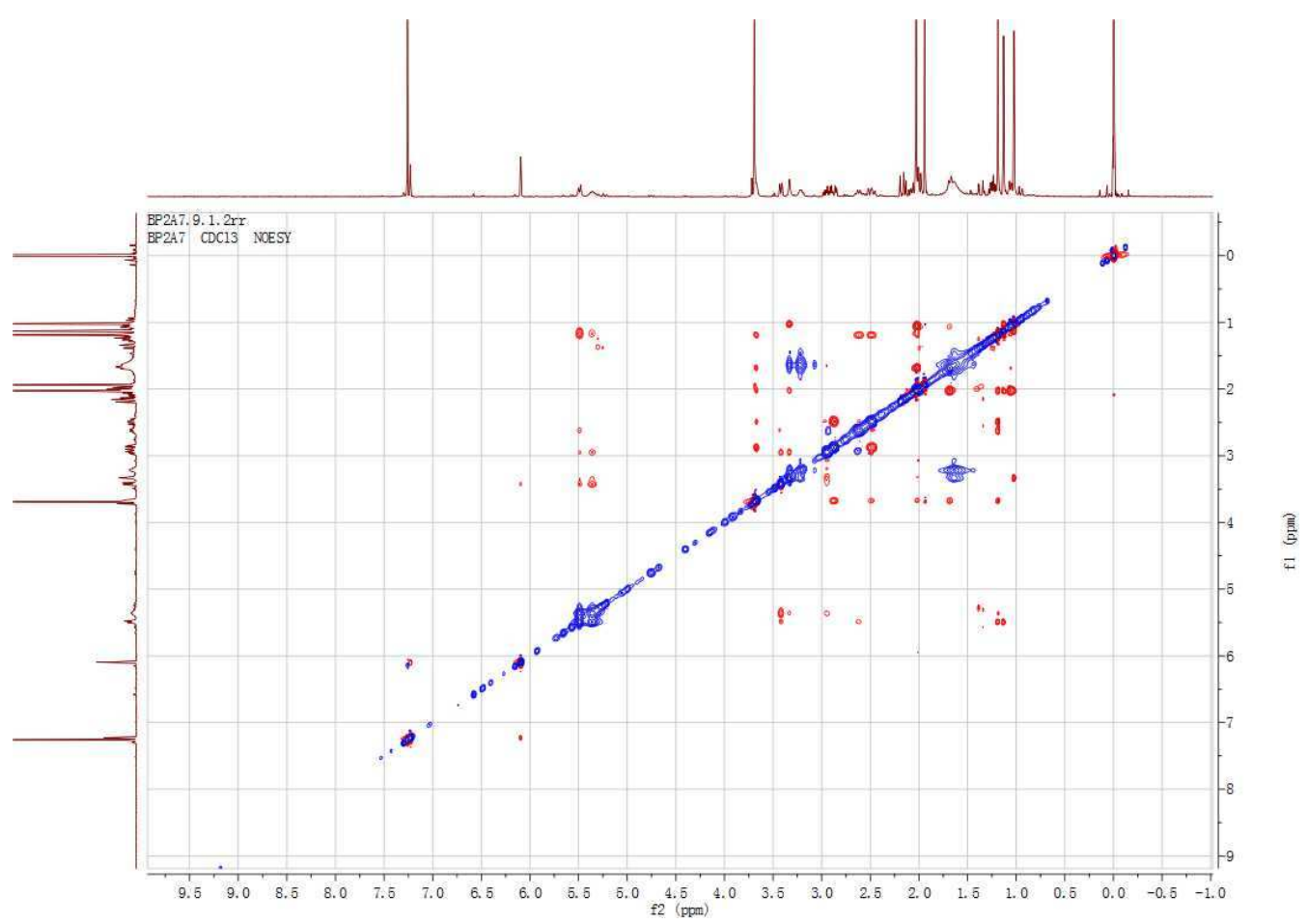

S47. The ${ }^{1} \mathrm{H}-{ }^{1} \mathrm{H}$ ROESY (400 MHz, $\mathrm{CDCl}_{3}$ ) Spectrum of compound 7

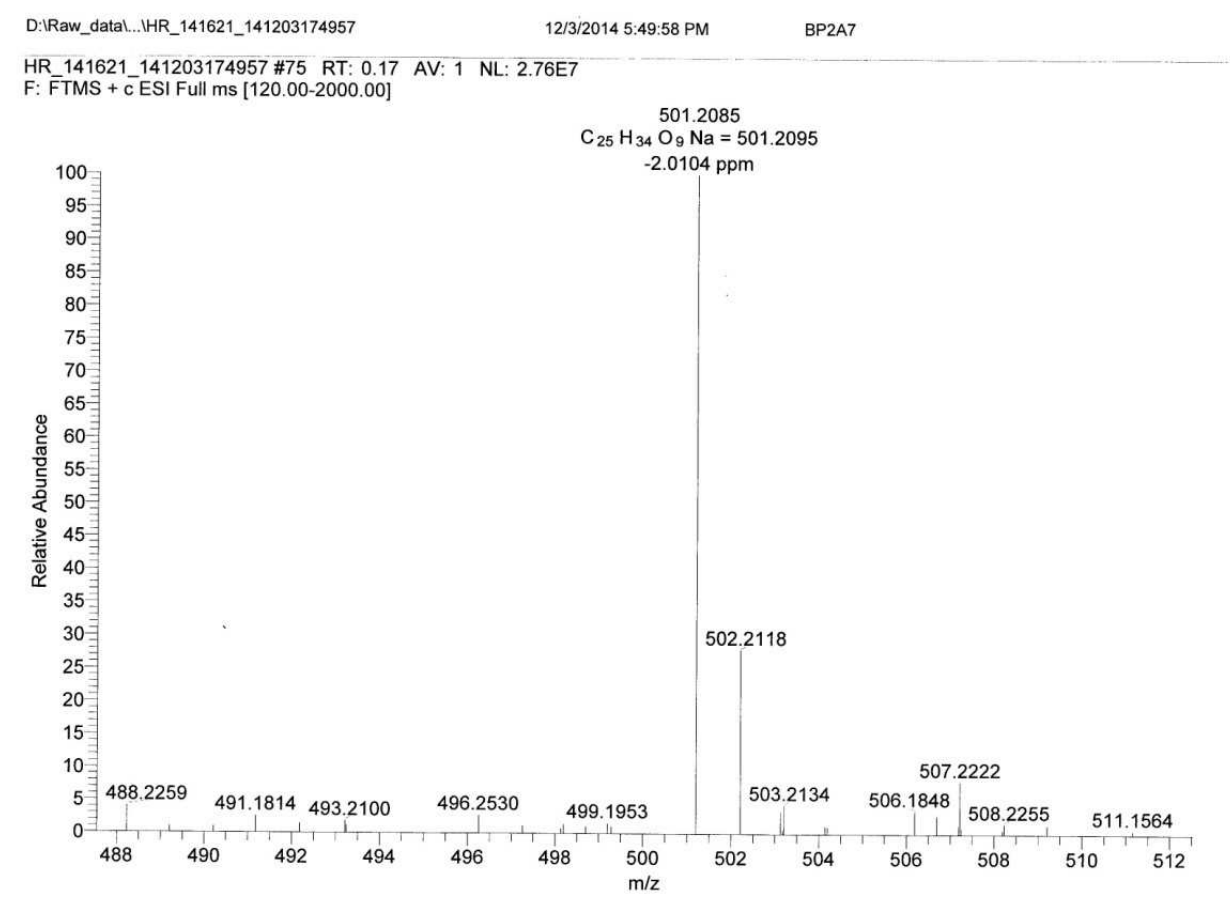

S48. The HR-ESI-MS spectrum of compound 7 


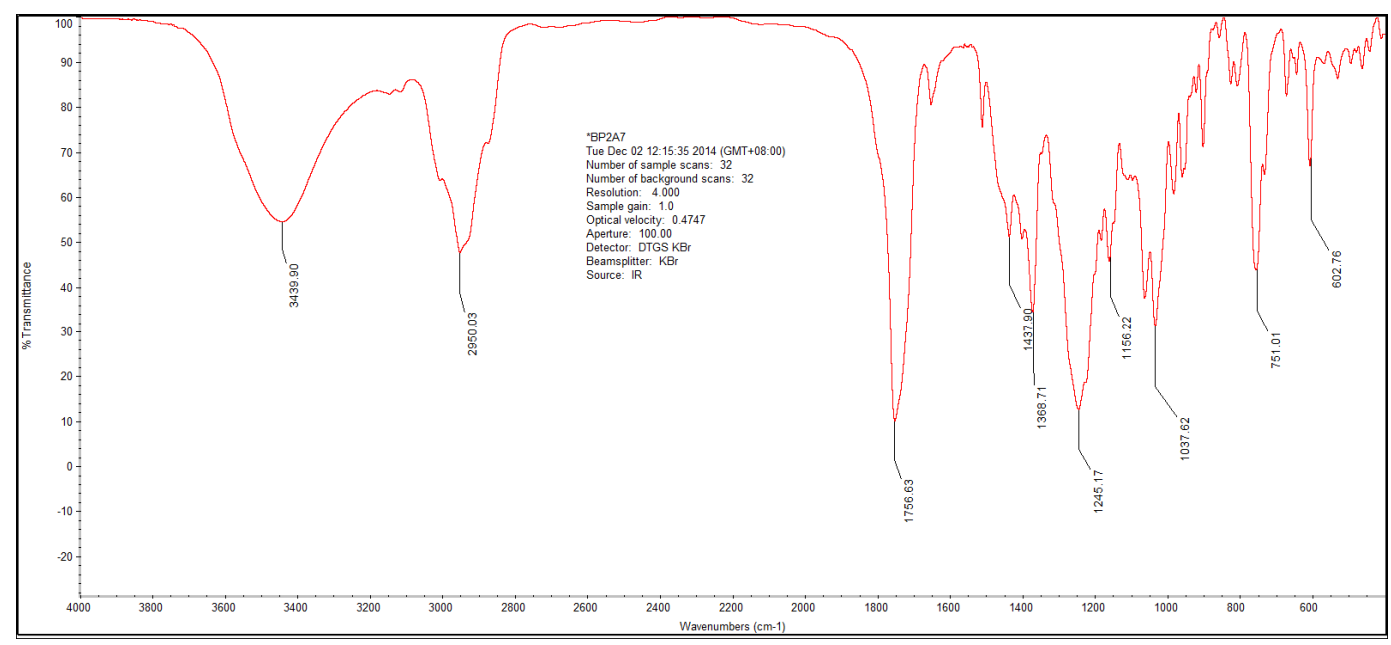

S49. The IR Spectrum of compound 7

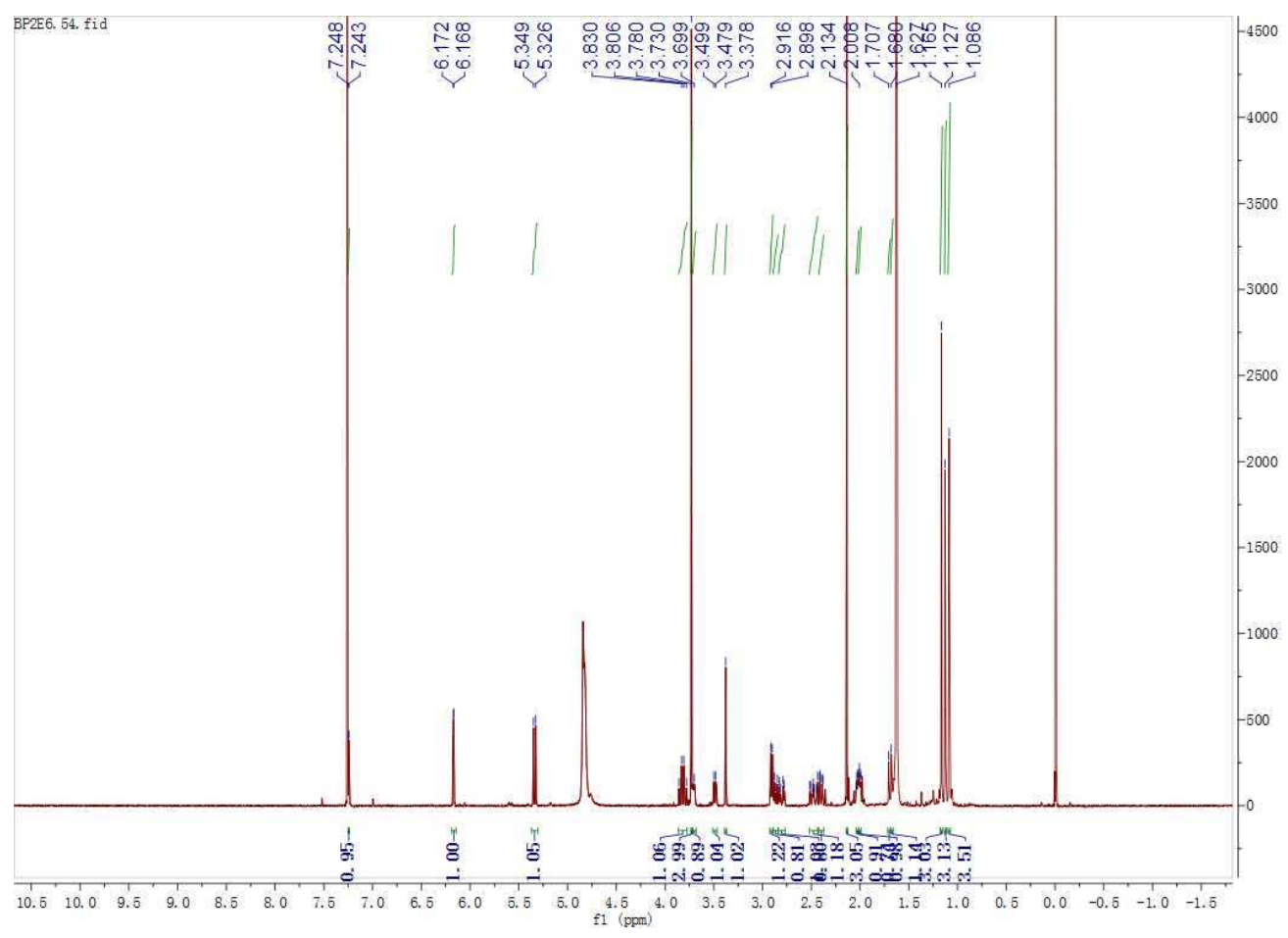

S50. The ${ }^{1} \mathrm{H}$ NMR (400 MHz, $\mathrm{CDCl}_{3}$ ) Spectrum of compound 8 


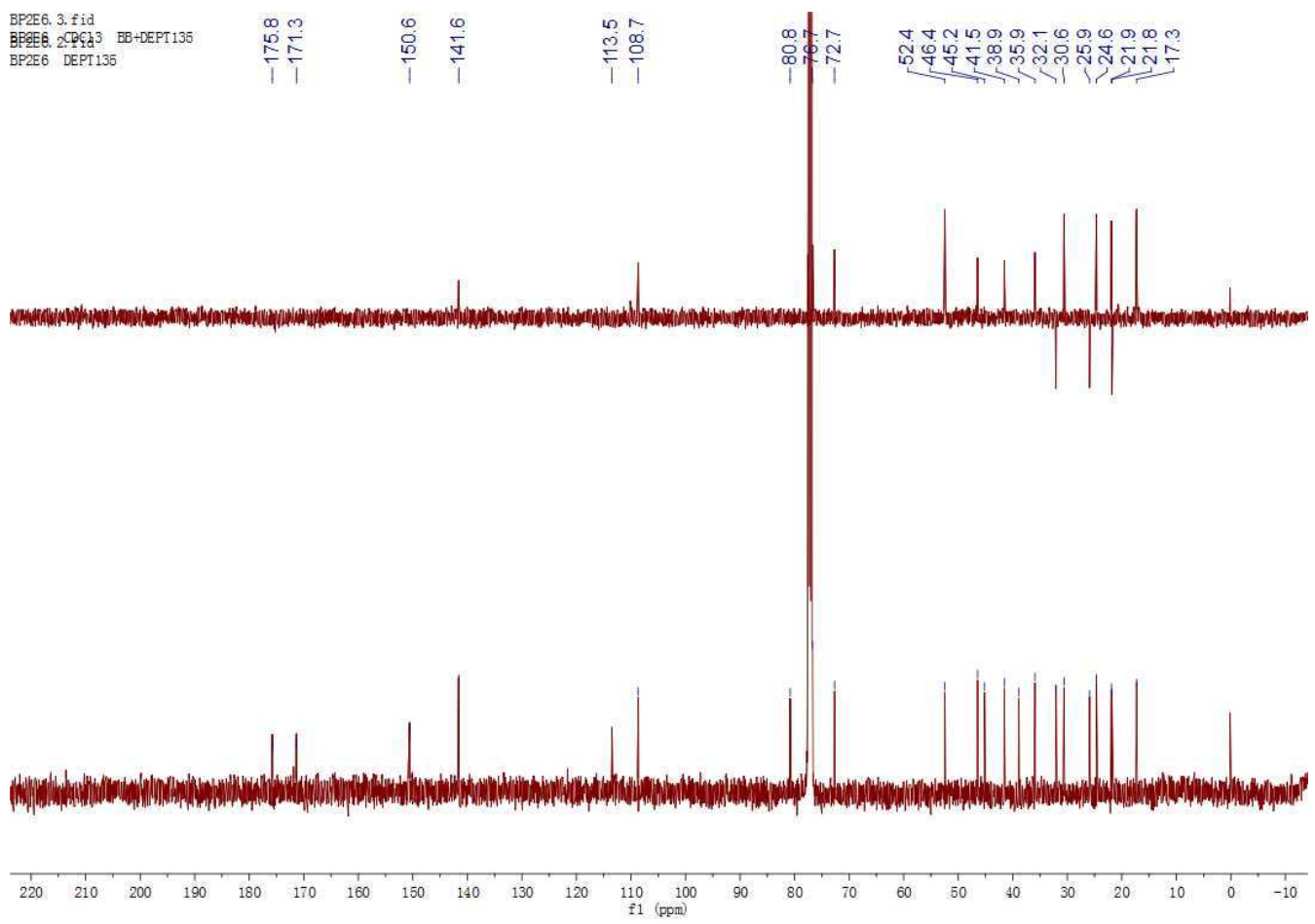

S51. The ${ }^{13} \mathrm{C}$ NMR (100 MHz, $\mathrm{CDCl}_{3}$ ) Spectrum of compound 8

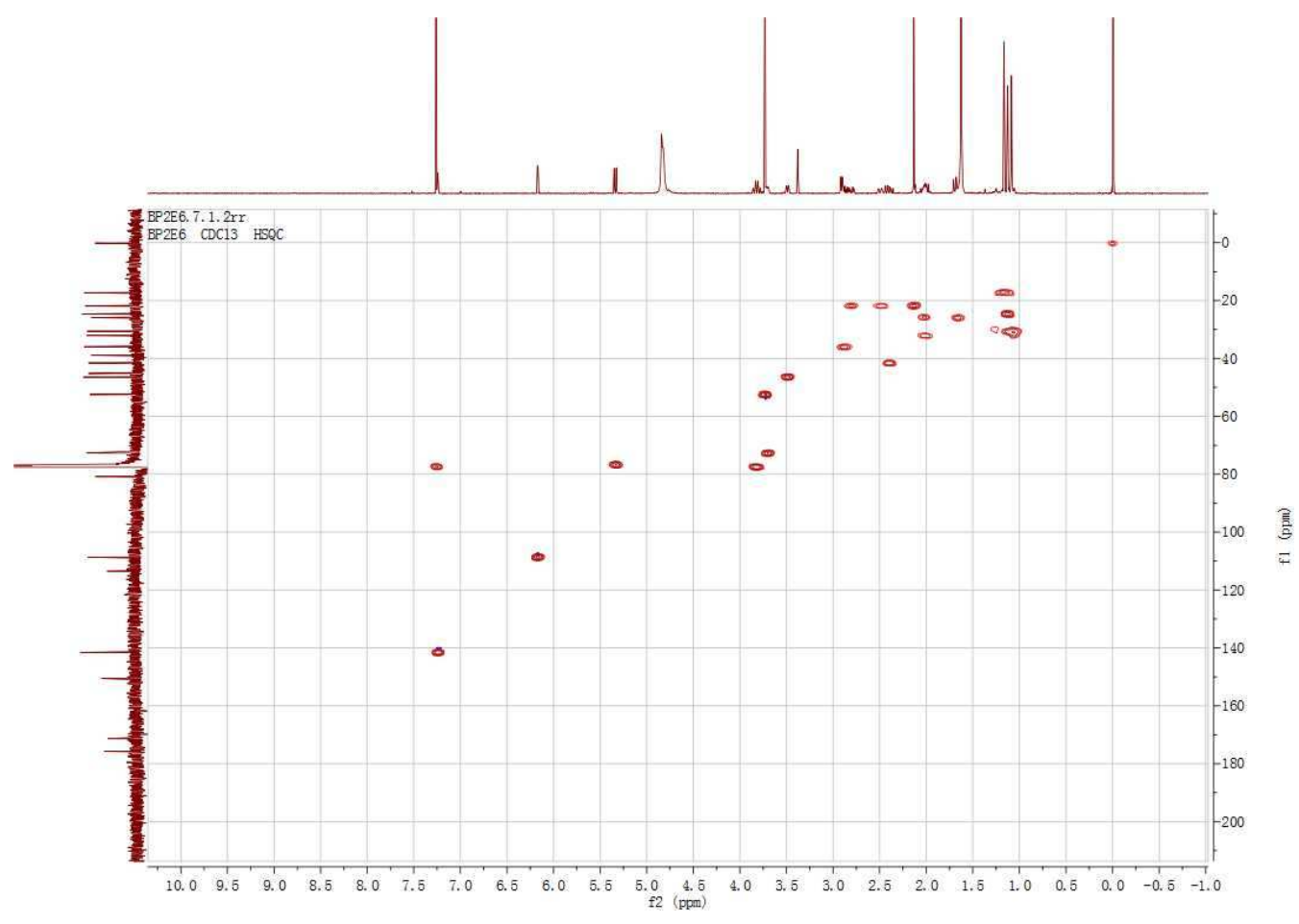

S52. The ${ }^{1} \mathrm{H}-{ }^{13} \mathrm{C}$ HMQC (400 MHz, $\mathrm{CDCl}_{3}$ ) Spectrum of compound 8 


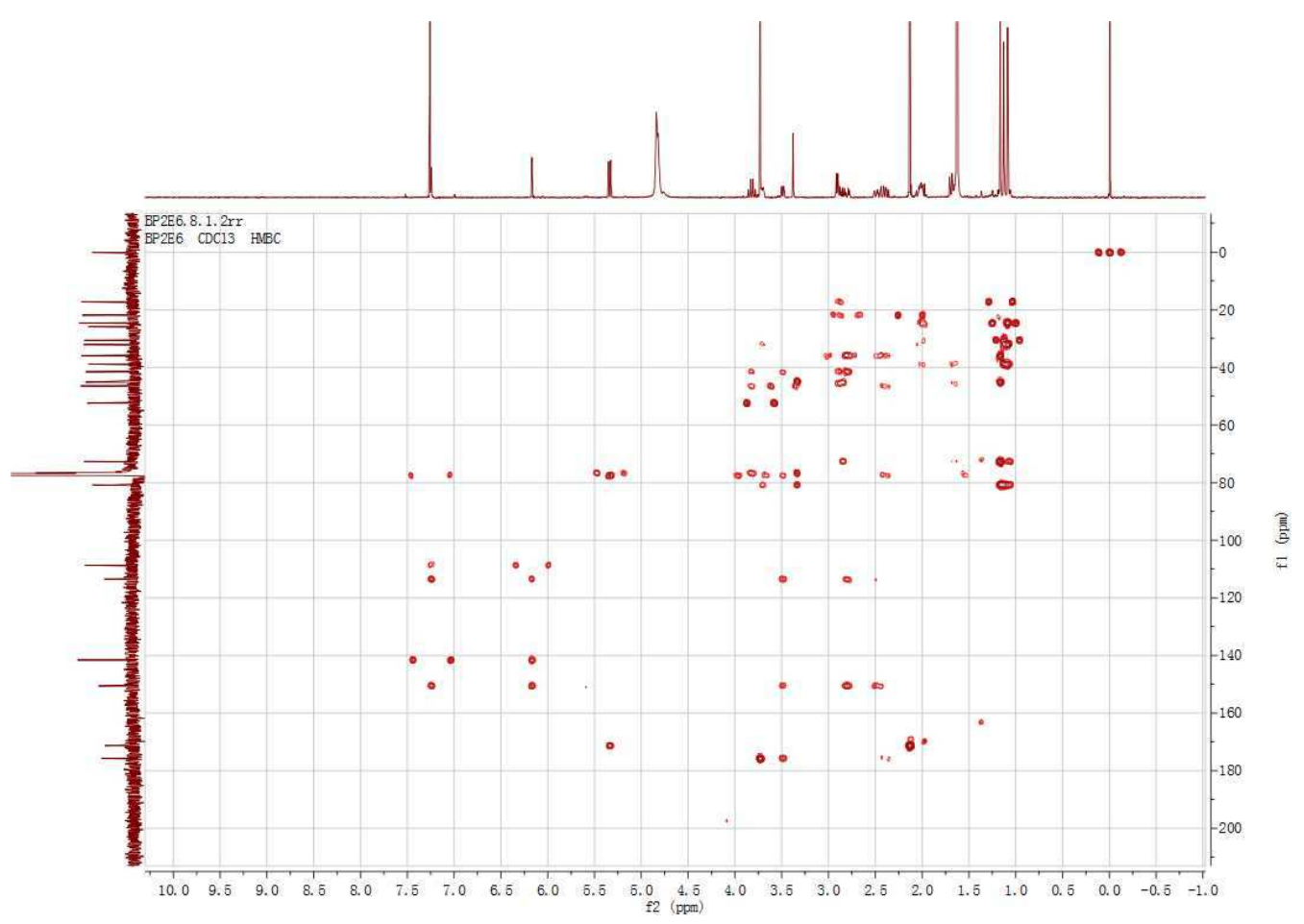

S53. The ${ }^{1} \mathrm{H}-{ }^{13} \mathrm{C}$ HMBC (400 MHz, $\mathrm{CDCl}_{3}$ ) Spectrum of compound 8

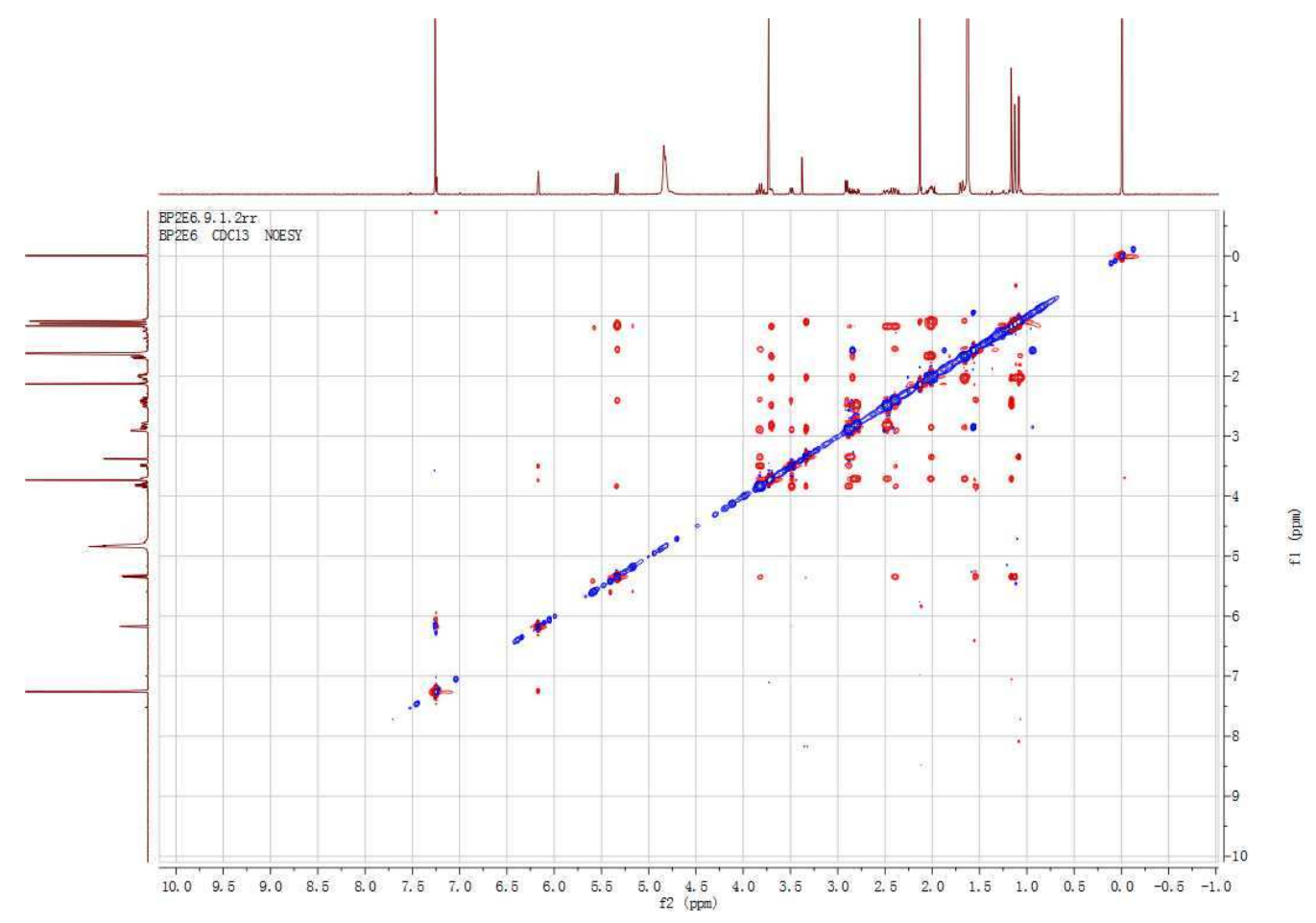

S54. The ${ }^{1} \mathrm{H}-{ }^{1} \mathrm{H}$ ROESY (400 MHz, $\mathrm{CDCl}_{3}$ ) Spectrum of compound 8 


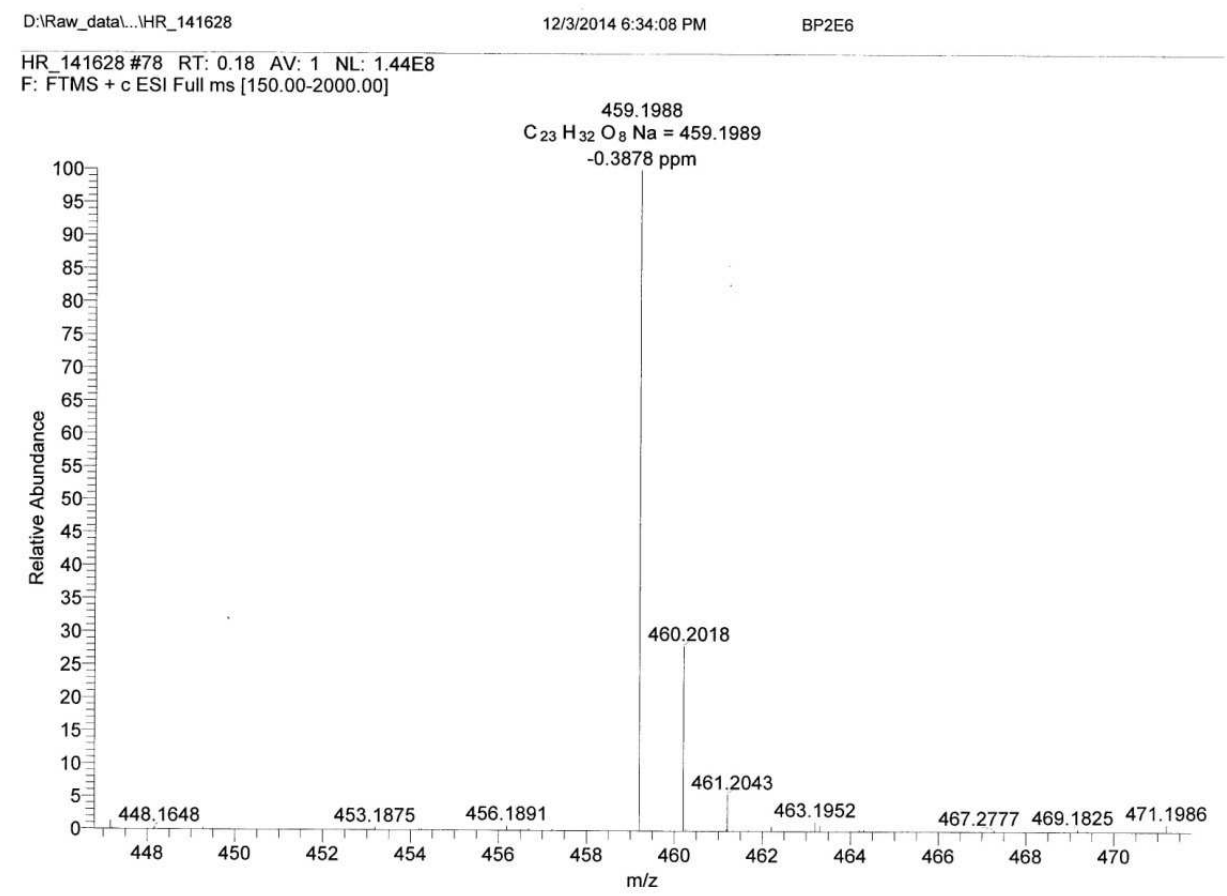

S55. The HR-ESI-MS spectrum of compound $\mathbf{8}$

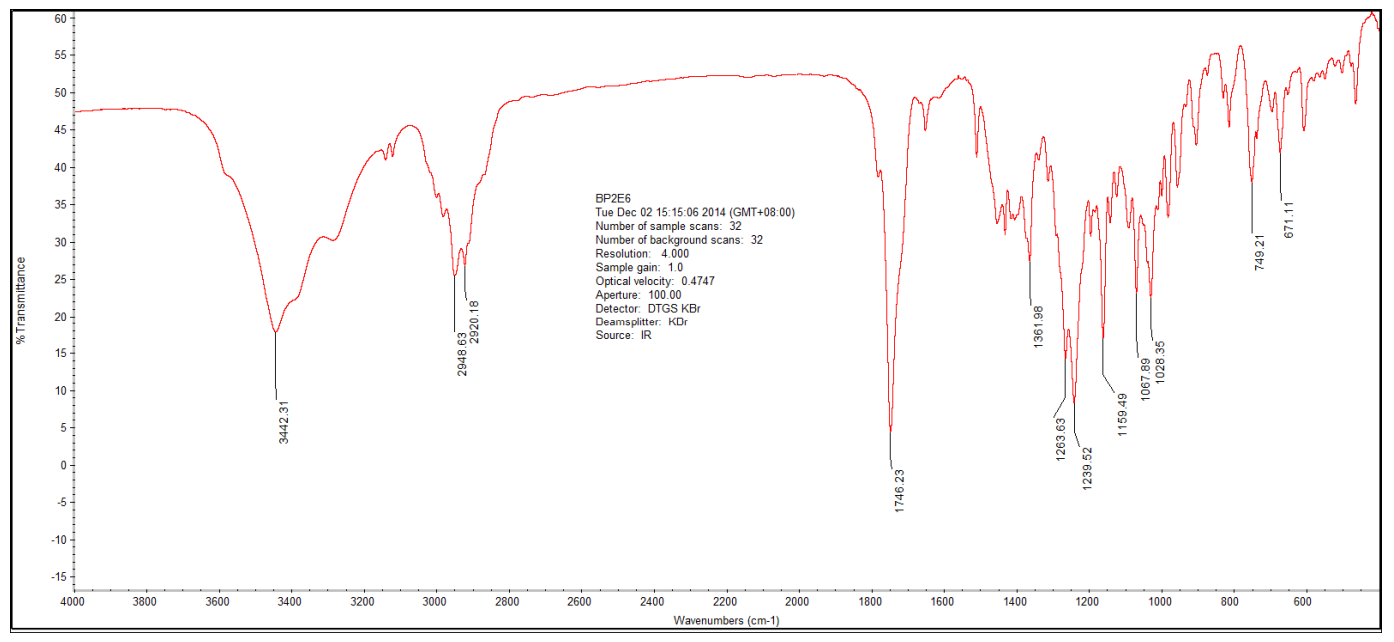

S56. The IR Spectrum of compound $\mathbf{8}$ 


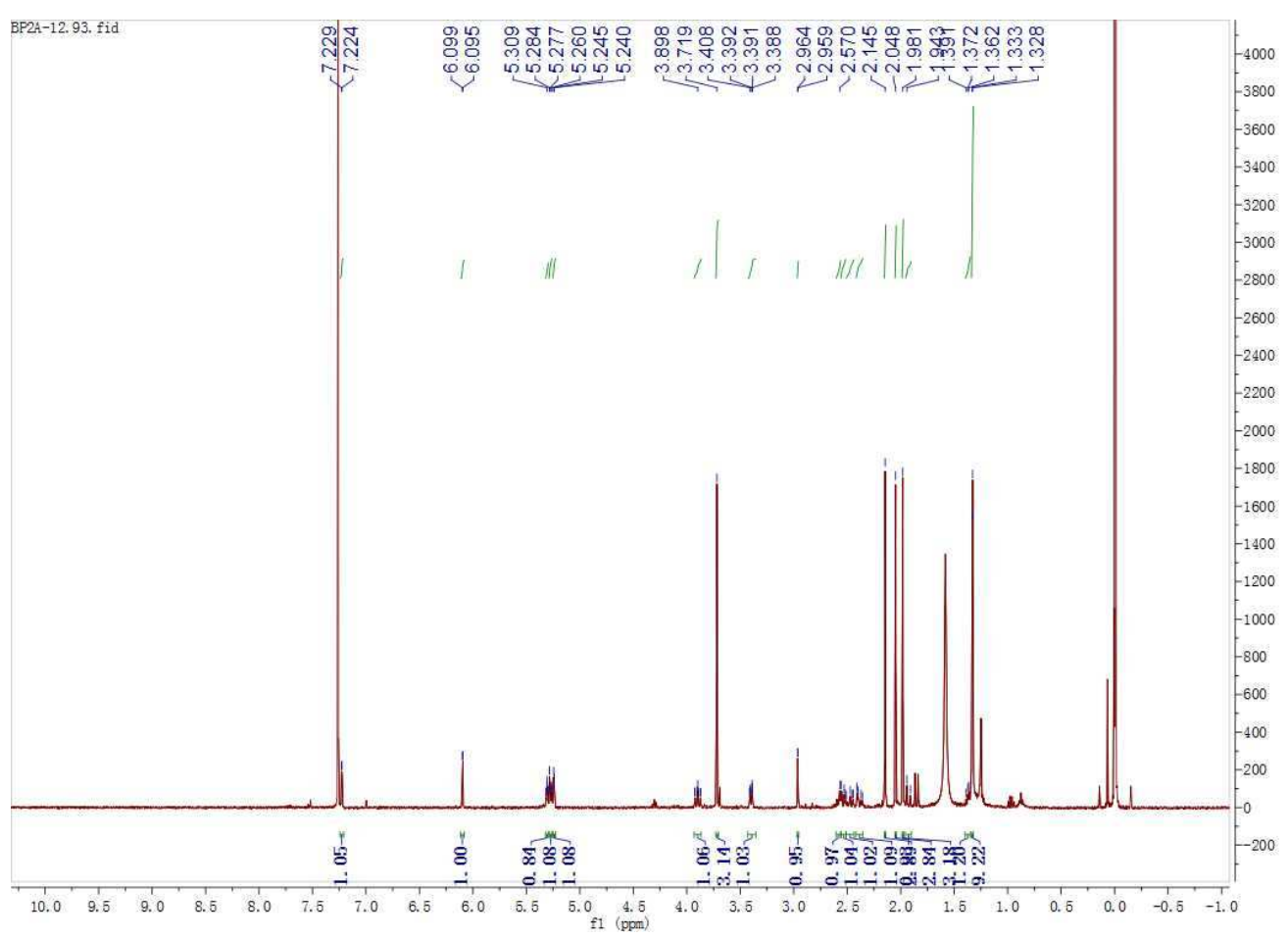

S57. The ${ }^{1} \mathrm{H}$ NMR (400 MHz, $\mathrm{CDCl}_{3}$ ) Spectrum of compound 9

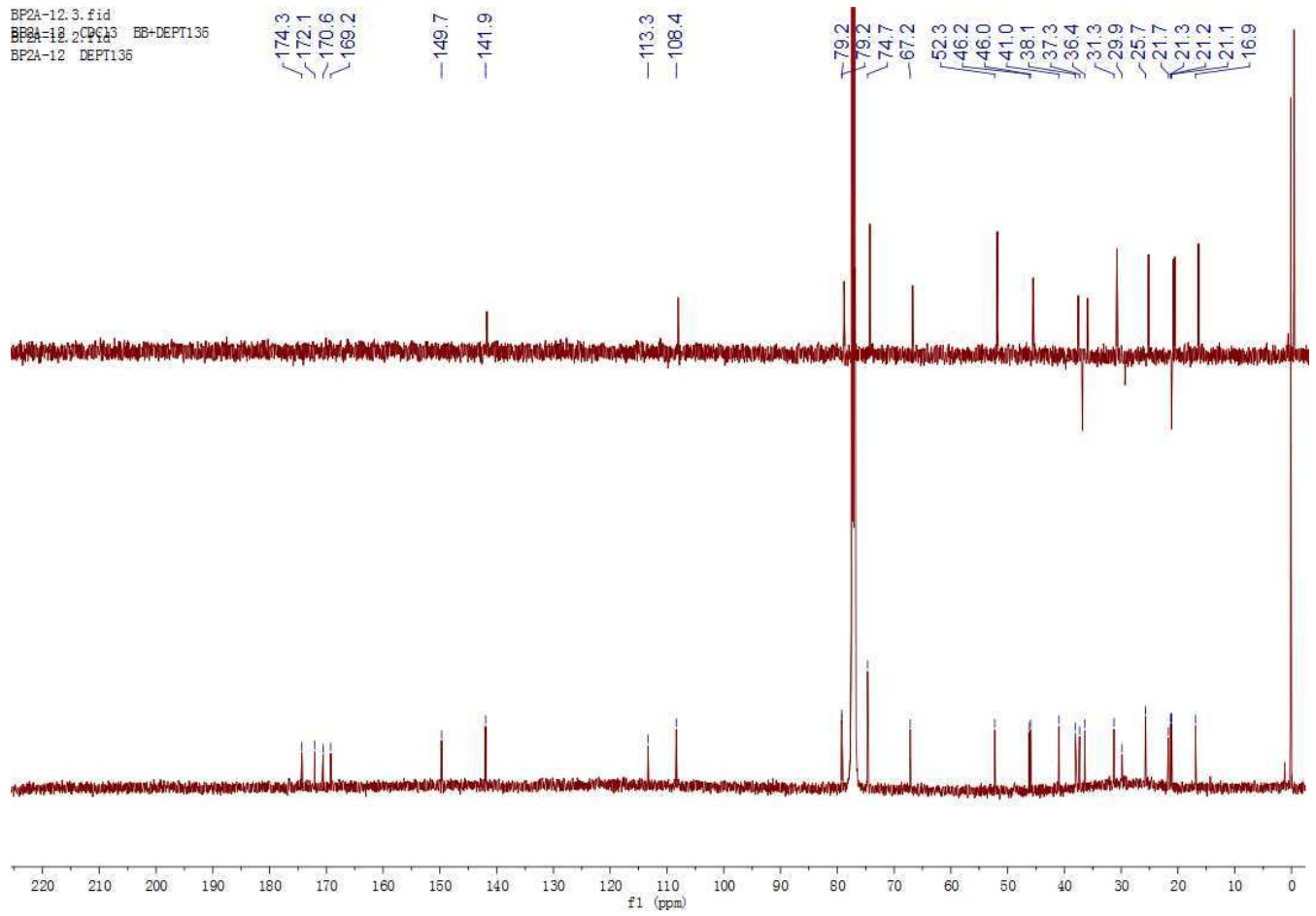

S58. The ${ }^{13} \mathrm{C}$ NMR (100 MHz, $\left.\mathrm{CDCl}_{3}\right)$ Spectrum of compound 9 


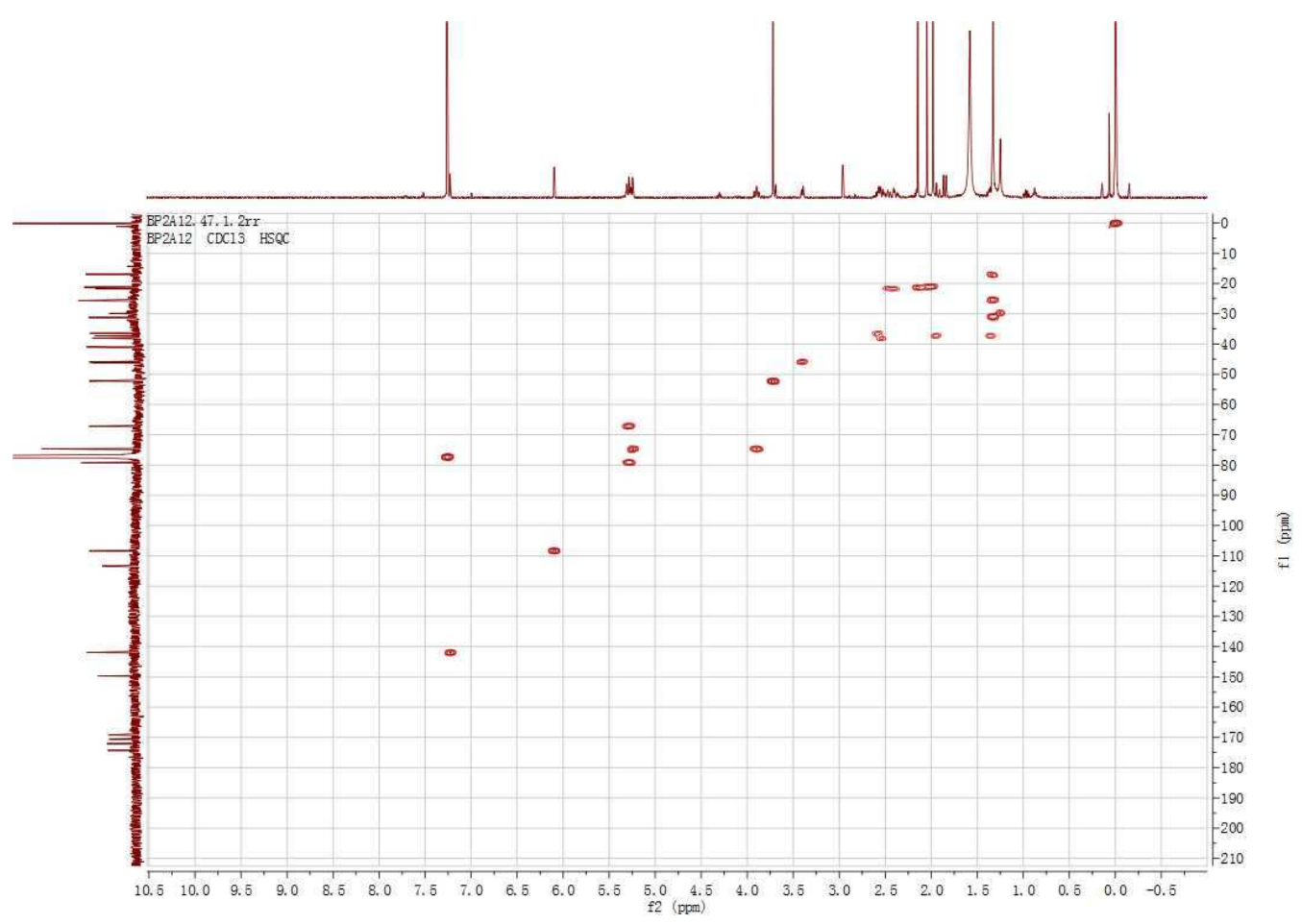

S59. The ${ }^{1} \mathrm{H}-{ }^{13} \mathrm{C}$ HMQC (400 MHz, $\mathrm{CDCl}_{3}$ ) Spectrum of compound 9

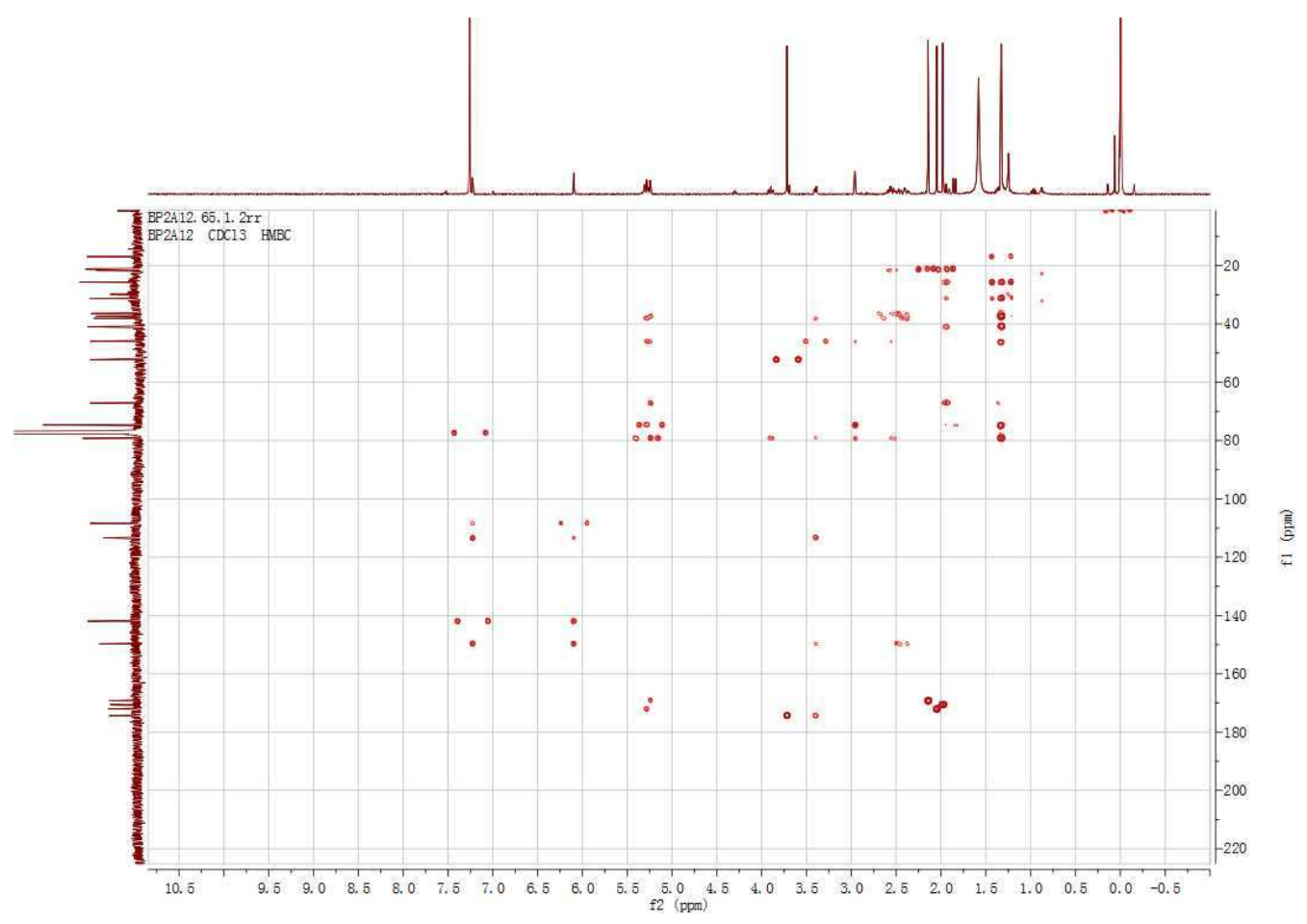

S60. The ${ }^{1} \mathrm{H}-{ }^{13} \mathrm{C}$ HMBC (400 MHz, $\mathrm{CDCl}_{3}$ ) Spectrum of compound 9 


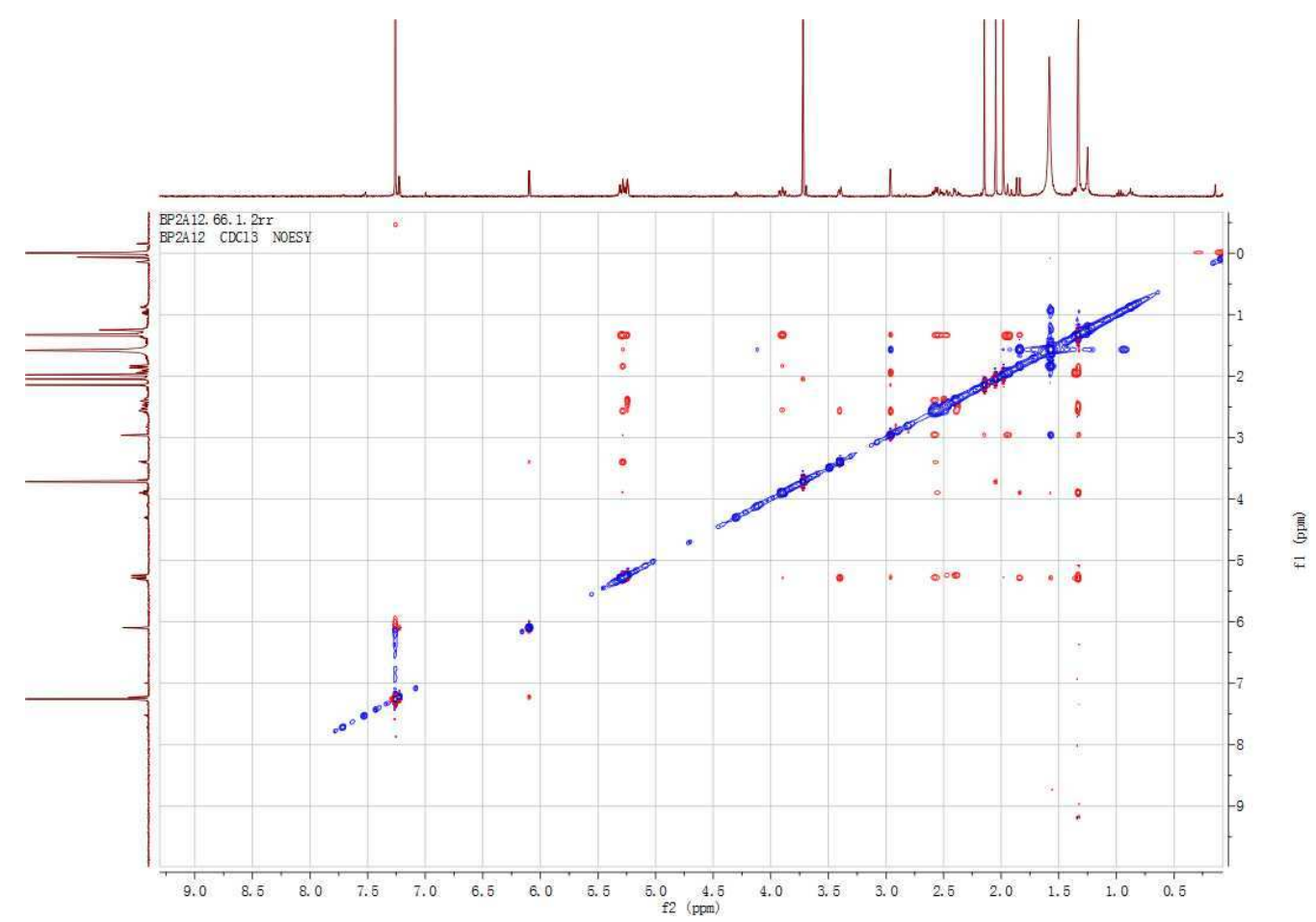

S61. The ${ }^{1} \mathrm{H}-{ }^{1} \mathrm{H}$ ROESY (400 MHz, $\mathrm{CDCl}_{3}$ ) Spectrum of compound 9

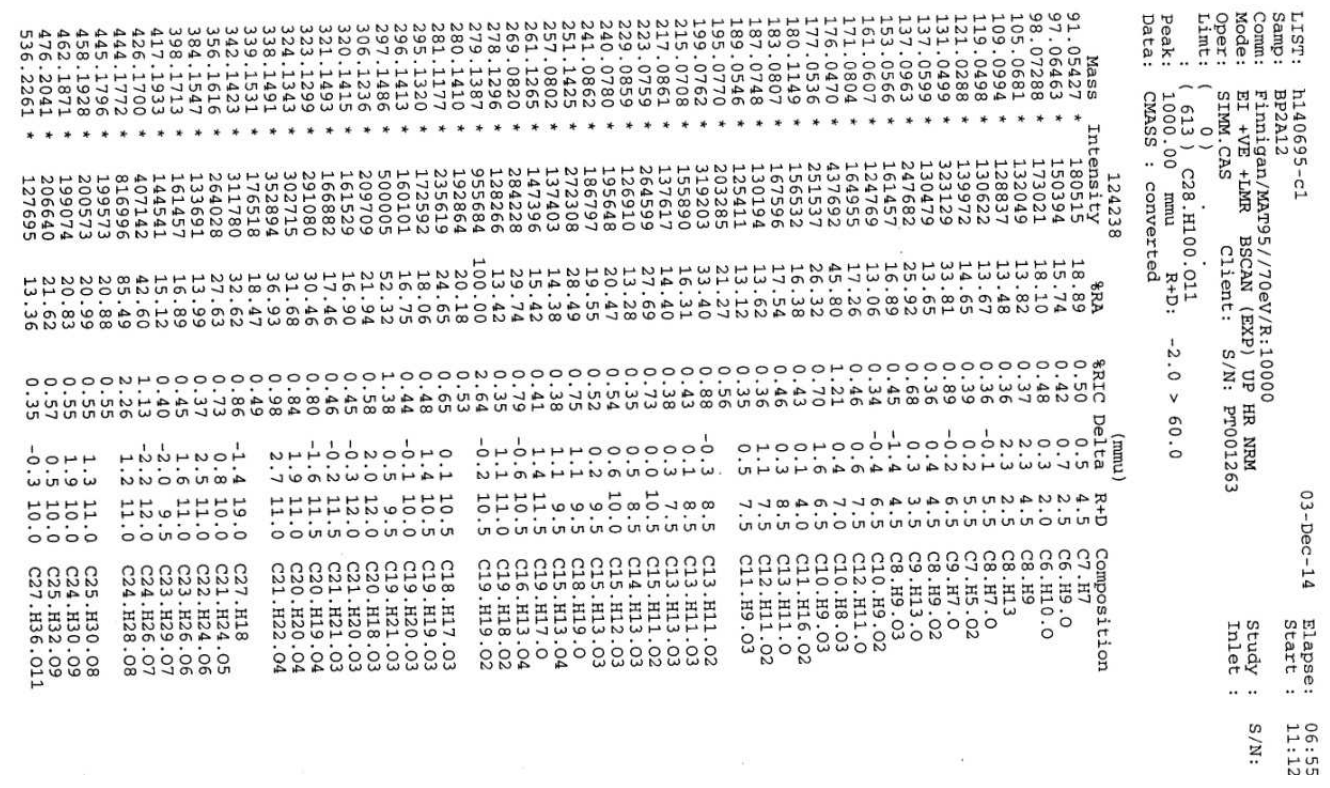

S62. The HR-EI-MS spectrum of compound 9 


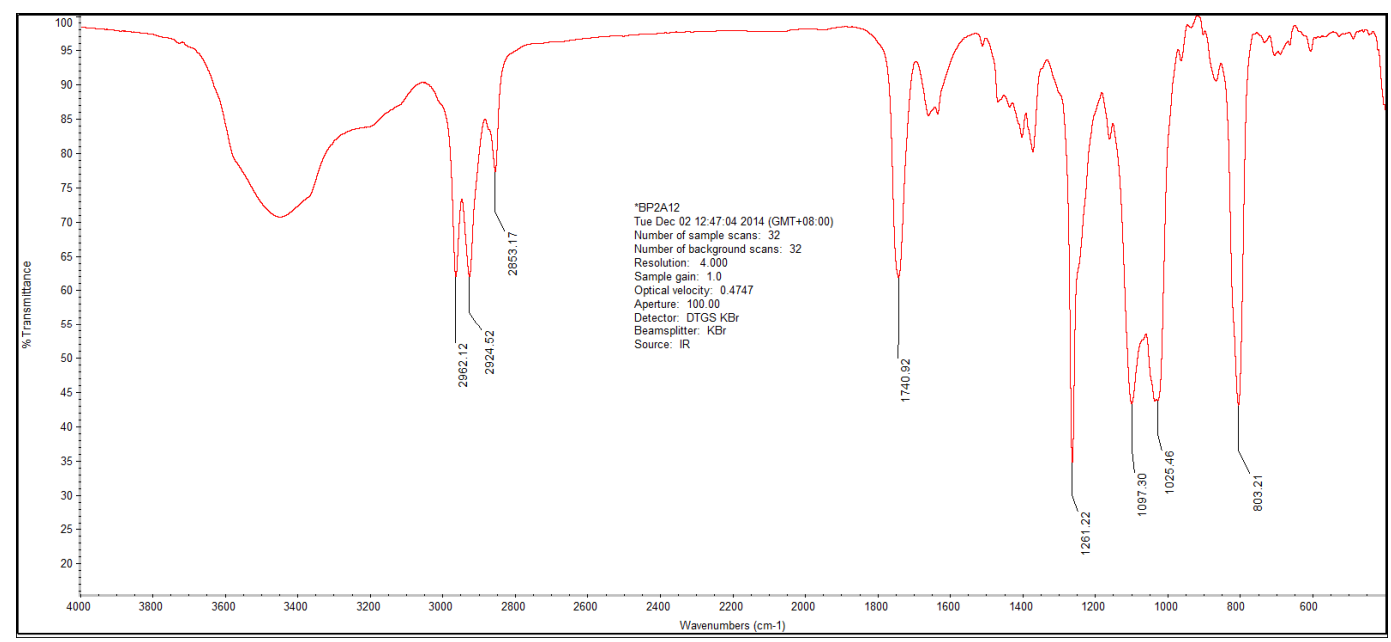

S63. The IR Spectrum of compound 9

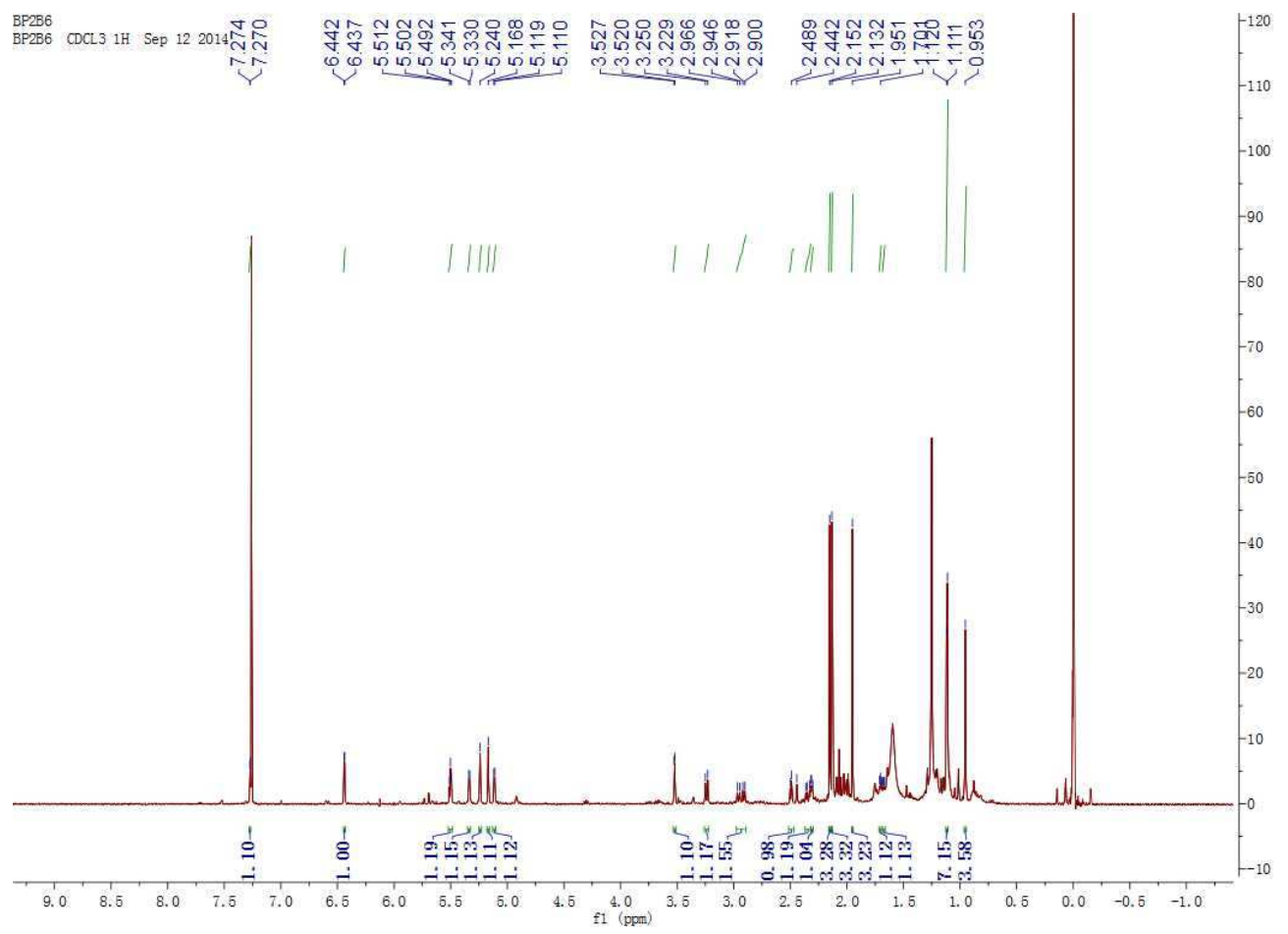

S64. The ${ }^{1} \mathrm{H}$ NMR (400 MHz, $\mathrm{CDCl}_{3}$ ) Spectrum of compound $\mathbf{1 0}$ 


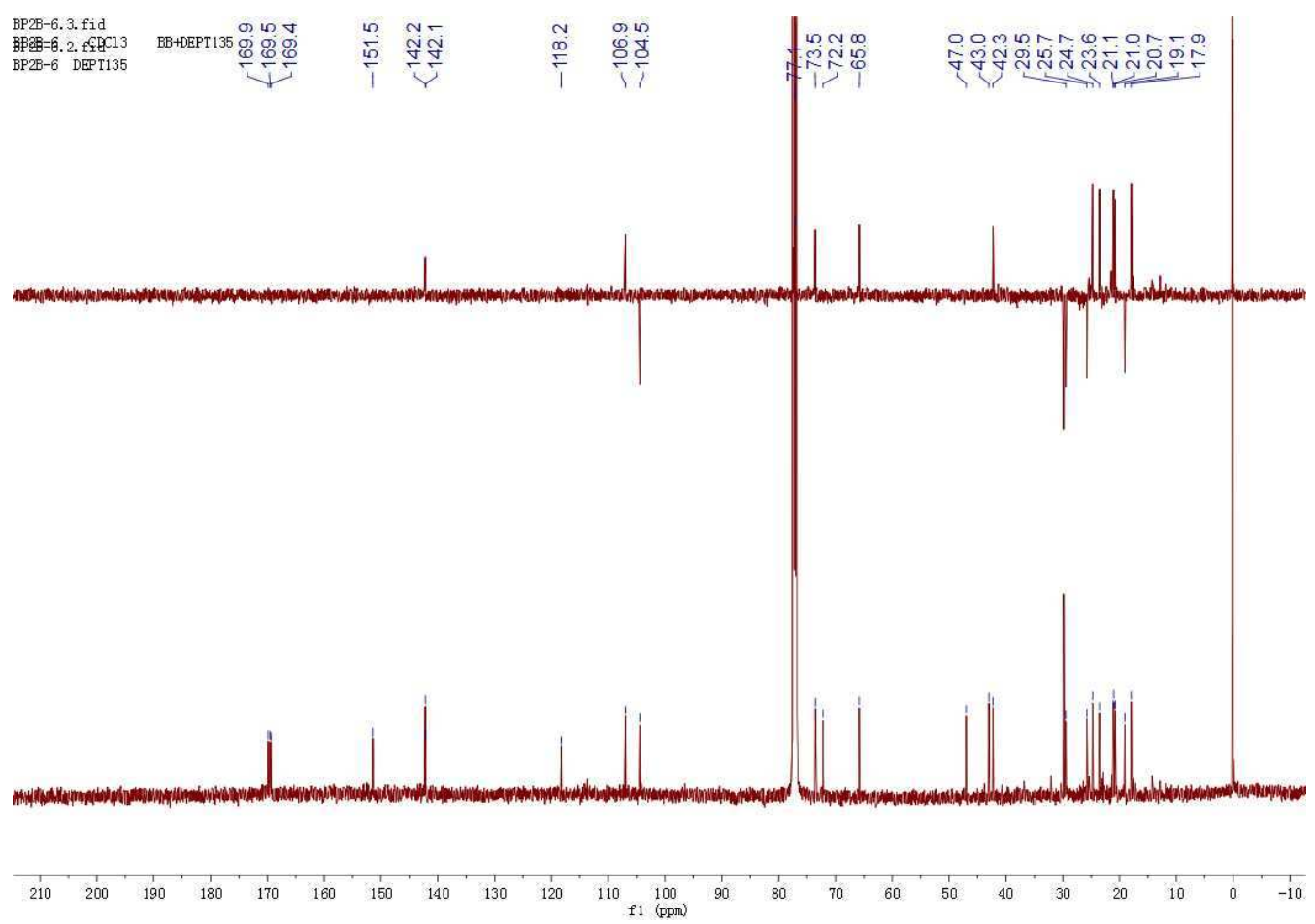

S65. The ${ }^{13} \mathrm{C}$ NMR (100 MHz, $\mathrm{CDCl}_{3}$ ) Spectrum of compound $\mathbf{1 0}$

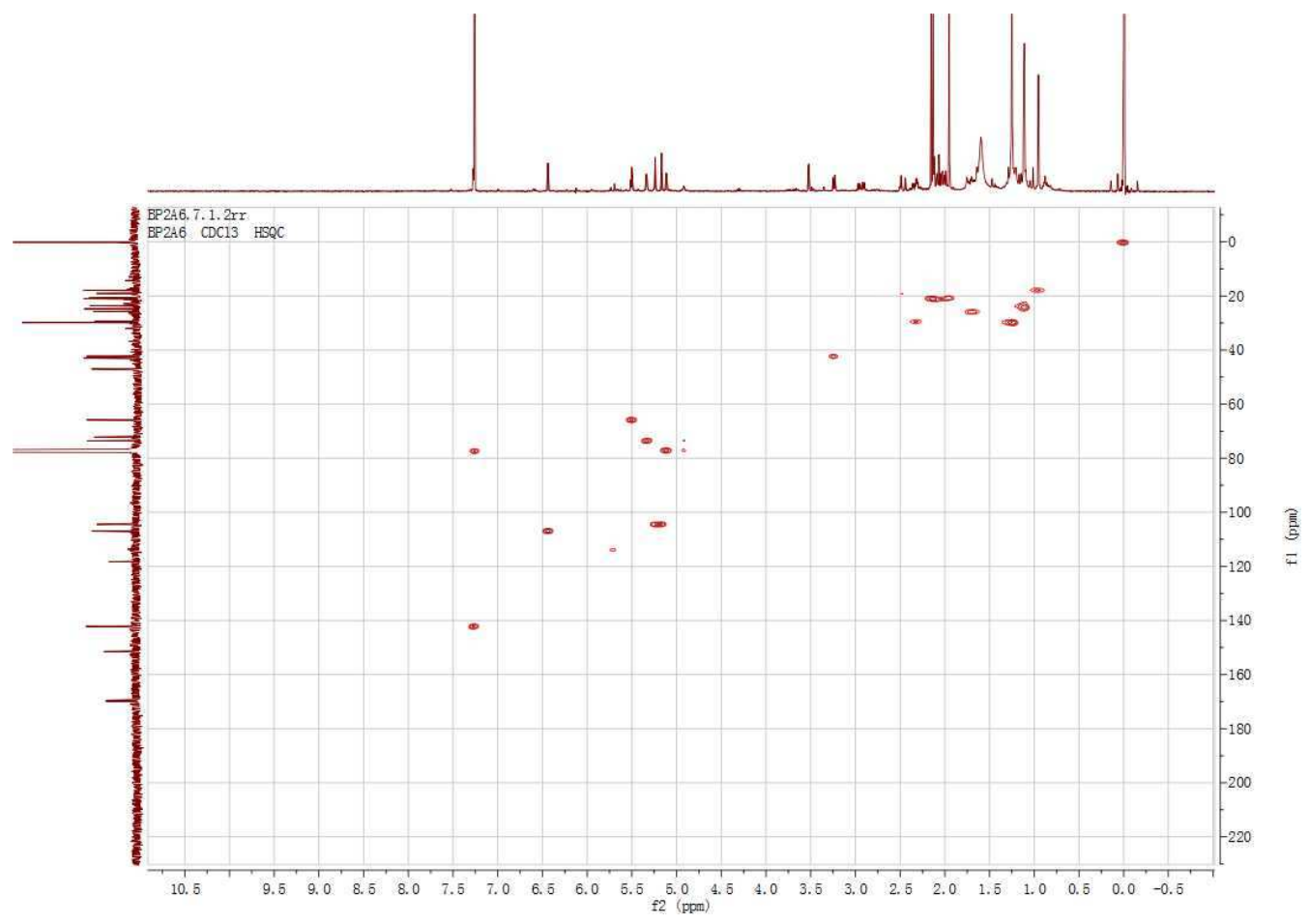

S66. The ${ }^{1} \mathrm{H}-{ }^{13} \mathrm{C} \mathrm{HMQC}\left(400 \mathrm{MHz}, \mathrm{CDCl}_{3}\right.$ ) Spectrum of compound 10 


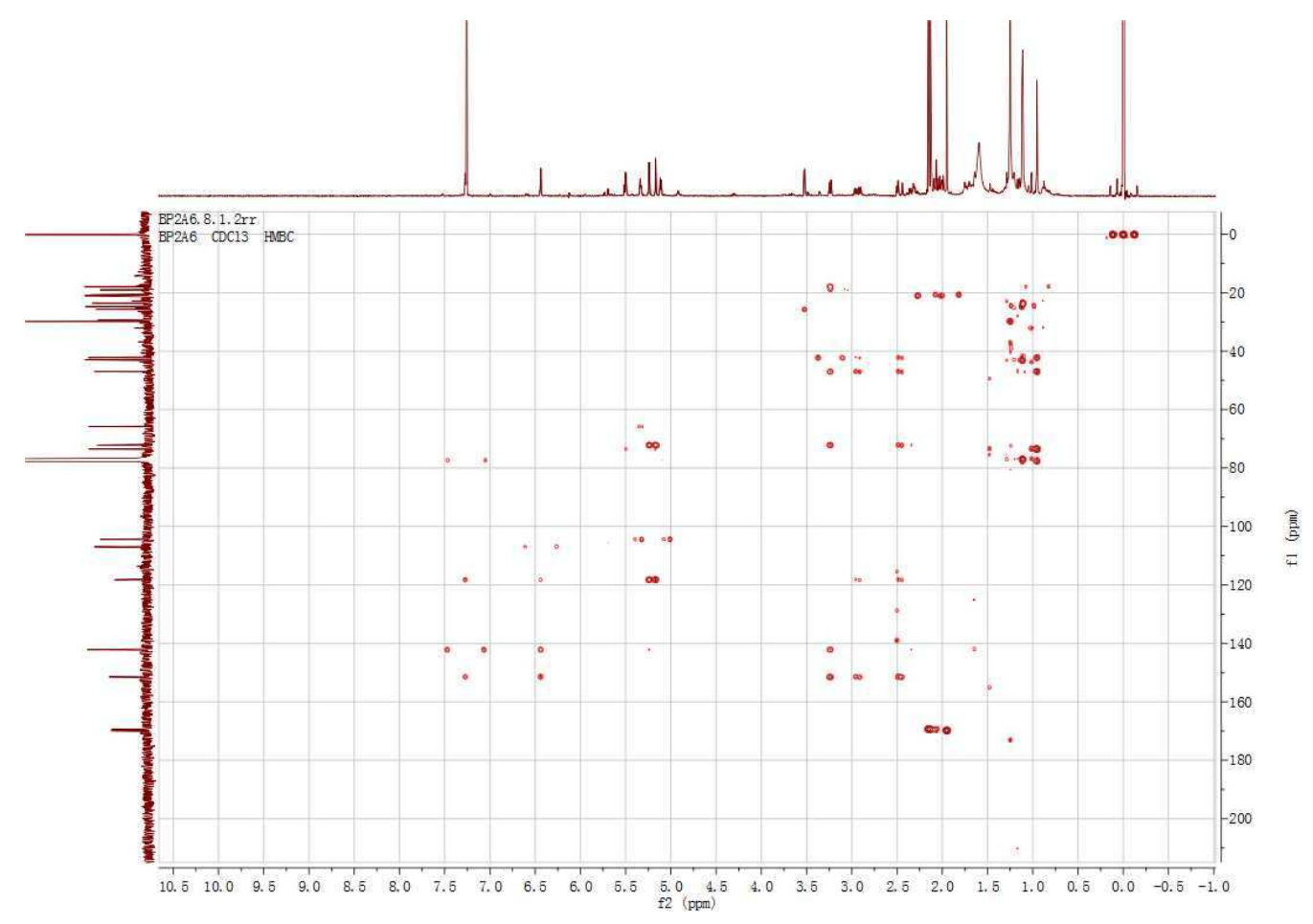

S67. The ${ }^{1} \mathrm{H}-{ }^{13} \mathrm{C}$ HMBC (400 MHz, $\mathrm{CDCl}_{3}$ ) Spectrum of compound 10

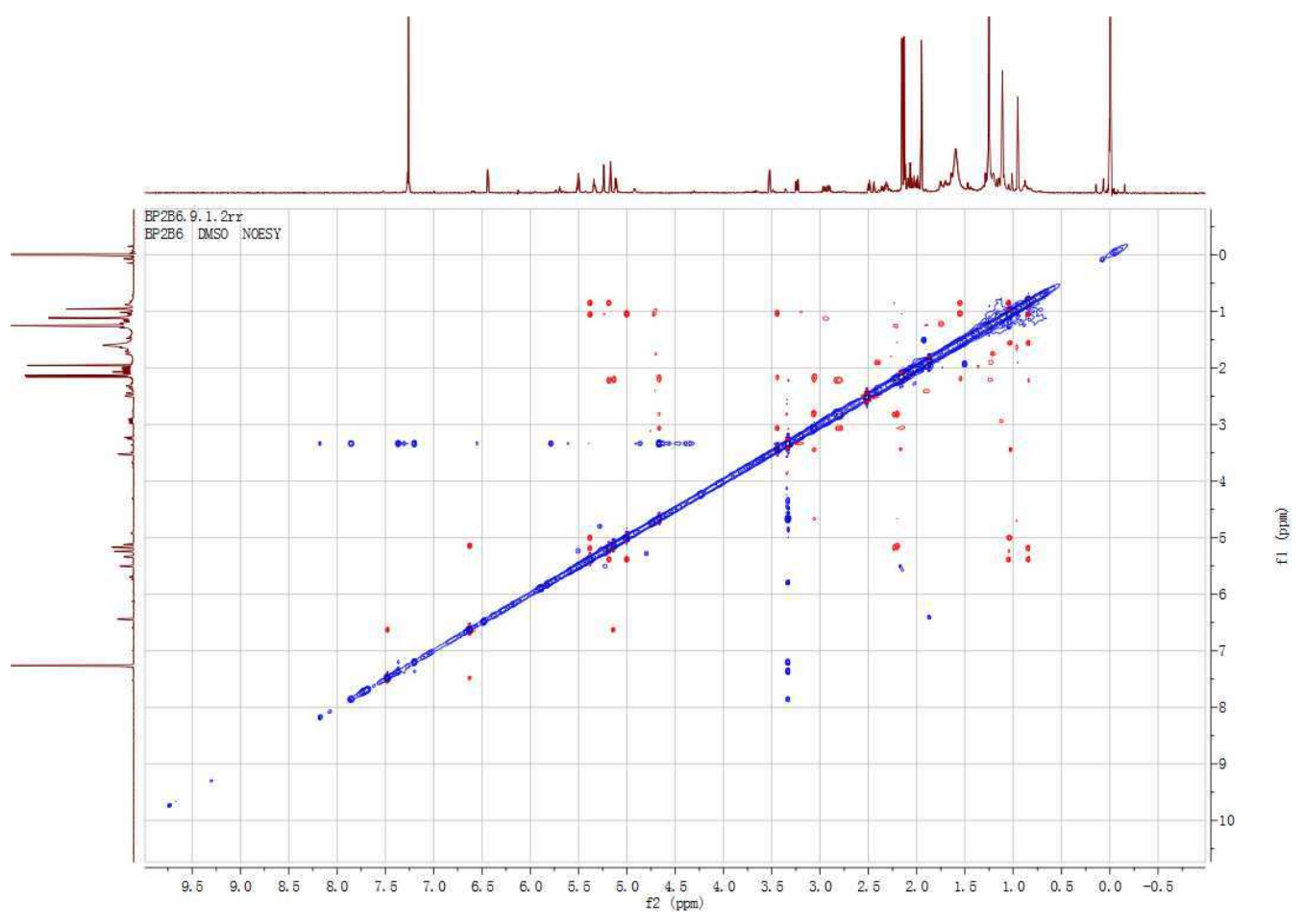

S68. The ${ }^{1} \mathrm{H}-{ }^{1} \mathrm{H}$ ROESY (400 MHz, $\mathrm{CDCl}_{3}$ ) Spectrum of compound 10 


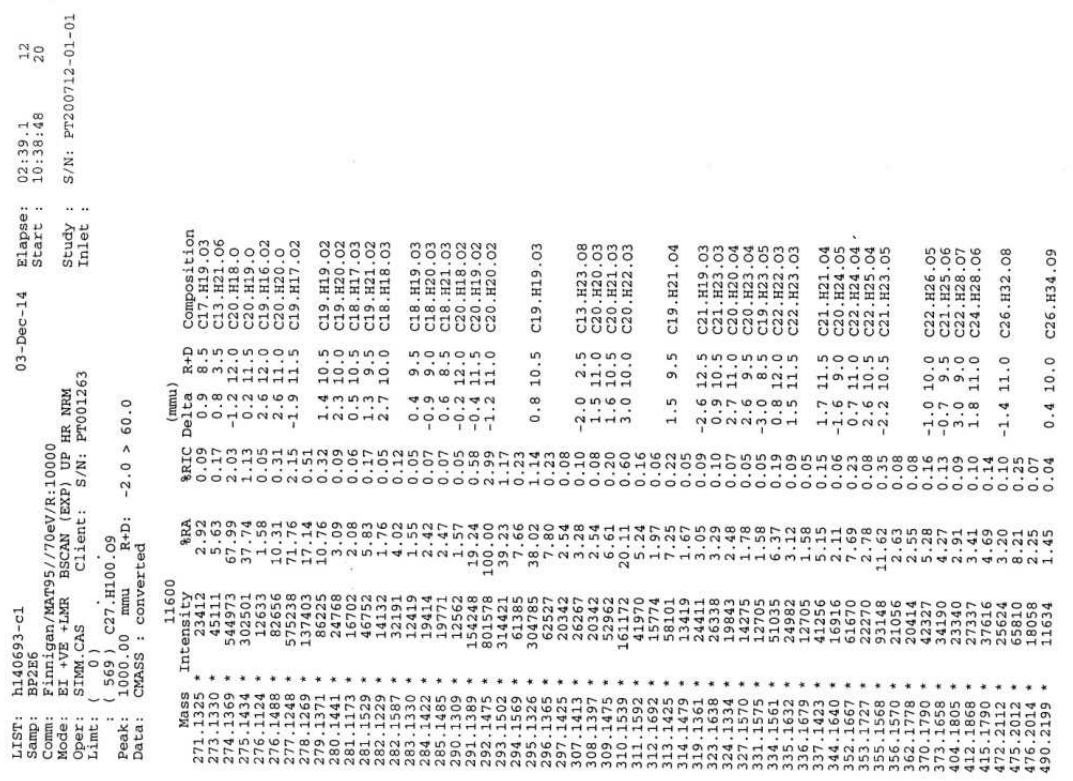

S69. The HR-EI-MS spectrum of compound $\mathbf{1 0}$

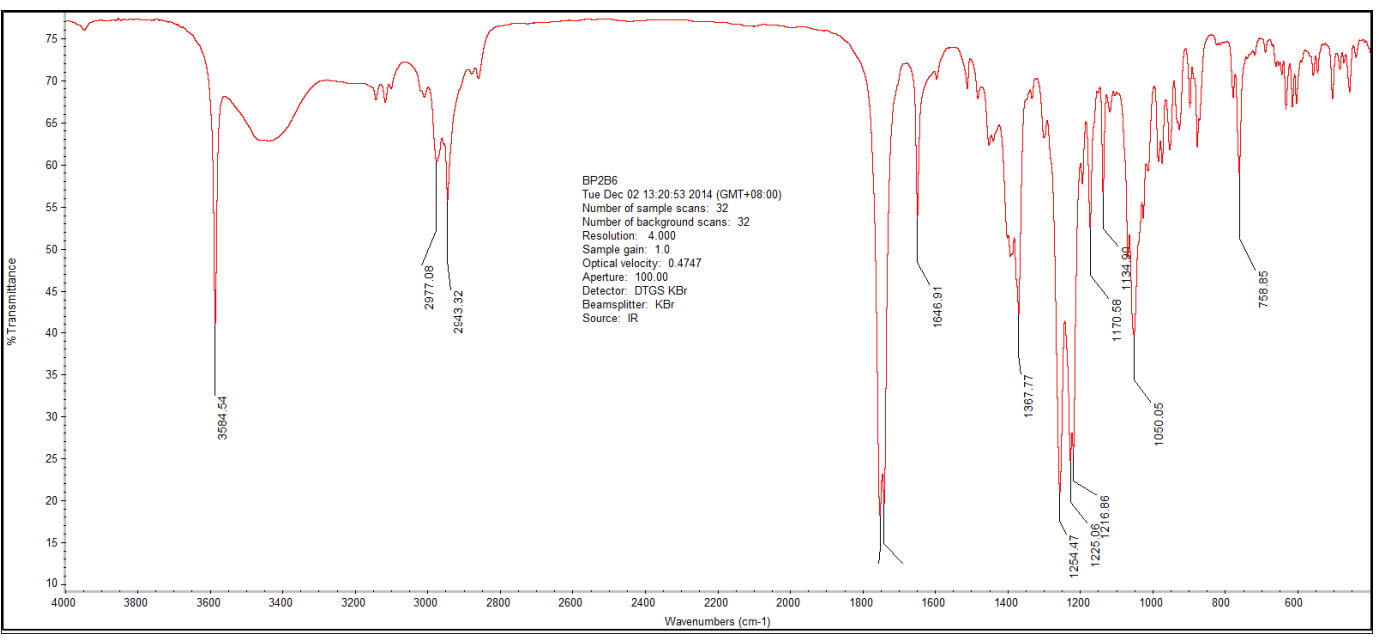

S70. The IR Spectrum of compound $\mathbf{1 0}$ 
Table S1. Neuroprotective Effects of Selected Compounds isolated from C. bonduc against $\mathrm{H}_{2} \mathrm{O}_{2}$ Induced Neurotoxicity in SH-SY5Y Cells

\begin{tabular}{|c|c|c|}
\hline \multirow{2}{*}{ Compd. } & Cell viability ${ }^{\mathrm{a}}$ (\% compared with model group) \\
\cline { 2 - 3 } & $1 \mu \mathrm{M}$ & $10 \mu \mathrm{M}$ \\
\hline $\mathbf{2}$ & $/{ }^{\mathrm{b}}$ & $/$ \\
\hline $\mathbf{7}$ & $/$ & $/$ \\
\hline $\mathbf{8}$ & $/$ & $/$ \\
\hline $\mathbf{1 1}$ & $/$ & $/$ \\
\hline $\mathbf{1 2}$ & $/$ & $/$ \\
\hline $\mathbf{1 3}$ & $/$ & $/$ \\
\hline $\mathbf{1 4}$ & $/$ & $/$ \\
\hline $\mathbf{1 6}$ & $/$ & $45.36^{* * * *}(100 \mu \mathrm{M})$ \\
\hline $\mathbf{1 8}$ & \multicolumn{2}{|c|}{$73.73^{* * * *}(300 \mu \mathrm{M})$} \\
\hline $\mathrm{H}_{2} \mathrm{O}_{2}$ & \multicolumn{2}{|c|}{100.00} \\
\hline $\mathrm{NAC}$ & Control & \multicolumn{2}{|c|}{} \\
\hline
\end{tabular}

${ }^{a}$ The cell viability in control was taken as $100 \%$, and the average value of cell viability under $\mathrm{H}_{2} \mathrm{O}_{2}$ exposure was $45.36 \%$. The positive control is $N$-Acetyl-cysteine (NAC). ${ }^{\mathrm{b}}$ The / means not active. ${ }^{\mathrm{c}}$ The ${ }^{* * * * * * *}$ mean active. ${ }^{*} p<0.05,{ }^{* *} p<0.01,{ }^{* * *} p<0.001$ versus control group.

Table S2. Neuroprotective Effects of Selected Compounds isolated from C. bonduc against $\mathrm{A} \beta_{25-35}$ Induced Neurotoxicity in SH-SY5Y Cells

\begin{tabular}{|c|c|c|}
\hline \multirow{2}{*}{ Compd. } & Cell viability ${ }^{\mathrm{a}}$ (\% compared with model group) \\
\cline { 2 - 3 } & $1 \mu \mathrm{M}$ & $10 \mu \mathrm{M}$ \\
\hline $\mathbf{2}$ & $/{ }^{\mathrm{b}}$ & $/$ \\
\hline $\mathbf{7}$ & $/$ & $/$ \\
\hline $\mathbf{8}$ & $/$ & $/$ \\
\hline $\mathbf{1 1}$ & $/$ & $/$ \\
\hline $\mathbf{1 2}$ & $/$ & $/$ \\
\hline $\mathbf{1 3}$ & $/$ & $/$ \\
\hline $\mathbf{1 4}$ & $/$ & $/$ \\
\hline $\mathbf{1 6}$ & $/$ & $63.00^{* * *}$ \\
\hline $\mathbf{1 8}$ & \multicolumn{2}{|c|}{$29.68^{* * \mathrm{c}}(10 \mu \mathrm{M})$} \\
\hline $\mathrm{A} \beta_{25-35}$ & \multicolumn{2}{|c|}{100.00} \\
\hline EGCG & Control & \multicolumn{2}{|c|}{} \\
\hline
\end{tabular}

${ }^{a}$ The cell viability in control was taken as $100 \%$, and the average value of cell viability under $\mathrm{A} \beta_{25-35}$ exposure was $63.00 \%$. The positive control is epigallocatechin gallate (EGCG). ${ }^{\mathrm{b}}$ The / means not active. ${ }^{\mathrm{c}}$ The ${ }^{* * * * * * *}$ mean active. ${ }^{*} p<0.05,{ }^{* *} p<0.01,{ }^{* * *} p<0.001$ versus control group. 
Table S3. Neuroprotective Effects of Selected Compounds isolated from C. bonduc against OGD-Induced Neurotoxicity in SH-SY5Y Cells

\begin{tabular}{|c|c|c|}
\hline \multirow{2}{*}{ Compd. } & Cell viability ${ }^{\mathrm{a}}$ (\% compared with model group) \\
\cline { 2 - 3 } & $1 \mu \mathrm{M}$ & $10 \mu \mathrm{M}$ \\
\hline $\mathbf{2}$ & $/{ }^{\mathrm{b}}$ & $/$ \\
\hline $\mathbf{7}$ & $/$ & $/$ \\
\hline $\mathbf{8}$ & $/$ & $/$ \\
\hline $\mathbf{1 1}$ & $/$ & $/$ \\
\hline $\mathbf{1 2}$ & $/$ & $/$ \\
\hline $\mathbf{1 3}$ & $/$ & $/$ \\
\hline $\mathbf{1 4}$ & $/$ & $/$ \\
\hline $\mathbf{1 6}$ & $/ 2$ & \\
\hline $\mathbf{1 8}$ & \multicolumn{2}{|c|}{$51.21^{* *_{c}}$} \\
\hline OGD & \multicolumn{2}{|c|}{100.00} \\
\hline Control & \multicolumn{2}{|c}{} \\
\hline
\end{tabular}

${ }^{\mathrm{a}}$ The OGD untreated group, as normal group, control was set to $100 \%$, and the average value of cell viability under OGD exposure was $51.21 \%$. ${ }^{\mathrm{b}}$ The / means not active. ${ }^{\mathrm{c}}$ The ${ }^{* * * * * * *}$ means active. ${ }^{*} p<0.05,{ }^{* *} p<0.01,{ }^{* * *} p<0.001$ versus control group. 